PEDRO AUGUSTO PARENTE DIAS

\title{
ENTREGAS NOTURNAS NO MUNICÍPIO DE SÃO PAULO: PERCEPÇÕES DOS MOTORISTAS E RECEBEDORES
}

Dissertação apresentada à Escola Politécnica da Universidade de São Paulo para obtenção do título de mestre em Ciências.

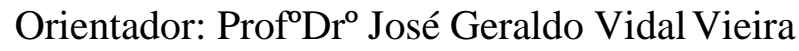

São Paulo

2016 
PEDRO AUGUSTO PARENTE DIAS

\section{ENTREGAS NOTURNAS NO MUNICÍPIO DE SÃO PAULO: PERCEPÇÕES DOS MOTORISTAS E RECEBEDORES}

Dissertação apresentada à Escola Politécnica da Universidade de São Paulo para obtenção do título de mestre em Ciências.

Área de Concentração: Engenharia de Sistemas Logísticos

Orientador: Prof ${ }^{\circ} \operatorname{Dr}^{\circ}$ José Geraldo Vidal Vieira

São Paulo

2016 
Este exemplar foi revisado e corrigido em relaçăo à versăo original, sob responsabilidade única do autor e com a anuência de seu orientador.

Såo Paulo, de de

Assinatura do autor:

Assinatura do orientador:

Catalogação-na-publicação

Dias, Pedro

Entregas noturnas no municipio de Săo Paulo: percepções de motoristas e recebedores / P. Dias -- versão corr. -- Săo Paulo, 2016.

$109 \mathrm{p}$.

Dissertação (Mestrado) - Escola Politécnica da Universidade de Săo Paulo. Departamento de Engenharia de Produção.

1.Logística 2.Transporte de carga 3.Entregas urbanas I.Universidade de Săo Paulo. Escola Politécnica. Departamento de Engenharia de Produçăo II.t. 


\section{RESUMO}

As pesquisas para o desenvolvimento de uma cidade mais sustentável, com menos trânsito e mais qualidade de vida, apontam a necessidade de elaboração de políticas voltadas para o transporte de carga. As entregas urbanas de carga sendo feitas no período noturno pode ajudar a melhorar o trânsito da cidade, e evitar acidentes com ciclistas, pedestres, ônibus e carros. Ao mesmo tempo, entregar mercadorias a noite pode ser vantajoso tanto para os varejistas quanto para os transportadores. Da perspectiva dos varejistas, pode haver mais agilidade em conferir e armazenar mercadorias, melhora do nível de atendimento ao cliente, e mais certeza quanto à pontualidade do horário da chegada do caminhão. Quanto aos transportadores, o tempo de rota pode diminuir, assim como tempo para buscar uma vaga para estacionar; as filas de caminhões podem diminuir, oferecendo mais eficiência ao roteiro de entregas. Entretanto, alguns problemas podem surgir ao executar os descarregamentos noturnos, relacionados à emissão de ruídos e ao risco de assaltos. O objetivo desta pesquisa é assinalar os principais aspectos que influenciam na eficiência das entregas noturnas no âmbito operacional, e identificar quais são os problemas relacionados à execução das entregas noturnas. Para cumprir estes objetivos foi aplicado um questionário a 100 motoristas, e outro questionário a 84 varejistas que realizam operações com entregas/recebimento de mercadorias no período noturno. A partir destes dados, análises estatísticas foram feitas para assinalar quais variáveis de análise estão mais associadas à escolha por executar as atividades de frete no período noturno. Os resultados mostraram que os ruídos são mais críticos para a tomada da decisão do horário de entrega, para os varejistas. Quanto aos resultados atrelados à eficiência logística, a vantagem em fazer entregas noturnas está na maior agilidade para conferir e armazenar as mercadorias e maior assertividade quanto ao horário de entrega, devido às condições do trânsito e da facilidade em estacionar o veículo para efetuar o descarregamento. 


\begin{abstract}
The findings of the researches for a more sustainable city, with less traffic and better quality of life, point to the need of new policies for the transport of cargo. Urban overnight deliveries can improve the traffic of city and prevent accidents involving cyclists, pedestrians, buses and cars. At the same time, overnight deliveries might be favorable, both for retailers and drivers. From the perspective of retailers, overnight deliveries may be more efficient in checking and storing goods, more punctual and improve customer service level. For drivers, time route and time to find a place to park may decrease; truck queues may be reduced, which offers more efficiency to the delivery route. However, some problems may arise when performing the night freight, regarding to its noise and the risk of robbery. The objective of this research is to verify the main aspects that maximize the efficiency of night deliveries in the operational context and identify the night freight problems. In order to meet these objectives, a questionnaire was applied to 100 drivers, and another questionnaire to 84 retailers. Statistical methods were used to make sure the noises as the most critical aspects of the night deliveries, for retailers. As for the results related to logistic effectiveness, the advantage of making overnight delivery is the agility to check and store the goods and the accuracy on the delivery schedule, due to traffic conditions, and the ease to park the vehicle to perform the download. In addition, multivariate analysis method combines the quality of customer service with the punctuality of the truck and the agility in check and store goods.
\end{abstract}




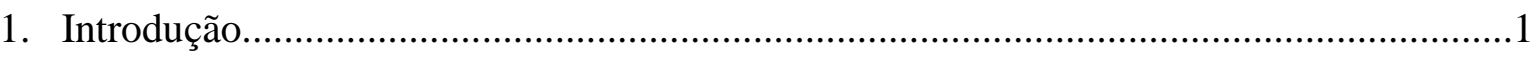

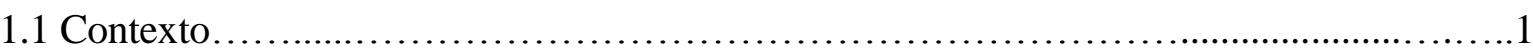

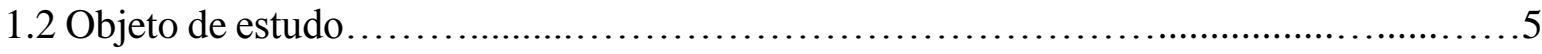

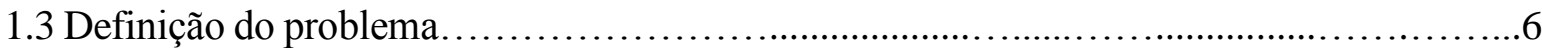

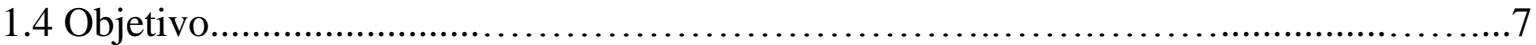

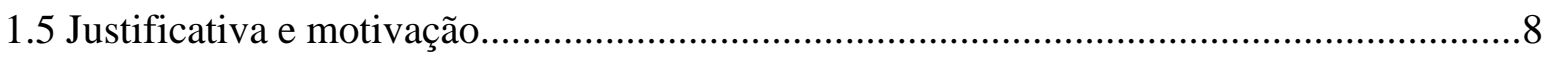

1.6 Escopo da dissertação.......................................................... 10

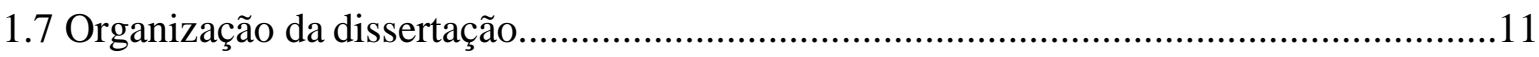

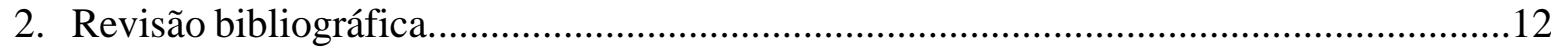

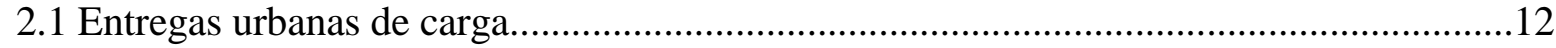

2.1.1 Qualidade de níveis de serviço para entregas urbanas de carga................................. 14

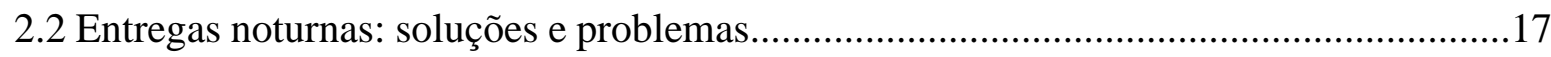

2.2.1 Motivações para a implantação de entregas noturnas: uma visão histórica....................17

2.2.2 Stakeholders e seu papel nas entregas noturnas.........................................................19

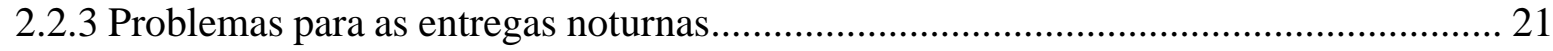

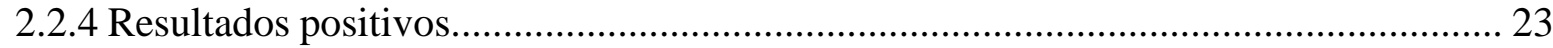

2.2.5 Resumo dos principais aspectos dos projetos de entregas noturnas............................25

2.3 Comparação entre entregas diurnas e noturnas........................................................27

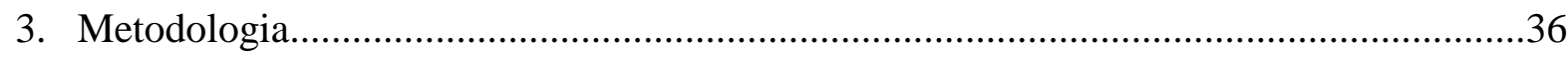

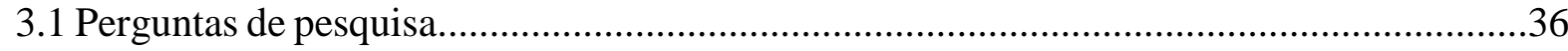

3.2 Projeto-piloto de enteregas noturnas no município de São Paulo....................................38

3.3 Desenvolvimento e aplicações de pesquisa tipo levantamento de dados em projetos de

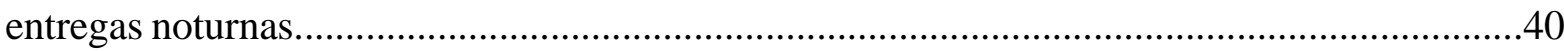

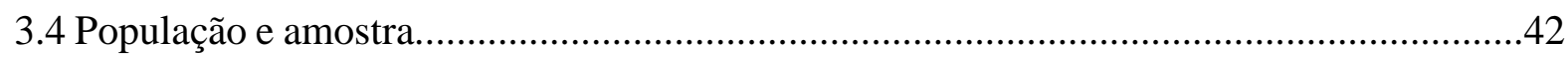

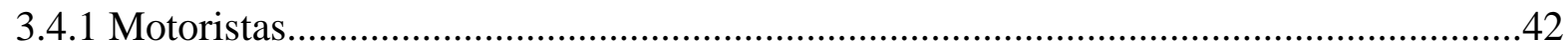

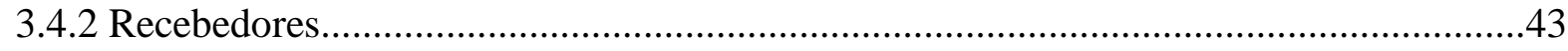

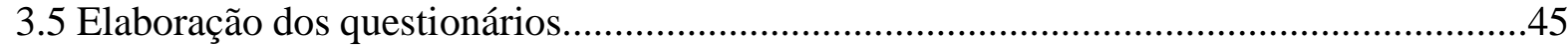

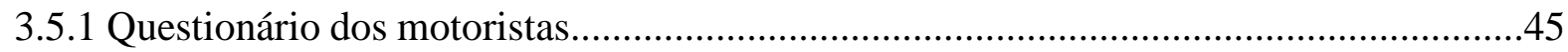

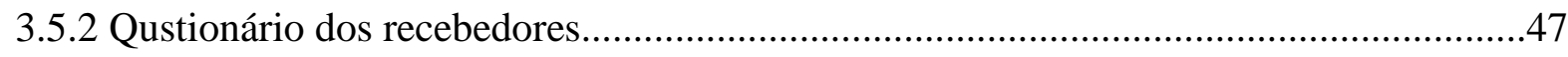

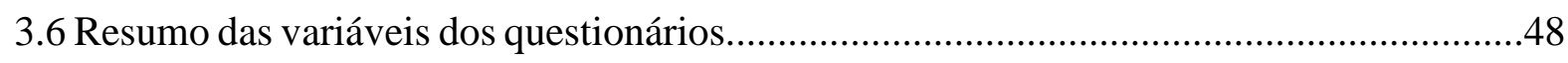

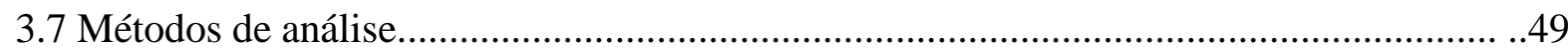


4. Apresentação e análise dos dados .51

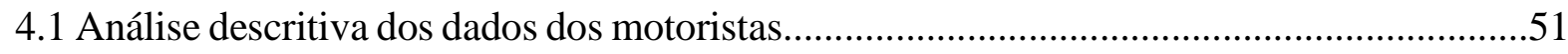

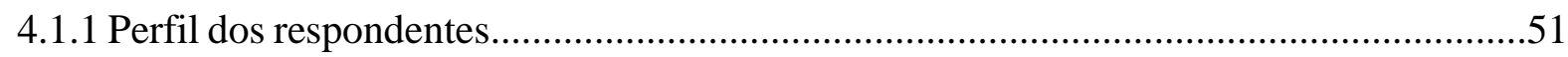

4.1.2 Caracterização do trabalho e das entregas.....................................................................52

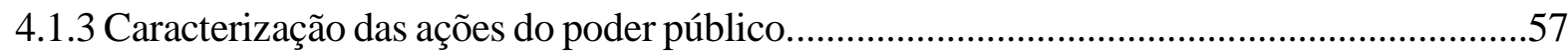

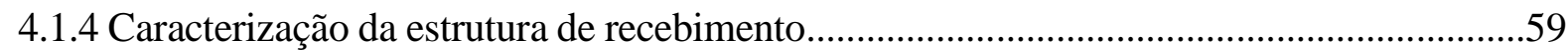

4.1.5 Identificação dos problemas para as entregas noturnas...................................................62

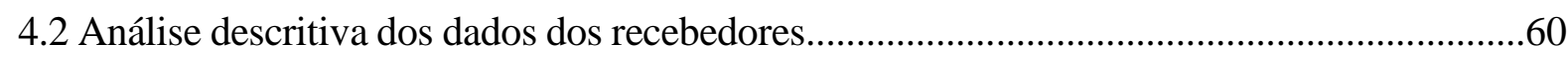

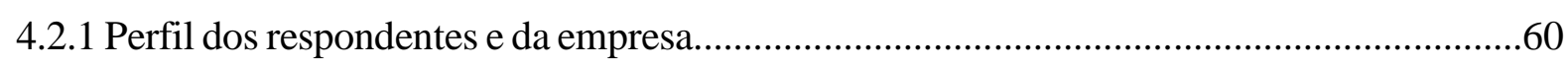

4.2.2 Caracterização da organização da loja...............................................................................63

4.2.3 Caracterização das ações do poder público...........................................................................64

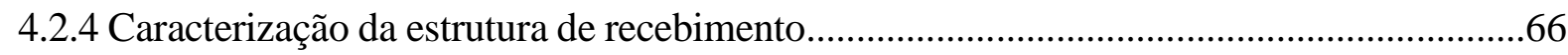

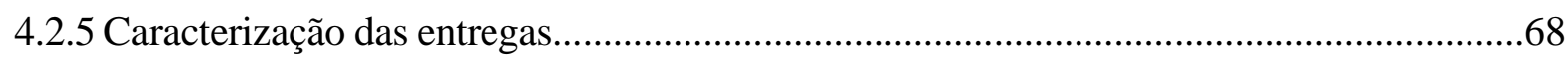

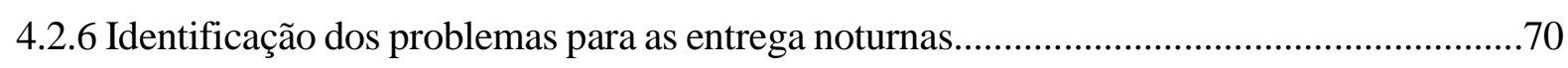

4.3 Análise de correspondência aplicada à percepação de entregas diurnas versus

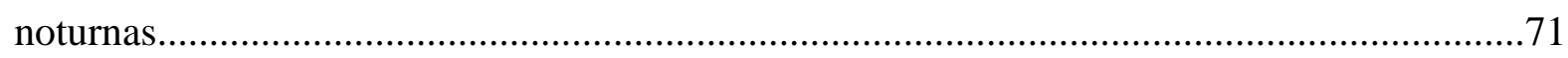

4.3.1 Associação entre a preferência do horário de entrega e os problemas...........................71

4.3.2 Associação entre a preferência do horário de entrega e a eficiência logística.................75

4.4 Análise comparativa entre o programa de entregas noturnas de São Paulo com os outros programas de entregas noturnas em outras cidades do mundo..............................................76

4.4.1 Motivações para a implantação de um programa de entregas noturnas...............................76

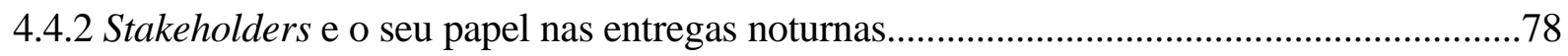

4.4.3 Resultados dos projetos pioneiros de entregas noturnas................................................78

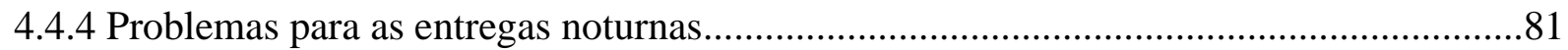

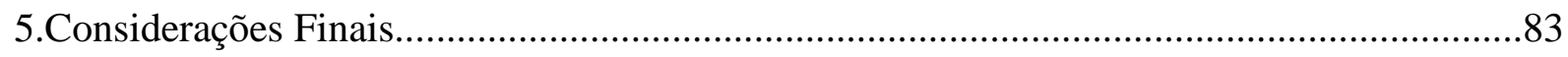

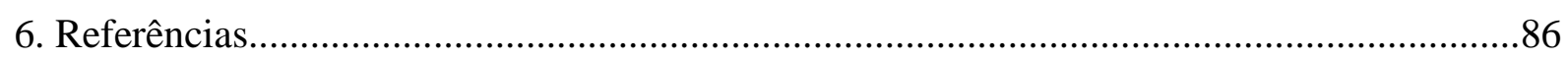

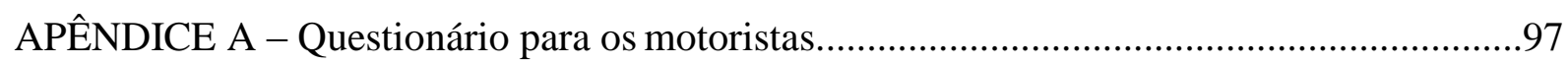

APÊNDICE B - Questionário para os recebedores.............................................................99 


\title{
1. Introdução
}

\subsection{Contexto}

Grandes centros urbanos do mundo inteiro compartilham um problema em comum: o tráfego urbano. O excesso de veículos, principalmente nos horários de pico, constitui uma realidade que vem sendo enfrentada pelo poder público através do estabelecimento de leis e regulamentações com o objetivo de melhorar, principalmente, a mobilidade urbana. Este é também um problema para o transporte eficiente de carga urbana, que tem desafiado as empresas que estão envolvidas nesta tarefa de entregas de mercadorias. Neste sentido, pesquisadores e autoridades têm se concentrado em analisar a situação do trânsito e a viabilidade de transportar carga de forma a contribuir para o menor índice de externalidades (VASCONCELOS, 2005), ou seja, menos ruído, menos acidentes, menos poluição. Certamente, tais pesquisas poderão contribuir para a elaboração e execução de políticas efetivas junto ao poder público, já que o transporte de carga influencia nas condições de mobilidade urbana das cidades (RUSSO; COMI, 2011). Segundo consta no Plano Diretor de Mobilidade do Ministério dos Transportes (2015),

\begin{abstract}
A mobilidade nas cidades é fator preponderante na qualidade de vida dos cidadãos. $\mathrm{O}$ modelo de circulação de pessoas e cargas dentro do território urbano interfere no desenvolvimento do País, pois dele dependem a logística de distribuição de produtos, a saúde e a produtividade de sua população, entre outros.
\end{abstract}

Allen e Browne (2010) relatam os efeitos, em longo prazo, das políticas de transporte de carga aplicadas em grandes cidades, com foco no caso de Londres. Os autores enfatizam a importância do transporte nas interações entre a sociedade, o meio ambiente e o circuito comercial. Os diversos aspectos abordados demonstram o quão complexo se tornou o papel do transporte de carga para atender às diversas demandas da sociedade atualmente.

As políticas de transporte de carga se relacionam aos efeitos de um trânsito caótico, e essas repercussões negativas atingem diversas esferas do meio socioambiental e a saúde da população. Em termos de meio ambiente pode-se citar o aumento de emissões de carbono; a intensificação do efeito estufa; a formação de ilhas de calor; e a redução do abastecimento de 
água (CERVERO, 2012). No quesito relacionado à saúde da população, entre as doenças que podem ser agravadas pelos congestionamentos estão o estresse emocional, doenças cardiovasculares incluindo o câncer de pulmão, mortalidade precoce, sedentarismo (SALDIVA, 2014). Além destes problemas, o trânsito ainda torna ineficiente o sistema logístico de muitas empresas que atuam no meio urbano. Essa enumeração de fatores enfatiza a necessidade de mudanças de paradigma no planejamento de políticas voltadas à melhoria do tráfego.

Não só os sujeitos que compõe a cadeia logística, mas também o poder público, sociedade e meio ambiente são influenciados pelos mecanismos de coordenação da cadeia logística (DABLANC; MONTENON, 2015). Fatores como tamanho do caminhão, horário de carregamento e descarregamento, roteirização do veículo, entre outros, influenciam o comércio local, os residentes, os operadores de transporte público e os operadores de carga urbana (BALLATYNE; LINDHOLM; WHITEING, 2013). Regras mais rigorosas de trânsito são geralmente estabelecidas para as megacidades e impactam intensamente no dia a dia das pessoas, principalmente onde a demanda por bens e serviços é crescente, com o aumento de veículos e da população local. Megacidades, segundo a ONU, são cidades com 10 milhões de habitantes ou mais (UNRIC, 2015). O município de São Paulo, com uma população superior a 12.000.000 habitantes, segundo dados do IBGE, se enquadra neste conceito.

Meyer (2014) faz um panorama geral sobre as condições que agravam o trânsito de São Paulo. Com uma frota de mais de 7.500 .000 veículos e uma média de 200 mil carros vendidos por ano na cidade, o município de São Paulo historicamente privilegiou o deslocamento de pessoas através de automóveis particulares, fato notável que complica a situação do tráfego (ORTÚZAR; WILLUMSEN, 2011). O dinamismo econômico não só deste município, mas como da Região Metropolitana de São Paulo (RMSP) como um todo, contribui para um número elevado de deslocamentos: 43.700.000 diariamente, segundo dados da Pesquisa de Mobilidade do Metrô de São Paulo (2012). Esses números endossam a necessidade de melhoria do trânsito de São Paulo, com políticas planejadas voltadas para os diferentes setores que compõem o tráfego diariamente.

A busca por uma cidade sustentável e com mais qualidade de vida passa pela necessidade de tornar a distribuição de mercadorias mais eficiente (LIMA JR., 2013). A eficiência na distribuição de mercadorias pode ser atingida através de várias ações, estas devem vir do poder privado e do poder público. Diziain (2012) especifica os aspectos principais, que 
devem ser estimulados pelo poder público: inovação em tecnologia, inovação em organização da política de fretes, planejamento espacial e sistemas de tomada de decisão.

Com o objetivo de reduzir o trânsito e melhorar a fluidez do tráfego, o poder público já proferiu várias regulamentações, e é necessário considerar o bônus e a ônus de cada regulamentação, pois muitas vezes os efeitos colaterais podem suprimir os efeitos desejáveis de tal ação (BERENDS; LINDHOLM; WOXENIUS, 2008). Cunha e Yoshizaki (2014) corroboram com as contradições das restrições aos transportes de carga, ao abordarem o caso de São Paulo. Para esses autores,

Com as constantes dificuldades de deslocamento nos cenários urbanos, algumas administrações adotaram medidas de restrição ao tráfego de veículos de carga. O que, em princípio, parece ser uma solução, tem desdobramentos nem sempre benéficos para a população e para o dinamismo econômico do país. A relação do transporte de carga com a circulação e ao atendimento das necessidades das pessoas precisa ser analisada num contexto maior.

A visão de planejamento dentro de um contexto maior deve levar em consideração não só o transporte de pessoas, como tem sido a prioridade dos governantes, mas também o transporte de carga e levar em conta todos os stakeholders (fornecedores, operadores de carga, varejistas e consumidores, governo) (BALLANTYNE; LINDHOLM; WHITEING 2013).

Para exemplificar as contradições oriundas de políticas para o transporte de carga, a proibição da circulação de grandes caminhões (Três quartos, Toco, Truck e Carreta) na Zona Máxima de Restrição de Circulação (ZMRC), deve ser avaliada com cautela. A ZMRC (Figura 1) possui mais de $100 \mathrm{~km}^{2}$, e é a região com maior dinamismo econômico do município. 


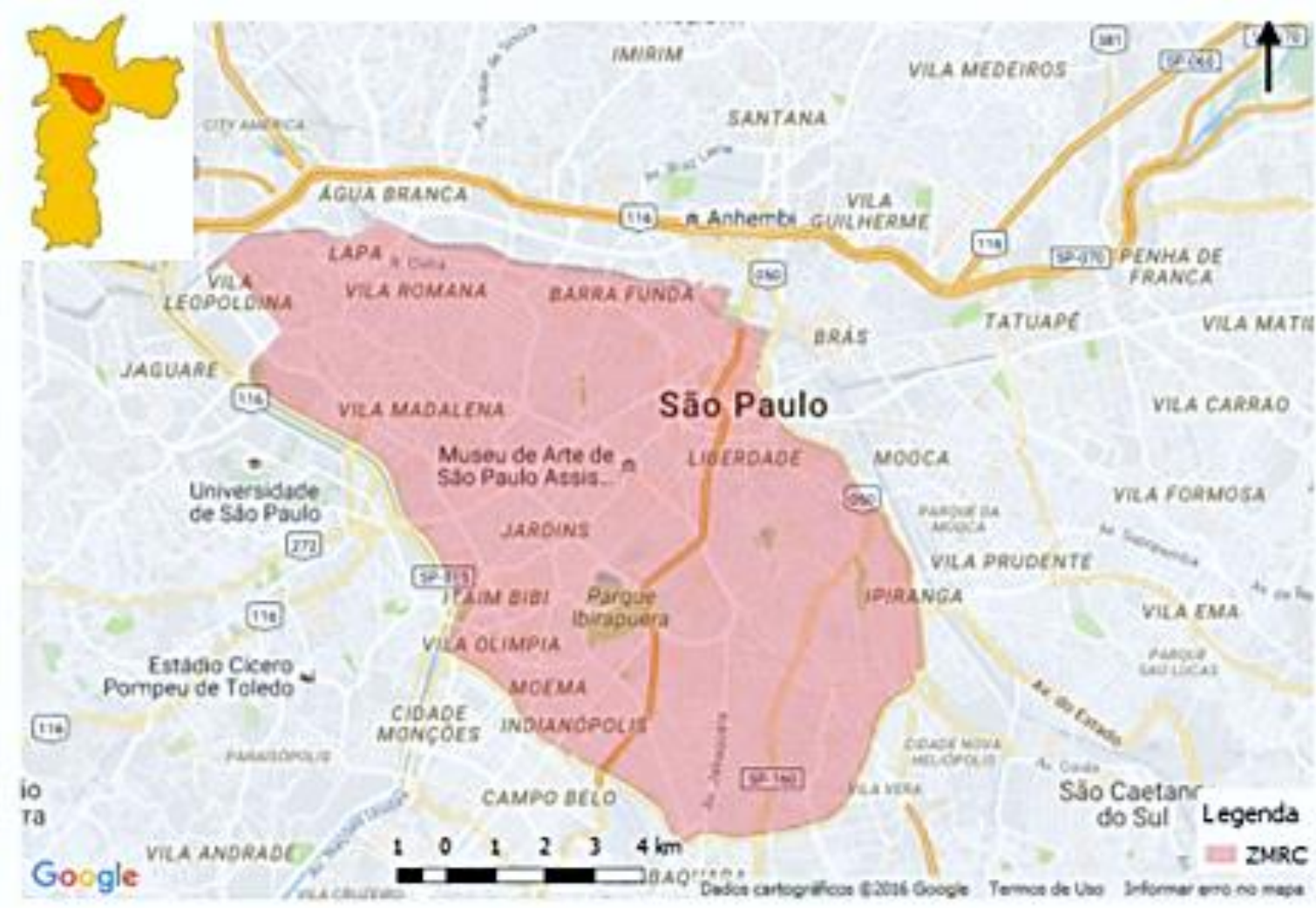

Figura 1 - Mapa da ZMRC

Nesta região só podem circular os veículos chamados de VUC (Veículos Urbanos de Carga), cuja definição é dada pelo comprimento total do caminhão, que não deve ultrapassar 7,30 metros. A capacidade desses veículos gira em torno de 3,5 toneladas, enquanto um caminhão toco pode carregar até 6 toneladas, e um caminhão truck possui uma capacidade média de 12 toneladas. Ou seja, o que poderia ser carregado em apenas um caminhão é feito em dois ou mais VUCs. O aspecto positivo desta regulamentação é que o tamanho reduzido do VUC atrapalha menos o trânsito no momento de fazer o descarregamento, por ocupar menos espaço e por ter mais facilidade para estacionar (ZAMBUZI, 2015). Holguín-Verás et al. (2014) cita os efeitos negativos desta medida no município de São Paulo, onde uma grande companhia relatou o impacto negativo da utilização dos VUCs para entregas, pois é necessário três VUCs para transportar a mesma quantidade de um caminhão truck, ou seja, aumenta a frequência de entrega.

As peculiaridades de cada região devem ser identificadas antes de planejar o sistema de transportes, pois Ambrosini e Routhuier (2004) fazem a distinção entre os diferentes tipos de estrutura urbana e os problemas enfrentados na execução de entregas no meio 
urbano, ou seja, cada localidade enfrenta problemas particulares dependendo de suas características sociais e espaciais. Os tipos de construção, as leis que regulamentam a situação da frota veicular de cada local, o tamanho dos estabelecimentos, a lei de uso do solo, são aspectos considerados relevantes por Andersson (2012) que afetam o sistema de distribuição urbana de cargas das empresas. Este mesmo autor ainda escreve que as cidades carecem de Sistemas Inteligentes de Transportes, sendo necessária a modernização desses aspectos por parte das empresas. As funcionalidades de um Sistema Inteligente de Transportes envolvem, basicamente, padrões de qualidade de atendimento e recursos de infraestrutura (MARTE et al., 2014).

As entregas noturnas constituem outra interessante alternativa que vem ganhando destaque na literatura e tem sido uma estratégia adotada crescentemente pelos governos locais de grandes cidades, como uma política voltada para os sistemas de transporte (DIZAIN, 2012). Os lugares pioneiros a realizar entregas noturnas estão nos chamados países do Norte ou desenvolvidos, basicamente na Europa Ocidental e na América do Norte (HOLGUÍN-VERAS et al., 2014). Esses locais são reconhecidos por um melhor padrão de qualidade de vida e geralmente são mais seguros do que os países do Sul, os subdesenvolvidos (COSTA, 2015).

Os países desenvolvidos também estão avançados em outro âmbito: no desenvolvimento de veículos mais sustentáveis e mais silenciosos. O PIEK Programme teve sua origem em 1998, quando o governo da Alemanha resolveu estabelecer padrões de emissão de ruído para operações de carga e descarga de mercadorias. Este programa foi o pioneiro no auxílio para o desenvolvimento de tecnologias silenciosas em veículos de carga, e uma das principais intenções do programa é contribuir para a diminuição de ruídos das entregas noturnas, além de mitigar a poluição atmosférica. (BARCELONA MUNICIPALITY, 2006).

\subsection{Objeto de estudo}

O objeto de estudo dessa dissertação é o sistema de distribuição urbana de carga no período noturno. Para tanto, uma amostra significativa de empresas que atuam no município de São Paulo é investigada. Essas empresas podem possuir mecanismos diferentes de funcionamento da cadeia de suprimentos do setor varejista. Para compreender de forma mais completa esses mecanismos, serão selecionados os seguintes sujeitos da cadeia de suprimentos para análise: 
- Motoristas: os responsáveis por conduzir os veículos.

- Recebedores: os encarregados por receber as mercadorias. Estes podem ser o gerente das lojas, o chefe de operações, o estoquista, ou um auxiliar administrativo.

\subsection{Definição do problema}

As entregas urbanas de carga impactam diretamente na intensidade do tráfego de grandes centros urbanos e na qualidade do ar desses locais, uma vez que aproximadamente $20 \%$ do espaço viário é ocupado por veículos de carga e $60 \%$ das emissões de poluentes provém destes veículos (CET, 2014).

O transporte urbano de carga é extremamente importante para garantir as atividades vitais no meio urbano, no entanto suas consequências podem ser perturbadoras para sociedade (CRAINIC; RICCIARDI; STORCHI, 2014). Entre as externalidades oriundas da distribuição derba carga no período noturno, pode-se citar problemas como o aumento do congestionamento de veículos (TANIGUCHI et al., 2011), emissão de ruídos (DOUGLAS; LAGRANGE; MABELIS, 2008) e poluição atmosférica (HOGAN el al., 2000).

Com vistas a mitigar esses efeitos colaterais do transporte de carga, diretrizes têm sido elaboradas, tanto pelo poder público quanto pelo poder privado, em diversas metrópoles do mundo. Por exemplo, restrição ao tamanho do caminhão (CUNHA; YOSHIZAKI 2014), construção de centros de consolidação de mercadorias (QUAK, 2012), utilização de veículos não-motorizados para executar o last mile (HENDY, 2012), e entregar mercadorias no período noturno (WITTLOV, 2012).

O fato de realizar as atividades de logística no período noturno traz algumas questões relevantes, que devem ser consideradas para maximizar a eficiência das entregas e também para evitar externalidades (problemas relacionados às entregas noturnas). Entre essas questões, as seguintes podem ser destacadas: emissão de ruídos (YANNIS; GOLIAS; ANTONIOU, 2006); segurança dos trabalhadores, da carga e do estabelecimento (NOEL et al., 1980); funcionários responsáveis pelo recebimento (HOLGUÍN-VERAS et al. 2014).

Além disso, alguns aspectos relevantes devem ser considerados para comparar as entregas feitas no período noturno e as entregas feitas no período diurno, entre estes pode-se realçar os seguintes: tempo de rota (QUIROGA, 2000), quantidade de multas (STATHOPOULOS; VALERI; MARCUCCI, 2011), dificuldade para estacionar o veículo e 
descarregar (ZAMBUZI, 2015), organização geral da loja e qualidade de atendimento ao cliente (HOLGUÍN-VERAS et al., 2010), pontualidade dos caminhões (MERCADONA, 2010).

As características de cada sujeito e de cada empresa vão fazer a diferença na ocasião de implementar as entregas noturnas. Além disso, a realização de entrevistas, um dos instrumentos escolhidos para esta pesquisa, pode contribuir para captar as percepções dos sujeitos em relação às entregas noturnas. Ballantyne et al. (2013) relatam a carência de conhecimento sobre como avaliar essas percepções. Por isso, uma das metas deste trabalho é avaliar das facilidades e dificuldades para realizar entregas noturnas de acordo as percepções dos sujeitos.

Assim, com base nos problemas apresentados nesta seção, pretende-se investigar e diferenciar as entregas noturnas e as entregas diurnas. Vale ressaltar que os conflitos de interesses entre os diversos stakeholders envolvidos denotam um problema de difícil resolução e, para tanto, esta pesquisa visa a esclarecer quais são esses interesses e e propor uma base de comparação entre entregas noturnas em São Paulo e em outras grandes cidades espalhadas ao redor do mundo.

\subsection{Objetivo}

O objetivo desta pesquisa é analisar a distribuição de carga no período noturno no município de São Paulo, com base na revisão bibliográfica sobre entregas noturnas em outras metrópoles do mundo e em uma survey feita com transportadores e varejistas. A survey tem como ponto de partida os trabalhos de campo feitos com os representantes desses tipos de empresas (recebedores e motoristas) durante o projeto piloto de entregas noturnas em São Paulo, no período compreendido entre outubro de 2014 e março de 2015, quando foi feito o acompanhamento de diversas rotas das empresas participantes. Especificamente, pretende-se identificar os aspectos que diferenciam a distribuição de carga urbana no período diurno e no período noturno, especificamente dos sujeitos que compõe o último elo da cadeia de suprimentos, o last mile. As perguntas de pesquisa para responder a este objetivo são:

- As entregas noturnas são mais eficientes do que as entregas diurnas a nível operacional? 
- Quais são os principais problemas relacionados às atividades de entregas urbanas de carga no período noturno?

Para a primeira pergunta os seguintes aspectos serão investigados: tempo de rota, tempo para achar uma vaga para estacionar, tipo de multa, nível de estresse (motoristas); horário de maior movimentação de clientes na loja, melhor horário para alocar mercadorias na gôndola, fila de caminhões, pontualidade dos caminhões, agilidade para conferir e estocar mercadorias, nível de estresse (estoquista). Holguín-Veras et al. (2010) também utilizou os seguintes aspectos de investigação: tempo de rota, tempo para estacionar e qualidade de atendimento ao cliente.

Para a segunda pergunta, os seguintes aspectos serão utilizados: falta de segurança no recebimento de mercadorias no período noturno, emissão de ruídos no recebimento de entregas noturnas, iluminação pública no entorno das lojas. Além disso, por meio de entrevistas com os motoristas e recebedores, a pesquisa investiga aspectos qualitativos que influenciam negativamente nas operações de entregas noturnas. Trabalhos como os de Douglas et al. (2008) e Noel et al. (1980) também abordaram esses aspectos.

\subsection{Justificativa e motivação}

O viés sustentável e eficiente das entregas noturnas entusiasma diversos políticos, empresários e pesquisadores. $\mathrm{O}$ fato de que os caminhões permanecendo menos tempo no trânsito emitem menos poluentes e, que ao fazer os serviços à noite, o veículo permanece menos tempo em trânsito, justifica a sustentabilidade das entregas noturnas. Para gastar menos combustível, e aumentar a pontualidade e a confiabilidade das entregas, pode ser vantajoso realizar o abastecimento de estabelecimentos varejistas em horários alternativos.

A política de entregas urbanas de carga das empresas impacta diretamente suas receitas, pois, segundo dados de Ballou (2006), o custo de transporte pode ser considerado a maior parte dos custos logísticos. Também chamado na literatura como "problema do caixeiro viajante", as entregas urbanas, que são feitas "porta a porta", necessitam de soluções para maximizar sua eficiência, sendo que a busca por um roteiro ideal, que seja eficaz e respeite as janelas de restrição dos recebedores é uma tarefa que tem suas complicações. 
O município de São Paulo é um dos primeiros, em países subdesenvolvidos, a testar o procedimento de entregas noturnas como uma política de transportes. O meio urbano de um país subdesenvolvido é conhecido pela falta de planejamento urbano, crescimento desordenado e elevados índices de violência (FERREIRA, 2000). A avaliação do projeto de entregas noturnas do município de São Paulo pôde evidenciar esses problemas, e no decorrer desta dissertação, as semelhanças e diferenças entre o caso de São Paulo e outros casos do mundo, serão também esclarecidas.

Recentemente, as empresas passaram a ter mais influência no direcionamento de políticas voltadas para o transporte de cargas (LINDHOLM; BROWNE, 2013). Esses autores destacam a importância da sinergia criada entre os agentes do poder público e do poder privado para os bons resultados de políticas para o transporte de mercadorias.

As políticas de transporte de cargas são motivadas por interesses relativos a certas condições locais. Por exemplo, em Londres foram os jogos olímpicos um dos indutores do abastecimento noturno de estabelecimentos comerciais implementados pelo TfL (Transport for London) (BROWNE, 2013). Na Califórnia, a motivação foi a diminuição da fila de caminhões dos Portos de Los Angeles e São Pedro (PIER PASS, 2015).

Compreender as interações entre os sujeitos ajuda a estabelecer melhores formas de organização entre os mesmos, com a meta de balancear os respectivos interesses e maximizar os benefícios das regulamentações para o transporte de cargas (ANDERSSON, 2012). Neste sentido, esta pesquisa procura descrever e analisar as entregas noturnas em São Paulo, através do ponto de vista dos sujeitos envolvidos no last mile entregas de carga noturna bem como as respectivas motivações para a execução dessas entregas.

Os programas de entregas noturnas ao redor do mundo podem servir de exemplo de como organizá-las, de que forma mitigar seus efeitos negativos, e servir de motivação para as empresas aderirem a esta proposta. A análise dos projetos, já desenvolvidos, poderá identificar ações positivas para o sucesso do programa de entregas noturnas, e relacioná-los com os conflitos de interesses e as indagações dos stakeholders de São Paulo.

É fato que são poucas as pesquisas realizadas sobre entregas noturnas na cidade de São Paulo. Em uma das poucas publicações o gerente de operações de peças e acessórios da Ford demonstra otimismo com as operações logísticas noturnas, ao destacar que "com essa nova logística de entregas noturnas, as peças já amanhecem nas oficinas dos distribuidores, aumentando a agilidade dos serviços de reparos dos veículos e a satisfação dos clientes". No 
entanto, a maioria das pesquisas existentes sobre transporte de carga na Região Metropolitana de São Paulo não analisaram entregas noturnas (VIEIRA; CARVALHO; FRANSOO, 2015; VIEIRA; FRANSOO, 2015; ZAMBUZI, 2015).

A discussão dos aspectos positivos e negativos das entregas noturnas é bastante atual, e esta dissertação, ao pesquisar sobre o caso de São Paulo, contribui para ponderar as os pontos favoráveis e os desfavoráveis da realização dos descarregamentos noturnos.

$\mathrm{Na}$ maioria dos programas e planos desenvolvidos pelo mundo, as entregas noturnas obtiveram sucesso, pois tiveram aderência de diversas empresas. Em Nova York, por exemplo, mais de 400 lojas mudaram o horário de entregas para o período noturno (HOLGUÍN-VERAS et al., 2014). Em Paris, apenas uma loja que participou do projeto piloto não aderiu às entregas noturnas (DIZAIN, 2012). Não obstante, Bhagat; Saphores e Jayakrishnan (2014) contradizem os benefícios das entregas noturnas na cidade da Califórnia.

\subsection{Escopo da dissertação}

A dissertação tem foco no transporte de carga noturna na cidade de São Paulo. O transporte público não faz parte desta dissertação. As entregas noturnas envolvem uma série de stakeholders, tais como executivos das redes varejistas das lojas recebedoras; funcionários que executam suas tarefas no interior dos Centros de Distribuição; residentes vizinhos aos estabelecimentos que fazem entregas noturnas; os clientes dos estabelecimentos aderentes às entregas no período noturno; o poder público, representado pela prefeitura, CET (Companhia de Engenharia de Tráfego) e DSV (Departamento Superior Viário); e a polícia militar. Entretanto, apenas dois stakeholders fazem parte da pesquisa empírica, os motoristas e os funcionários das lojas (recebedores) envolvidos no descarregamento de mercadorias.

A região de estudo será delimitada pelo município de São Paulo. Assim como ocorreu em outros casos do mundo, os governos municipais foram incentivadores do projeto. Além disso, as regulamentações de trânsito possuem abrangência municipal, e isto dificulta o estudo das entregas noturnas na Região Metropolitana de São Paulo, onde cada município possui suas próprias leis de transportes. 


\subsection{Organização da dissertação}

O capítulo 1 apresentou uma contextualização do tema desta dissertação, e a forma pela qual esta pesquisa poderá contribuir com o conhecimento científico da área. O capítulo 2 consiste na apresentação da revisão da literatura, com o intuito de descrever qual o estado atual das políticas de carga no município de São Paulo; como as empresas lidam com as entregas urbanas atualmente; discutir como se desenvolveram os projetos de entregas noturnas pelo mundo; comparar entregas diurnas e entregas noturnas. $\mathrm{O}$ capítulo 3 especifica a metodologia e as técnicas empregadas na elaboração dos questionários (pesquisa empírica). O capítulo 4 tem o objetivo de apresentar o tratamento dos dados levantados através das entrevistas, com a análise preliminar dos dados através das estatísticas básicas de uma amostra dos recebedores e motoristas, e a análise de correspondência, como técnica multivariada; e, finalmente, comparar os resultados da pesquisa empírica realizada no município de São Paulo, com outros programas desenvolvidos em outros locais do mundo. O capítulo 5 finaliza a dissertação com as considerações finais, enfatizando as principais contribuições dos resultados desta pesquisa, e colocando propostas para temas futuros. 


\section{Revisão Bibliográfica}

\subsection{Entregas urbanas de carga}

Historicamente, os estudos e planejamento do transporte coletivo de pessoas foram privilegiados em detrimento do transporte de cargas (DABLANC, 2007). Sendo um dos componentes do trânsito, e inter-relacionado com o transporte público e o transporte particular, o transporte de cargas passou a ter mais atenção das autoridades desde o início deste século (CHERETT et al., 2012). Sanches Júnior (2008) defende que no Brasil existe uma lacuna de 20 anos de pesquisa sobre transporte de carga, e que há pouca interação entre os governantes e as empresas quanto ao planejamento do transporte de carga em centros urbanos. No entanto, Carvalho (2014) demonstra otimismo com a mudança de atitude. Para a autora,

Felizmente, o foco das autoridades locais vem sofrendo alterações ao longo da última década, tendo em vista a relevância econômica do transporte de carga e a sua importância para o funcionamento dos centros urbanos.

O novo plano diretor estratégico do município de São Paulo, promulgado através da Lei $\mathrm{N}^{\mathrm{o}} 16.050 / 2014$, aborda aspectos sobre a o transporte de cargas que não são recorrentes em outros planos diretores das cidades brasileiras. Alguns pontos desta lei legitimam ações que devem ser aplicadas pelo poder público em relação ao transporte de cargas. No artigo 225, nota-se a importância da sustentabilidade e da qualidade de vida na elaboração de diretrizes para o sistema de transportes. Nesta lei consta que,

O Sistema de Mobilidade é definido como o conjunto organizado e coordenado dos modos de transporte, serviços, equipamentos, infraestruturas e instalações operacionais necessários à ampla mobilidade de pessoas e deslocamento de cargas pelo território municipal, visando garantir a qualidade dos serviços, a segurança e a proteção à saúde de todos os usuários, principalmente aqueles em condição de vulnerabilidade social, além de contribuir para a mitigação das mudanças climáticas. 
Nesta regulamentação, que configura uma nova política de desenvolvimento urbano, está relatado sobre o aumento da eficiência do transporte de cargas e mitigação dos impactos da circulação de veículos de frete para promover o desenvolvimento sustentável. Observa-se no texto da lei uma brecha para a implantação de entregas noturnas em São Paulo, no parágrafo VIII do artigo 227 que estabelece "melhoria das condições de circulação das cargas no Município com definição de horários e caracterização de veículos e tipos de carga".

Atualmente os governantes buscam integrar as políticas de transporte público com as políticas do transporte de carga (BALLANTYNE; LINDHOLM; WHITEING, 2013), já que há um conflito diário entre o direito de acessibilidade às lojas e o direito de acessibilidade ao transporte público, e, para reduzi-los, deve-se verificar como eles ocorrem in loco, com o intuito de identificar o comportamento dos sujeitos e fazer um dimensionamento político desses conflitos (VASCONCELLOS, 2012).

O transporte de mercadorias é mais complexo em grandes centros urbanos (DABLANC, 2007). As necessidades dos diversos stakeholders da logística urbana trazem a necessidade de buscar dispositivos que auxiliem na resolução destes conflitos de interesse (BALLANTYNE; LINDHOLM; WHITEING, 2013). O principal desafio na administração desses conflitos é concatenar os interesses nos lucros das negociações com certos limites éticos (FREEMAN, 1994). Os motivos primordiais para a existência desses conflitos em logística urbana são: falta de habilidade para traçar diretrizes de transporte por parte do poder público, falta de conhecimentos sobre aspectos essenciais para o transporte de carga, e restrições e as regulamentações para o transporte de carga (BALLANTYNE; LINDHOLM; WHITEING, 2013). Com relação a este último ponto levantado, a aceitação dessas restrições e as mudanças operacionais decorrentes dessas regulamentações podem variar de empresa para empresa (STATHOPOULOS; VALERI; MARCUCCI, 2011).

Aperfeiçoar a distribuição logística em um meio urbano é uma atividade complexa devido aos altos custos e exigência de bons níveis de serviço (TANIGUCHI et al., 2001). A intensidade na frequência de entrega em veículos leves, as questões ambientais e as entregas em locais inseguros são fatores que dificultam as operações logísticas urbanas (CRAINIC et al., 2004). Vieira, Carvalho e Fransoo (2015) destacam a influência das ruas estreita, das regulamentações, e o conhecimento limitado dos padrões de trânsito, nas operações logísticas em megacidades. As empresas podem ter maiores ou menores dificuldades em suas atividades logísticas urbanas dependendo de algumas de suas características relacionadas às condições da 
relação entre fornecedor e varejistas, frequência da necessidade dos clientes, tipo de administração da frota, entre outros (ALLEN et al. 2000).

A solução desses problemas de logística urbana pode envolver a utilização de modelos matemáticos (TANIGUCHI E AND THOMPSON 2002). Esses modelos estão baseados no conceito de City Logistics (TANIGUCHI et al. 2001):

Processo para otimização total da logística e atividades de transporte pelas companhias privadas, com suporte avançado em sistemas de comunicação em áreas urbanas considerando o ambiente do tráfego, seu congestionamento, segurança e eficiência dentro da estrutura econômica do mercado.

Taniguchi e Thompson (2002) esclarecem que os modelos matemáticos utilizados no âmbito de City Logistics abrangem a calibração de modelos de suprimentos, modelos de demanda e modelos de impacto. Os modelos de suprimentos envolvem a previsão de um nível de serviço de um sistema de transporte, fundamentados nas características da rede viária e nas previsões de demanda. Os modelos de demanda possuem o objetivo de prever a demanda do transporte de bens em rotas específicas com base nas características da indústria, da população residente, e da rede viária. Os modelos de impacto verificam as consequências ambientais, sociais, econômicas das iniciativas de City Logistics.

Por outro lado, o desempenho logístico das empresas que atuam na distribuição de carga no centro urbano é afetado negativamente pelas regras impostas pela cidade, pelas condições físicas, pela falta de colaboração entre os agentes e por outros aspectos gerais como tráfico intenso, roubos de carga, enchentes, greves (VIEIRA; CARVALHO; FRANSOO, 2015).

A próxima seção trata do nível de serviço logístico oferecido pelas empresas aos seus contratantes, de acordo com alguns aspectos-chave de análise.

\subsubsection{Qualidade de níveis de serviço para entregas urbanas de carga}

Analisar o nível de serviço de algum prestador deve ser feito com critério, ou seja, utilizando a avaliação de fatores que reflitam as condições operacionais da empresa (BALLOU, 2006). O baixo nível de serviço afeta a rentabilidade do prestador, e fatores como o tipo de transporte escolhido, condições dos veículos, cuidado com o manuseio durante as operações de carregamento e descarregamento, condições físicas do veículo e atenção com a 
documentação são aspectos que indicam a qualidade dos serviços de transporte da empresa, e consequentemente, sua reputação (FILHO, 2006). O nível de serviço da transportadora é uma questão relevante quando se trata de logística urbana (MOURA, 2004).

Alguns aspectos de análise estão associdados a indicadores de desempenho, como pontualidade da entrega, erros de pedido, documentação incompleta, índice de avarias e tempo do ciclo do pedido. $\mathrm{O}$ gerenciamento desses indicadores permite identificar onde estão as falhas na operação logística da empresa, que podem levar à perda de produtividade de mãode-obra, queda na qualidade do nível de serviço ao cliente e ao aumento de custos (SHIRO, 2011).

$\mathrm{Na}$ área de logística, as medidas de desempenho e seus efeitos oferecem apoio para aprimorar a qualidade dos serviços de pequenas e médias transportadoras, as quais costumam enfrentar percalços relacionados à escassez de orçamento próprio para pesquisa e desenvolvimento, e à falta de poder nas negaciações (ARVIDSSON; WOXENIUS; LAMMGARD, 2013). Entretanto, Rachid e Samimi (2012) alertam para o fato de que as condições econômicas de um país, em um determinado período, podem afetar a elucidação da qualidade do nível de serviço de operadores logísticos, sendo necessário considerar o momento econômico do país para uma avaliação mais eficaz. Além disso, Liu e Zhao (2010) enumeram outros fatores que fazem a diferença para delinear o desempenho das atividades logísticas: capacidade da rede, planejamento e inovação.

A eficiência das entregas urbanas de mercadoria pode ser mensurada através do estudo de alguns indicadores de desempenho (CASTRO; KUSE, 2005) os quais são importantes para avaliar a logística urbana em megacidades (VIEIRA; CARVALHO; FRANSOO, 2015). A utilização dessas métricas de desempenho pode contribuir com a avaliação dos projetos de entregas noturnas, uma etapa considerada como essencial para verificar a efetividade destes projetos (HOLGUÍN-VERAS et al., 2014).

Verificar o desempenho de entregas urbanas é essencial, pois os custos decorrentes do congestionamento em áreas intra-urbanas são 10 vezes maiores do que esses mesmos custos em áreas inter-urbanas (SMALL; DENDER, 2007). Para avaliar de forma mais completa o sistema de transportes, em áreas urbanas, é necessário considerar não só medidas de desempenho operacionais, mas também medidas de desempenho em uma escala macro ou estratégica. Entre estas, pode-se destacar o grau de co-operação entre transportadores, fornecedores e varejistas (ARVIDSSON; WOXENIUS; LAMMGARD, 2013). 
Arvidsson et al. (2013) destacam quais são os principais aspectos a serem analisados para concretizar a avaliação da logística urbana: a eficiência do motorista, eficiência do veículo, eficiência da rota (métricas de desempenho internas à atividade da transportadora); uso de sistema inteligente de transportes, taxa de ocupação do caminhão, distância percorrida com o caminhão vazio, eficiência para estacionar, eficiência das entregas, eficiência do modal (métricas de desempenho definidas conjuntamente entre transportadores, fornecedores e varejistas); impactos dos incentivos e regulamentações de políticas de transporte, coordenação da distribuição (métricas de desempenho em conjunto com o setor público).

Para medir a eficiência do sistema de transporte de carga urbana, pode-se destacar entre os principais indicadores de desempenho: tempo de viagem, quantidade de entregas em atrasos, velocidade média das rotas (QUIROGA, 2000). Susilawati, Taylor e Somenahalli (2011) esclarecem quais são os procedimentos necessários para tornar os indicadores, relacionados a tempo de rota e velocidade média das rotas, mais confiáveis. Segundo esses autores, primeiramente, é necessário um grande número de observações periódicas por dia da semana, horário de início e duração; segundo, o cálculo de tempos de rota deve ser ajustável através da distribuição de Burr; terceiro, é necessário considerar o desvio padrão e o coeficiente de variação nas análises finais.

Para Cui et al. (2015), os indicadores de desempenho podem ser utilizados para fins que vão além da efetividade do sistema logístico das empresas, eles podem indicar também onde estão os principais problemas urbanos, econômicos e ambientais, e consequentemente, quais ações por parte do poder público podem melhorar esses indicadores, já que as condições das entregas de mercadorias afetam o nível de competitividade das cidades (SAÉZ; PERIAÑEZ, 2015).

Os indicadores de desempenho da área logística da empresa podem indicar uma melhora ou piora de desempenho logístico de uma empresa, dependendo do horário de entrega das mercadorias (HOLGUÍN-VERAS et al., 2010). Diante disso, essa dissertação visa a utilizar indicadores de desempenho vinculados à pontualidade, produtividade de mão-de-obra (através do nível de estresse dos trabalhadores), qualidade de atendimento ao cliente, tempo do ciclo do pedido, para diferenciar as entregas diurnas das entregas noturnas, levando em conta fatores externos da estrutura urbana para realizar uma abordagem mais completa dos indicadores de desempenho. 


\subsection{Entregas noturnas ao redor do mundo: soluções e problemas}

Esta seção aborda aspectos interessantes do sistema de entregas noturnas adotadas em projetos desenvolvidos em várias grandes cidades ao redor do mundo. Nesses projetos, destacam-se as motivações e justificativas de implantação; os agentes e seus respectivos papéis enquanto modificadores do ambiente de entregas de carga e ocupação do espaço urbano; os ruídos e a segurança pública que se revelam como um dos principais fatores que afetam negativamente na implantação desse sistema. Vale lembrar que a falta de segurança pode constituir outro obstáculo para a realização de entregas noturnas, como foi constatado no trabalho de Noel et al. (1980). Por fim, são elecandos os resultados positivos e um resumo comparativo dos projetos já implantados.

Com base na revisão bibliográfica, são destacados aspectos que traduzem o impacto operacional decorrente da implantação de entregas noturnas, os quais serão trabalhados na pesquisa empírica. Entre estes aspectos pode-se destacar os seguintes: tempo de rota, quantidade de multas, organização geral da loja, nível de atendimento ao cliente, nível de estresse dos trabalhadores envolvidos, pontualidade dos veículos de carga.

\subsubsection{Motivações para a implantação de entregas noturnas: uma visão histórica}

A realização de entregas noturnas é antiga na história da humanidade, já que no ano 45 a.C, em Roma, o imperador Julio Cesar ordenou que os estabelecimentos comerciais realizassem entregas apenas de noite, para evitar congestionamentos (HOLGUÍN-VERÁS et al., 2010).

Todavia, em um contexto mais contemporâneo, foi Nova York a primeira cidade do mundo a executar as entregas noturnas como uma política de planejamento urbano. O projeto denominado de "The New York City Off-Hour Delivery (OHD) program", desenvolvido pelo NYDOT (New York State Department of Transportation), é fundamentado na mudança do horário de entregas em ambientes urbanos, ou seja, em vez de serem feitas entre as 6:00 e as 19:00, passa a ser realizado entre as 19:00 e as 6:00.

As motivações para a realização de entregas noturnas podem ser diversas. Em Nova York, Holguín-Verás et al. (2014) justifica que as entregas noturnas foram implementadas para corrigir falhas no mercado varejista, cujos motivos são os que seguem: ineficiência 
nas atividades, existência de monopólio, falta de marcado, mercado incompleto, externalidades, falta de direitos de propriedade, informação insuficiente e instabilidade do mercado. Com a diminuição de erros operacionais, há possibilidade de obtenção de maiores lucros se as operações tiverem melhor qualidade. Por exemplo, se as entregas urbanas forem realizadas no período noturno há menos possibilidades do caminhão atrasar, pois não há congestionamento de veículos.

A ineficiência nas atividades ocorre quando os recursos das empresas não estão sendo utilizados da melhor forma, por exemplo, quando a empresa não utiliza a vantagem de transportar mercadorias em grandes caminhões no período noturno. Como consequência, isso pode levar: (a) a um encarecimento da operação, quando se utiliza um número demasiado de utilitários ou VUCs para realizar entregas de carga; (b) à existência de monopólio, que pode estar associada ao abuso de poder que um fornecedor de serviços é capaz de exercer em relação aos transportadores; (c) à falta de mercado, que acontece quando há a impossibilidade de fornecer um serviço, mesmo quando este é solicitado, ou quando a oferta total de serviços não atende a todos os consumidores, por exemplo quando ocorrem atrasos na entrega de mercadorias, decorrentes da falta de mão-de-obra para processar a mercadoria em um centro de distribuição; (d) à externalidades, que levam a um custo sofrido por um terceiro como resultado de uma transação econômica, por exemplo, resíduos industriais e emissão de poluentes; (d) à falta de direitos de propriedade quando os donos dos recursos em transações comerciais não estão bem definidos, e a consequência disso pode ser o uso indevido desses recursos; (e) à falta de informação atrelada ao desconhecimento das operações das empresas, ou quando uma empresa possui um conhecimento vantajoso da operação em relação à outra; (f) à instabilidade de mercado, a qual pode ser explicada pela inconstância dos preços, a queda de rendimento das operações e a perda de poder de negociação para algum dos lados (ECONOMICS ONLINE, 2012).

$\mathrm{Na}$ Califórnia, as atividades de transporte de carga noturna estão atreladas ao funcionamento do porto de Long Beach e do porto de Los Angeles. Foram instituídas em 2005 pela operadora dos portos de Los Angeles e Long Beach, a PierPass, cujos objetivos principais de sua administração são: reduzir o congestionamento e as filas de caminhões nesses portos, e melhorar a qualidade do ar e a segurança (PIERPASS, 2015). 
Em Barcelona, autoridades partiram da pressuposição de que havia dois problemas substanciais: restrições ao tamanho dos caminhões em certas áreas da cidade e dificuldade de estacionamento (NICHES, 2007).

Em Roma, a concentração de estabelecimentos comerciais em uma pequena área do centro histórico dificultava sobremaneira o estacionamento dos veículos de carga, os quais acabavam descarregando em locais proibidos para estacionar. A primeira medida tomada pelo governo italiano foi proibir caminhões com capacidade acima de 3,5 toneladas de circular no centro histórico de Roma entre às $20 \mathrm{~h}$ e às $7 \mathrm{~h}$, até viabilizar um esquema de entregas noturnas junto à iniciativa privada (STATHOPOULOS; VALERI; MARCUCCI, 2011). Em Turim, houve um processo análogo ao de Roma (GEROLIMINIS; DAGANZO, 2005).

Já em Londres e Vancouver, as motivações estiveram em torno da realização de megaeventos esportivos. Muitas vezes, uma situação atípica é uma boa oportunidade para testar novas políticas de planejamento urbano (HENDY, 2012). Em Londres, os jogos olímpicos de 2012 fizeram com que as entregas noturnas fossem implementadas de uma forma mais ampla (BROWNE, 2013). Em Vancouver, foi a Olimpíada de inverno de 2010 que levou o governo a estimular a aderência às entregas noturnas (ONTARIO, 2013). Em ambos os casos, a opção de realizar entregas noturnas teve o objetivo de: garantir o deslocamento tanto de expectadores quanto dos trabalhadores; realizar as festas de comemoração com segurança; proteger a reputação dessas cidades como destino turístico; garantir o abastecimento de instituições como igrejas, escolas e hospitais (ONTARIO, 2013; BROWNE, 2013).

\subsubsection{Stakeholders e o seu papel nas entregas noturnas}

Os stakeholders envolvidos em projetos de entregas noturnas podem ser da iniciativa privada, do poder público ou da sociedade civil. Holguín-Verás et al. (2014) alertam para necessidade de viabilizar a participação de diversos grupos empresariais, para analisar o procedimento logístico noturno de empresas que funcionam de maneira diferente. Nos diferentes projetos de entregas noturnas realizados pelo mundo, o órgão público responsável por organizar o sistema de transporte do município desempenhou um papel essencial na organização desses projetos. Foi assim com o NYDOT (New York State Department of Transportation) em Nova York (HOLGUÍN-VERÁS; HODGE, 2013), o TfL (Transport for London) em Londres (AINGE et al., 2007) e o Barcelona Municipality Road em Barcelona 
(NICHES, 2007). No caso da California, a PIERPASS, administradora dos portos de Los Angeles e Long Beach, exerceu a função de organizar o projeto (PIERPASS, 2015).

Vale ressaltar que a participação de grandes empresas em projetos pilotos pode induzir outras empresas de menor porte a fazê-lo. Por exemplo, os ganhos por parte da "rede Mercadona" foram essenciais para que outros estabelecimentos também buscassem o procedimento de efetuar entregas noturnas. Os investimentos iniciais para viabilizar as entregas noturnas foram compensados em 3 anos devido, principalmente, ao melhor tempo de ocupação das vias, pois as entregas no período noturno demoravam em média 4 vezes menos para realizar o mesmo trajeto no período noturno, além dos pedidos serem feitos com menos frequência, já que eram solicitados em lotes maiores (MERCADONA, 2010).

A indústria automobilística foi colocada como um importante stakeholder para o planejamento do projeto de entregas noturnas de Dublin, pois o Instituto de Tecnologia de Dublin enfatizou a importância da produção de veículos silenciosos. Com a expansão das entregas noturnas por várias metrópoles do mundo, há a necessidade do veículo já sair da fábrica com as adaptações imprescindíveis para efetuar as entregas noturnas de maneira silenciosa. O desafio é produzir um caminhão com todas as tecnologias silenciosas recomendáveis, a um preço acessível (NICHES, 2007).

No âmbito das empresas, o gerente das transportadoras e o gerente de logística das redes de varejo possuem uma função executiva das entregas noturnas, principalmente associada aos custos logísticos dessas entregas. Já motoristas e gerentes das lojas recebedoras, possuem um olhar voltado para questões operacionais, e podem elucidar quais são as vantagens e desvantagens em realizar as entregas noturnas na rotina de trabalho das empresas (HOLGUíNVERAS, et al. 2010).

Entretanto, podem existir conflitos de interesse entre varejistas e transportadores, pois transportadores podem ter a preferência pelo horário noturno, enquanto os varejistas podem optar pelo horário comercial, pois estes podem assumir a maior parte dos custos advindos da decisão pelas operações logísticas noturnas (VIEIRA; FRANSOO, 2015). A janela de tempo limitada para efetuar as entregas de carga leva os transportadores a serem obrigados a ingressar em áreas congestionadas durante o horário de pico e a estacionar em local proibido, elevando o custo das entregas (MUNUZURI et al., 2005).

Acordos de colaboração entre varejistas, transportadores e fornecedores quanto ao horário das entregas, frequência das entregas, e os dias da semana que serão feitas as entregas 
podem melhorar o desempenho logístico da cadeia de suprimentos (BREWER AND SPEH, 2000).

\subsubsection{Problemas para as entregas noturnas}

Yannis, Golias e Antoniou (2006) relataram que o principal problema para a execução de entregas urbanas no período noturno é a emissão de ruídos. Quando os projetos de entregas noturnas europeus foram divulgados pela imprensa, prontamente a sociedade se preocupou com a poluição sonora (HOLGUÍN-VERAS et al., 2010).

Holguín-Veras e Hodge (2013) recomendam as seguintes tecnologias para mitigar os ruídos provindos do descarregamento de mercadorias: a utilização de combustíveis elétricos ou alternativos; plataformas de elevação silenciosas; revestimentos de isolamento acústico; carrinhos silenciosos, (vide Figuras 2a, 2b, 2c e 2d, respectivamente).

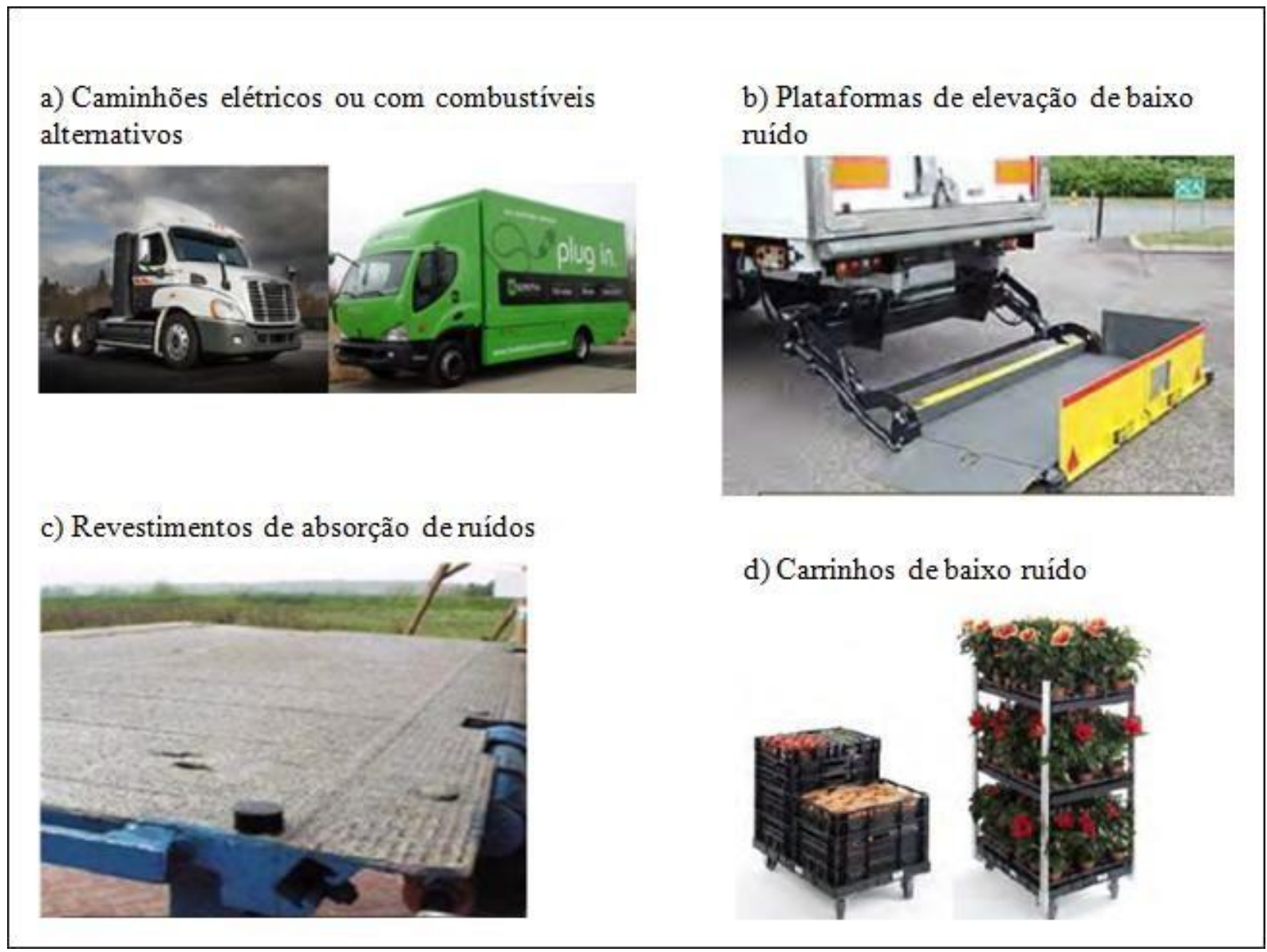

Figura 2 - Tecnologias silenciosas: combustíveis alternativos, rampas silenciosas do caminhão, revestimentos de absorção de ruídos e carrinhos silenciosos 
Apesar da sugestão de Verás e Hodge (2013) em utilizar combustíveis elétricos para mitigar os ruídos, em Barcelona, foi utilizado o gás natural, por ser considerado um combustível que emite menos poluente além de diminuir em $50 \%$ os ruídos emitidos pelo motor dos veículos (MERCADONA, 2010). Com o uso do gás natural e de outras tecnologias silenciosas, conseguiu-se, praticamente, eliminar a influência negativa das operações logísticas noturnas para a emissão de ruídos, como mostra a Tabela 1.

Tabela 1 - Ruídos emitidos em diferentes lugares de Barcelona, com e sem descarregamento.

\begin{tabular}{lll}
\hline & Locais mais silenciosos & Locais menos silenciosos \\
\hline Média do ruído do ambiente & & \\
Média do ruído do ambiente durante o descarregamento & $23,5 \mathrm{dBA}$ & $52,1 \mathrm{dBA}$ \\
& & $52,2 \mathrm{dBA}$
\end{tabular}

Fonte: Mercadona (2010)

Outros aspectos podem ser essenciais para amenizar os ruídos emitidos pelas operações logísticas notívagas, entre as quais Ainge et al. (2007) destacam: utilização da Hot Rolled Asphalt, uma tecnologia inovadora que pode ajudar a mitigar a poluição sonora; modernização da estrutura viária; treinamento com os funcionários, para que suas ações e tom de voz sejam mais silenciosos; sistema inteligente de monitoramento de velocidades; identificação de rotas cujo ruído de fundo é menos silencioso; realização de um teste de limite de ruídos.

Vale lembrar que o governo de Vancouver flexibilizou a rigidez da lei de ruídos, para que todas as operações logísticas noturnas ocorressem dentro da legalidade, de modo a evitar multas para os integrantes do projeto de entregas noturnas (ONTARIO, 2013).

Outra questão vista no projeto de Nova York, que reflete uma externalidade oriunda da entrega noturna de carga é a segurança dos trabalhadores, da carga e dos estabelecimentos, como foi assinalada por Holguín-Verás et al. (2010) ao analisar a sensação de segurança dos motoristas durante o projeto piloto de entregas noturnas de Nova York.

Não foi abordado em outros projetos de iluminação pública a respeito das condições de iluminação pública (HOLGUÍN-VERÁS, et al. 2010; DOUGLAS, 2008; STHATOPOULOS, VALERI, MARCUCCI, 2011). Entretanto, Santos (2005) enfatiza a importância da iluminação pública para a segurança e para garantir o funcionamento comercial da cidade. 
Os problemas investigados nesta dissertação se referem às externalidades como ruído, roubos e furtos, causados pela falta de segurança pública e de iluminação pública adequada.

\subsubsection{Resultados positivos}

Os resultados decorrentes da realização de entregas noturnas foram positivos nas diversas localidades. Para o caso de Nova York, Holguin-Verás et al. (2010) aponta que se 20,9\% das entregas urbanas forem executadas em horários alternativos, haverá reduções consideráveis de gases como CO (monóxido de carbono), NO (óxido nítrico), HC (gases hidrocarbonetos), e também de partículas sólidas. De forma global, foram economizados entre 150/200 milhões dólares por ano com a redução dos congestionamentos de veículos, aumento da eficiência logística e redução da poluição (HOLGUIN-VERÁS et al., 2010).

No decorrer do projeto de entregas noturnas de Nova York, foi demonstrado que se $40 \%$ dos abastecimentos noturnos das empresas fossem de maneira não assistidas, ou seja, sem um funcionário específico do recebedor para atender essa entrega, o que economiza dinheiro que seria pago a trabalhadores e suas respectivas horas extras, seria mais lucrativo e sustentável, já que gasta menos energia, e então os resultados seriam ainda melhores (HOLGUÍN-VERAS; MARQUIS; BROM, 2012).

A possibilidade de circular com caminhões maiores no período noturno melhora o desempenho logístico das entregas (HOLGUÍN-VERAS, 2002), e com a consolidação de pedidos maiores por parte das lojas houve uma redução nos gastos no valor de 9.450 euros em 5 anos na cidade de Londres (DOUGLAS, 2008).

Em Barcelona, os ganhos foram marcantes também. Desde 2001, quando o Mercadona decidiu executar os descarregamentos noturnos silenciosos, até 2010 quando já havia 407 lojas fazendo o mesmo, foram emitidas 70000 toneladas a menos de $\mathrm{CO}_{2}, 112.000$ veículos de carga foram retirados de circulação em cada ano, o que corresponde a 26 milhões de quilômetros a menos rodados (MERCADONA, 2010).

Entretanto, Bhagat, Saphores e Jayakrishnan (2014) questionam a redução da poluição atmosférica do PierPass Program e fornece evidências para este questionamento ao analisar a estimativa de emissão de poluentes, os sistemas de dispersão do ar e a avaliação do impacto na saúde da população. Todavia, não leva em consideração o efeito das filas de caminhões do porto, uma das principais motivações em modificar o horário dos fretes. Quanto à emissão 
dos poluentes, a argumentação refere-se à maior estabilidade da atmosfera no período noturno, devido à ausência da energia solar, a qual dinamiza a circulação atmosférica. Este fator é tido como agravante na dispersão da poluição atmosférica produzida no período noturno. Para o cálculo da emissão dos poluentes foi utilizado o CMEM (Comprehensive Modal Emission Model), e foi considerado o balanceamento das emissões nos períodos diurno e noturno antes do PierPass Program e depois do mesmo. Os resultados, segundo os autores, indicam que de dia as emissões de $\mathrm{NO}_{2}$ e partículas sólidas reduziram em aproximadamente $5 \%$ enquanto à noite houve um aumento de $19 \%$ de ambos, o que denota um saldo positivo na emissão total desses poluentes.

Os stakeholders relataram os ganhos provindos das entregas noturnas. Para os transportadores, houve melhora na eficiência, redução do tempo em trânsito (HOLGUÍNVERAS et al., 2014), aumento da quilometragem percorrida por caminhões maiores e mais produtivos (AINGE et al., 2007). Os fornecedores e recebedores de mercadorias tiveram maior certeza quanto a data e hora de recebimento dos produtos, o que aumentou a confiança entre ambos (HOLGUÍN-VERAS et al., 2014). Os motoristas se sentem menos estressados devido ao menor nível de congestionamento no período noturno, à maior facilidade em estacionar o veículo e ao fato de que há menos pessoas nas calçadas, o que facilita o descarregamento das mercadorias (HOLGUÍN-VERÁS et al., 2010). Os trabalhadores envolvidos na conferência dos pedidos podem se sentir menos estressados durante a noite, pois há mais comodidade para realizar essas tarefas, sem a presença de clientes no interior da loja (HOLGUÍN-VERÁS et al., 2010). Os cidadãos e ciclistas puderam desfrutar de mais qualidade de vida, pois as atividades de entrega passaram a ter menos influência em suas vidas, já que grande parte dos cidadãos não está circulando nas ruas no período da madrugada (HOLGUIN-VERÁS et al., 2014).

Iyler (2010) contribuiu com a avaliação dos resultados do impacto das entregas noturnas, ao propor uma análise do projeto de Nova York através da análise do número de viagens realizadas por caminhão no período diurno. O autor utiliza o Modelo de Demanda de Viagens Regional para estimar o número de viagens modificadas pelo horário noturno de entregas, e os dados de entrada foram estimados de acordo com o levantamento das lojas que aceitaram mudar o horário de seus abastecimentos.

A análise de sensibilidade deste modelo demonstra que, quanto maior a cobrança de taxas para os caminhões que trafegam durante o dia, melhor será o efeito no trânsito. Iyler (2010) relata uma dificuldade em estimar o impacto no trânsito através desse modelo, que se 
mostrou instável com a mudança dos dados da rede de transporte. Portanto, a avaliação dos resultados da mudança do horário de fretes no volume do tráfego é uma tarefa difícil e carece do estudo mais aprofundado de modelos matemáticos e a calibração destes.

\subsubsection{Resumo dos principais aspectos dos projetos de entregas noturnas}

De modo geral, as semelhanças entre as experiências de Nova York e Londres são: participação de uma série de empresas de diferentes setores, os ensaios foram feitos em uma pequena região delimitada em um curto período de tempo, os projetos piloto foram úteis para uma visão mais precisa do que seria uma implantação em larga escala, mas não tiveram monitoramento adequado e ocorreram falhas na coleta extensiva de dados. As principais diferenças foram: em Nova York os aspectos do mercado foram amplamente considerados; a experiência londrina foi impulsionada por uma necessidade devido à ocorrência de um evento enquanto nos Estados Unidos houve um estudo que apontou as entregas noturnas como uma boa opção para melhorar a eficiência logística; a existência de um código de prática para mitigar a poluição sonora dos descarregamentos em Londres infere que aspectos associados à mitigação de ruídos foram tidos como os mais relevantes para cidade européia.

As pesquisas relacionadas a ruídos nas cidades europeias foram bem estruturadas. Em Dublin, a responsabilidade atribuída à indústria automobilística, como um importante stakeholder para a execução de entregas noturnas silenciosas, foi um destaque. A flexibilização da lei de Ruídos de Vancouver demonstra que em alguns casos, a própria lei precisa ser modificada, aumentando o nível de decibéis permitidos, para que as empresas participantes tenham respaldo das leis para executar as descargas no período noturno.

Em Barcelona, deve-se realçar o envolvimento direto de uma empresa no planejamento das entregas noturnas, no caso, o Mercadona, elemento tido como indutor para outras empresas buscarem realizar as entregas noturnas.

De forma geral, os projetos de entregas noturnas estudados nesta dissertação tiveram semelhanças e diferenças, e as peculiaridades de cada um deles permitiram melhor delineamento da pesquisa. O Quadro 1 fornece uma síntese dos aspectos desses estudos de caso. 


\begin{tabular}{|c|c|c|c|c|}
\hline Locais & Motivações & Principais Stakeholders & Problemas & Principais aspectos \\
\hline $\begin{array}{l}\text { Nova } \\
\text { York }\end{array}$ & $\begin{array}{l}\text { Ineficiência na cadeia } \\
\text { de suprimentos. }\end{array}$ & $\begin{array}{l}\text { NYDOT, Renssealer } \\
\text { Polytechnic Institute, } \\
\text { varejistas e fabricantes. }\end{array}$ & $\begin{array}{l}\text { Ruídos e } \\
\text { segurança. }\end{array}$ & $\begin{array}{l}\text { Enfatizou as entregas } \\
\text { não-assistidas, serviu } \\
\text { de exemplo para outras } \\
\text { cidades. }\end{array}$ \\
\hline Londres & $\begin{array}{l}\text { Olimpíadas } \\
2012 .\end{array}$ & $\begin{array}{l}\text { TfL, varejistas, operadores } \\
\text { logísticos e fornecedores. }\end{array}$ & Ruídos. & $\begin{array}{l}\text { Identificação de } \text { rotas } \\
\text { noturnas, solução } \text { de } \\
\text { problemas a curto } \\
\text { prazo, código } \\
\text { práticas sileciosas. }\end{array}$ \\
\hline Califórnia & $\begin{array}{l}\text { Filas de caminhão } \\
\text { nos Portos. }\end{array}$ & PierPass e sociedade. & $\begin{array}{l}\text { Ruídos e } \\
\text { poluição. }\end{array}$ & $\begin{array}{ll}\text { Melhorou a } & \text { eficiência } \\
\text { portuária, questionou o } & \\
\text { efeitor r } & \text { ambiental } \\
\text { positivo das } & \text { entregas } \\
\text { noturnas. } & \end{array}$ \\
\hline Barcelona & $\begin{array}{l}\text { Restrição ao } \\
\text { tamanho dos } \\
\text { caminhões e } \\
\text { dificuldades de } \\
\text { estacionamento. }\end{array}$ & $\begin{array}{l}\text { Barcelona Municipality Road, } \\
\text { Traffic Department SVP, } \\
\text { Supermercado Mercadona, } \\
\text { associações de varejistas e } \\
\text { fornecedores. }\end{array}$ & Ruídos. & $\begin{array}{l}\text { Estudou os ruídos de } \\
\text { fundo e a influência da } \\
\text { descarga na medição dos } \\
\text { ruídos. }\end{array}$ \\
\hline Dublin & $\begin{array}{l}\text { Resultados positivos } \\
\text { de outros projetos de } \\
\text { entregas noturnas }\end{array}$ & $\begin{array}{l}\text { Dublin Institute of } \\
\text { Technology, varejistas } \\
\text { fornecedores. }\end{array}$ & Ruídos. & $\begin{array}{l}\text { Apontou a indústria } \\
\text { automobilítica como } \\
\text { um dos responsáveis } \\
\text { por mitigar os ruídos. }\end{array}$ \\
\hline
\end{tabular}

Quadro 1 - Quadro-síntese dos aspectos dos projetos de entregas noturnas em grandes cidades 


\subsection{Comparação entre entregas diurnas e entregas noturnas}

As entregas noturnas e as entregas diurnas podem ser vistas como dois sistemas distintos, pois possuem ambientes diferentes com restrições peculiares ao horário. O estudo comparativo das duas permite conhecer melhor as vantagens e desvantagens de cada uma, no sentido de contribuir para uma tomada de decisão coerente em relação ao agendamento de caminhões que trafegam de dia ou de noite. A seguir, algumas considerações básicas do enfoque sistêmico (CHURCHMAN, 1968) são utilizadas para nortear a análise.

O sistema de entregas urbanas de carga pode ser dividido em dois sistemas menores: sistema de entregas diurnas e sistema de entregas noturnas. Os objetivos centrais do sistema de entregas diurnas são equivalentes aos do sistema de entregas noturnas. Pode-se dizer que o objetivo central é realizar todas as entregas agendadas com eficácia e eficiência, ou seja, cumprindo o que está indicado no romaneio e maximizando a eficiência.

A eficiência do sistema, para Churchman, (1968) está atrelada ao melhor modo de executar uma tarefa, sempre com vistas à redução de custos. A avaliação do desempenho das partes operacionais deve ser realçada pelo administrador no sentido de evitar falhas no sistema.

$\mathrm{O}$ ambiente do sistema e suas coações fixas se relacionam com as restrições impostas a este sistema. Nesta etapa de análise, as diferenças entre entregas diurnas e entregas noturnas ficam mais evidentes, a começar pela restrição ao tamanho do caminhão no período diurno na ZMRC. As restrições estão identificadas no Quadro 2. 


\begin{tabular}{|c|c|}
\hline \multicolumn{2}{|l|}{ Autorizados } \\
\hline \multirow{7}{*}{ Em período integral } & Veículo Urbano de Carga - VUC \\
\hline & Cobertura Jornalística (links e/ou geradores) \\
\hline & Correios \\
\hline & Serviços de Urgência (bombeiro, polícia, fiscalização/operação de trânsito e ambulâncias) \\
\hline & Serviço Emergencial de Sinalização de Trânsito \\
\hline & (*) Obras e Serviços de Emergência até $48 \mathrm{~h}$ da comunicação ao órgão de trânsito \\
\hline & Socorro Mecânico de Emergência (guincho) \\
\hline \multirow{3}{*}{ Das $05 \mathrm{~h}$ às $16 \mathrm{~h}$} & Coleta de Lixo \\
\hline & Concretagem \\
\hline & Remoção de Terra em Obras Civis \\
\hline \multirow{3}{*}{ Das $10 \mathrm{~h}$ às $16 \mathrm{~h}$} & Prestação de Serviços Públicos Essenciais \\
\hline & Remoção de Entulho e Transporte de Caçamba \\
\hline & Transporte de Produtos Perigosos de Consumo Local (com até 2 eixos traseiros) \\
\hline Das $10 \mathrm{~h}$ às $20 \mathrm{~h}$ & Transporte de valores \\
\hline \multicolumn{2}{|c|}{ Com Autorização Especial } \\
\hline \multicolumn{2}{|c|}{$\begin{array}{l}\text { Os setores cujas atividades estão abaixo relacionadas podem receber Autorização Especial para o trânsito na região } \\
\text { da ZMRC, conforme prevê a legislação específica. }\end{array}$} \\
\hline \multirow{2}{*}{ Em períodointegral } & Acesso a estacionamento próprio \\
\hline & Obras e Serviços de Emergência entre $48 \mathrm{~h}$ e 15 dias da comunicação ao órgão de trânsito \\
\hline Das $05 \mathrm{~h}$ às $12 \mathrm{~h}$ & Transporte de Produtos Alimentícios Perecíveis \\
\hline \multirow{4}{*}{ Das $05 \mathrm{~h}$ às $16 \mathrm{~h}$} & Concretagem-Bomba \\
\hline & Feiras-Livres \\
\hline & Mudanças \\
\hline & Obras e Serviços de Infraestrutura Urbana \\
\hline
\end{tabular}

Quadro 2 - Restrições a caminhões na ZMRC (Fonte: CET) 
O Quadro 2 apresenta as restrições a caminhões maiores que VUC, as quais se estendem entre as $05 \mathrm{~h}$ e $20 \mathrm{~h}$. Ou seja, quanto ao tamanho do caminhão e tipo de serviço não há restrições no período noturno. Portanto, durante a noite, é permitida a circulação de todos os tipos de caminhões, inclusive de caminhões maiores, os quais são considerados mais eficientes (HOLGUÍN-VERAS, 2002), o que consititui uma das vantagens de realizar entregas noturnas.

Além dessa norma da ZMRC, existem as chamadas Vias Estruturais Restritas (VER), onde está proibido o trânsito não só de caminhões maiores, mas também de VUCs. A Figura 3 traz um mapa com a classificação dessas vias, que se concentram no centro expandido da cidade. Algumas possuem restriço entre às 5 e 9 horas da manhã e entre às 17 e 22 horas, enquanto em outras, não podem circular nenhum tipo de caminhão ou entre às 05 e 21 horas ou entre às 04 e 22 horas. As vias que se enquadram nesta última janela de tempo foram regulamentadas pela portaria 124/12- SMT.GAB. Diante dessa situação, executar entregas noturnas pode facilitar a roteirização dos veículos de entregas, já que alguns caminhos são facilitados por não haver vias proibidas durante a noite, além de evitar que ocorram multas por circular em VERs. 


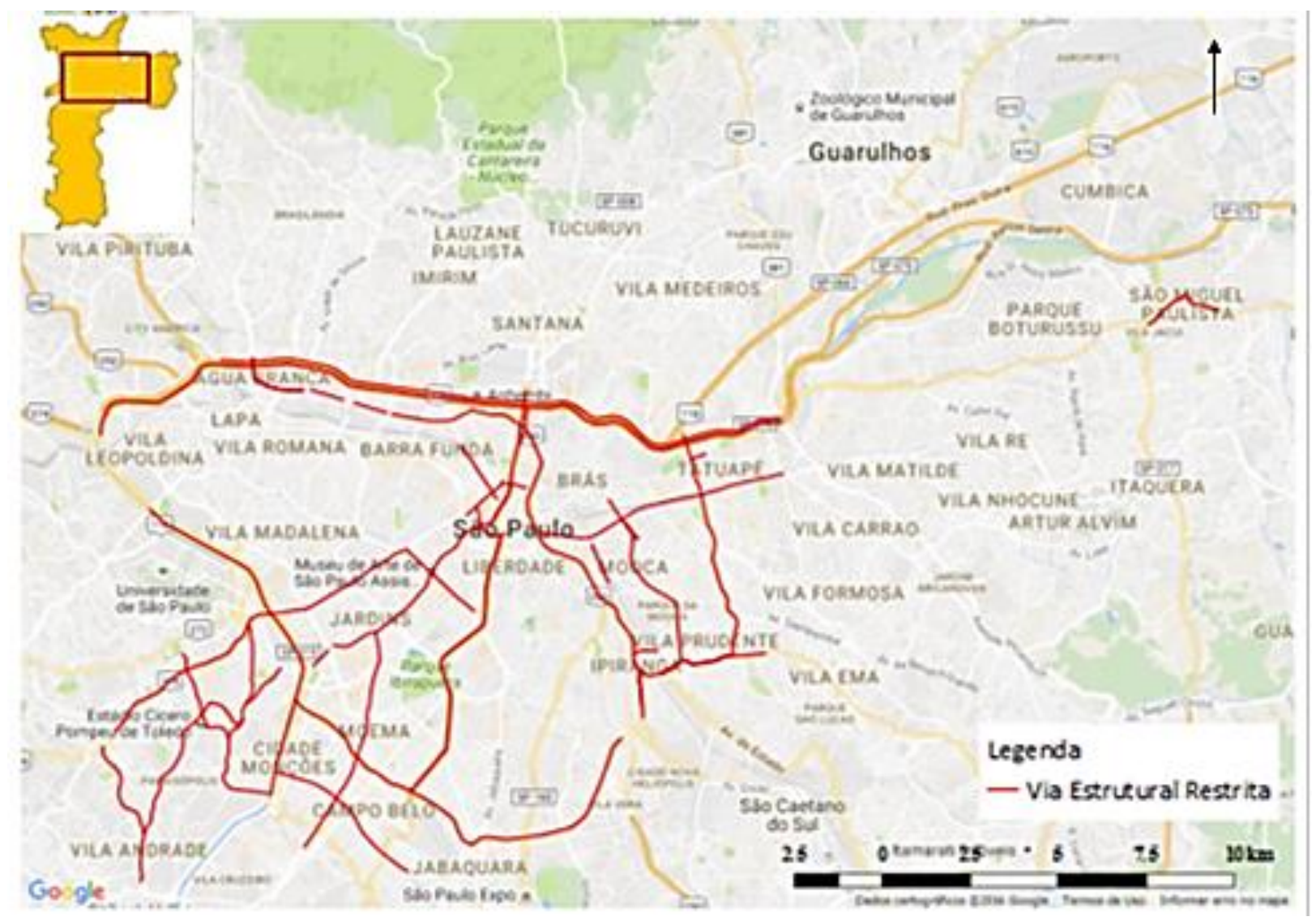

Figura 3 - Mapa das Vias Estruturais Restritas

Outra restrição que ocorre em uma área ainda maior que a ZMRC é o rodízio municipal regulamentado pelo final da placa do veículo, e proíbe os veículos (inclusive caminhões) de circular entre as 7 e as 10 e entre as 17 e as 20. Esta norma é aplicada no centro expandido de São Paulo, uma região que engloba a ZMRC e outras regiões, e é delimitada pelo mini-anel viário de São Paulo. Esta região está representada na Figura 4. 


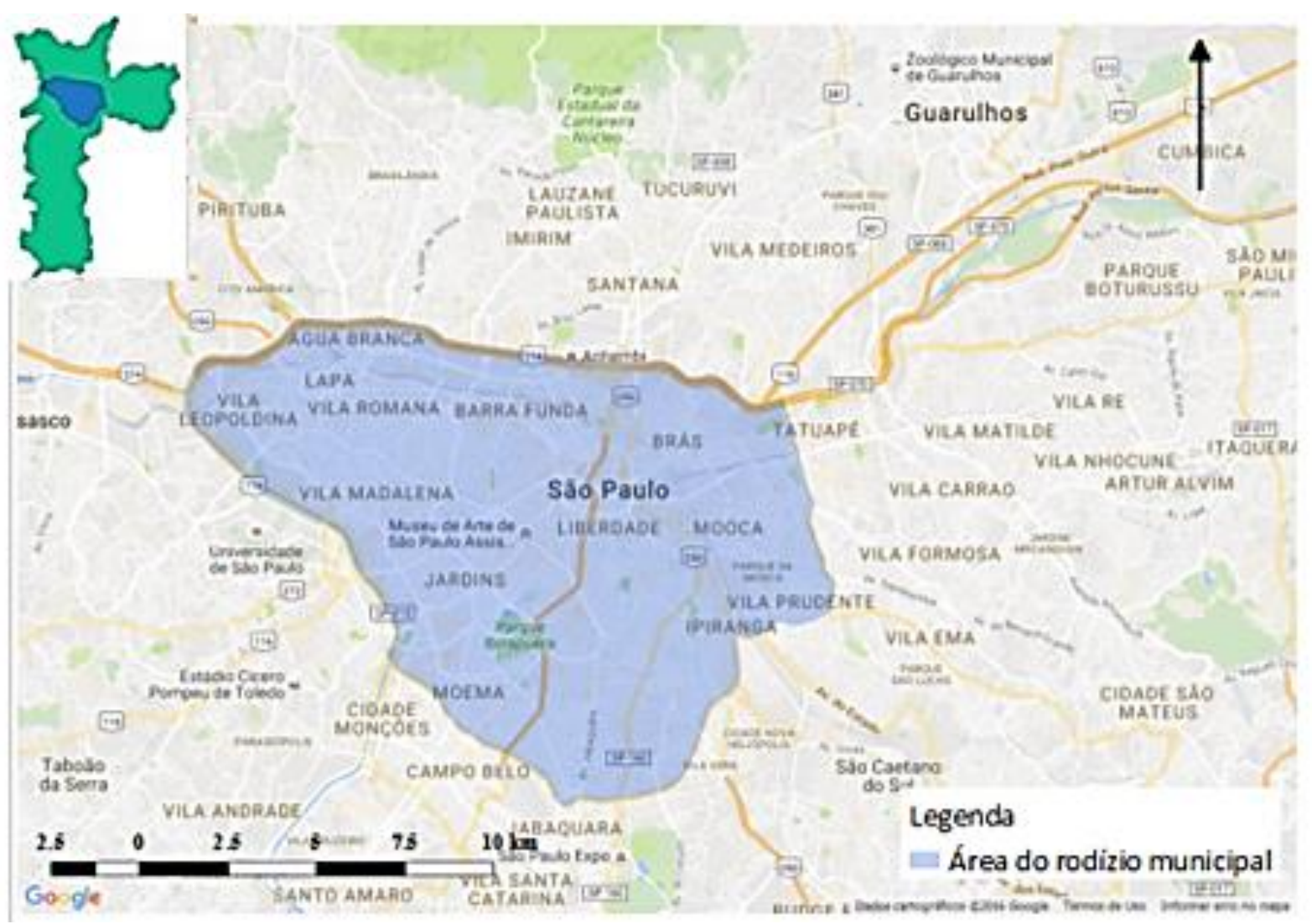

Figura 4 - Área do rodízio municipal

Essas restrições que envolvem as Vias Estruturais Restritas (VER), a ZMRC e a área de rodízio municipal, dificultam a roteirização dos veículos de carga atuantes nestas regiões de São Paulo (VIEIRA; CARVALHO; FRANSOO, 2015). Esta situação se agrava ainda mais com as janelas de tempo impostas por certos recebedores, o que pode aumentar os custos logísticos (QUERESHI; TANIGUCHI; YAMADA, 2010).

Os tipos de estabelecimentos vizinhos ao estabelecimento receptor de mercadorias fazem parte do ambiente do sistema de entregas urbanas e também oferece restrições às operações logísticas, já que a lei de uso do solo do município de São Paulo estabelece limites do volume dos ruídos emitidos de dia e de noite, de acordo com o tipo das atividades que se desenvolvem em cada zoneamento da cidade. Vale ressaltar que os ruídos emitidos pelas operações logísticas noturnas foram considerados o aspecto mais grave visto nos projetos desenvolvidos em outros países (HOLGUÍN-VERAS et al.; AINGE et al., 2014),

A divulgação do zoneamento da cidade está dividida por subprefeituras, sendo que a divulgação do mapa de zoneamento é feita no site das respectivas subprefeituras. Os limites 
de ruído definidos na lei de zoneamento do município estão definidos conforme os tópicos a seguir:

- Zona Residencial: das 7 às 19h, 50 dBA. Das 19 às 7h, 45 dBA.

- Zona Mista: das 7 às 22h, 65 dBA. Das 22 às 7h, 45 dBA.

- Zona Industrial: das 7 às 22h, 65 dBA. Das 22 às 7h, 55 dBA.

Esses limites foram calculados conforme estudos realizados pela OMS (Organização Mundial da Saúde) (BERGLUND; LINDVALL, 1995), e os danos causados à saúde humana podem ser intensos. As consequências para saúde humana, para cada valor em dBA, podem ser vistos no Quadro 3.

\begin{tabular}{|l|l|l|}
\hline $\begin{array}{l}\text { Intensidade sonora } \\
\text { (dB) }\end{array}$ & Reação & Efeitos negativos \\
\hline Até 50 & Confortável (limite OMS). & Nenhum. \\
\hline Acima de 50 & O ORGANISMO HUMANO COMEÇA A SOFRER IMPACTOS DO RUÍDO. \\
\hline 55 a 65 & $\begin{array}{l}\text { A pessoa fica em estado de } \\
\text { alerta, não relaxa. }\end{array}$ & $\begin{array}{l}\text { Diminui o poder de concentração e prejudica a } \\
\text { produtividade no trabalho intelectual. }\end{array}$ \\
\hline 65 a 70 & $\begin{array}{l}\text { Organismo reage para } \\
\text { tentar adaptar-se ao } \\
\text { ambiente. }\end{array}$ & $\begin{array}{l}\text { Diminui a resistência imunológica do organismo e } \\
\text { aumenta a concentração de colesterol no sangue. }\end{array}$ \\
\hline Acima de 70 & $\begin{array}{l}\text { O organismo fica sujeito a } \\
\text { estresse degenerativo e pode } \\
\text { abalar a saúde mental. }\end{array}$ & $\begin{array}{l}\text { O corpo libera hormônios e susbtâncias que provocam } \\
\text { doenças como hipertensão, paradas cardíacas e alto nível } \\
\text { de estresse. }\end{array}$ \\
\hline
\end{tabular}

Quadro 3 - Efeitos de ruídos no corpo humano (Fonte: Silêncio Negado)

Além das empresas serem obrigadas a cumprir o limite de ruído por lei, o embate com os vizinhos do local pode trazer prejuízos às vendas do estabelecimento e desgastar a imagem 
da empresa perante a sociedade, e ocasionalmente, há a possibilidade de ser identificada como aquelas que não cumprem sua responsabilidade social.

Outra característica importante, que diferencia o ambiente das entregas diurnas do ambiente das entregas noturnas, é o fluxo de veículos nas vias da cidade. A capacidade viária pode ser melhor aproveitada se reduzir a ociosidade das vias durante a madrugada. A Figura 5 representa o fluxo de veículos no mini-anel viário de São Paulo, e demonstra a discrepância da fluidez de veículos para cada hora do dia.

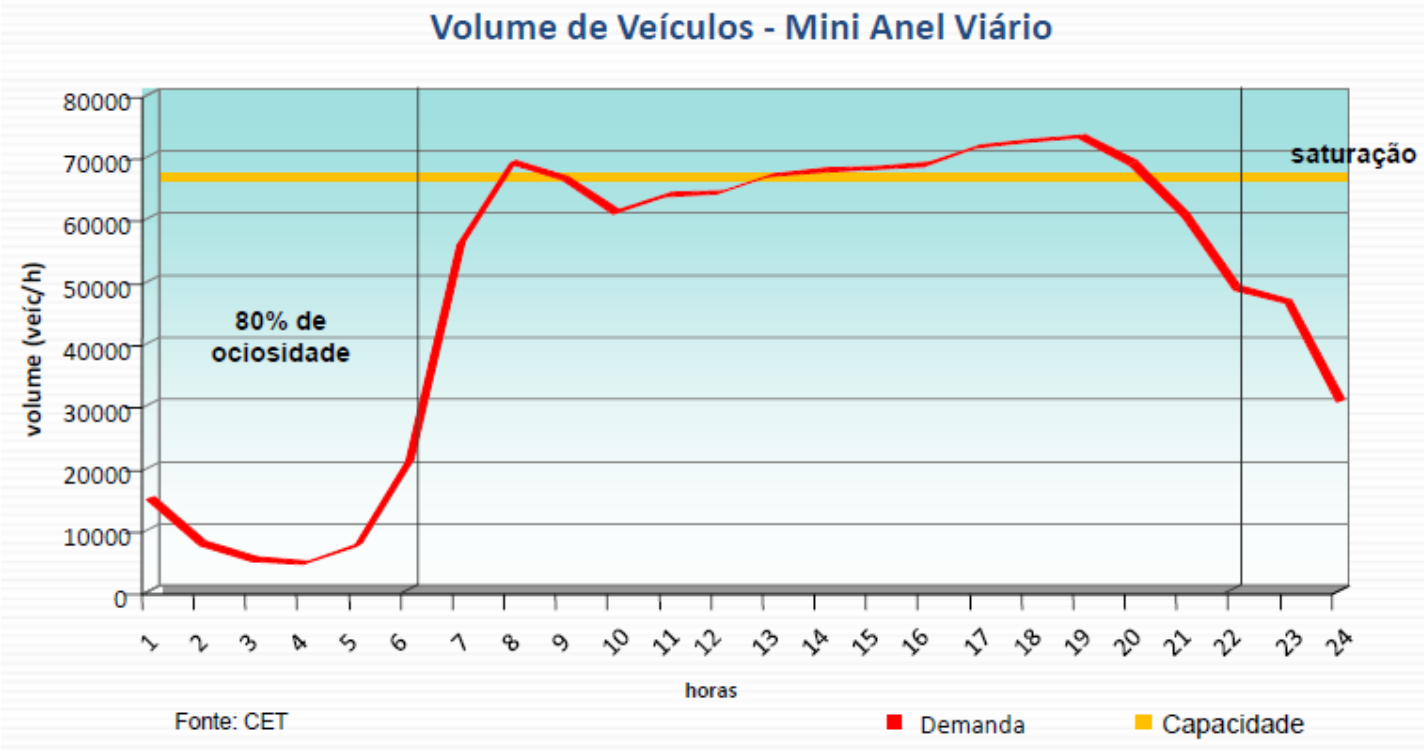

Figura 5 - Fluxo de veículos no mini-anel viário

Se a empresa escolher a noite para abastecer suas lojas, pode haver um melhor aproveitamento no roteiro de entregas, já que o veículo passará menos tempo em trânsito, pois o fluxo de veículos é bem menor (HOLGUÍN-VERÁS et al., 2014). Existem horas do dia (entre às $8 \mathrm{~h}$ e $20 \mathrm{~h}$ ) em que as vias se encontram em estado de saturação, fato que pode levar o veículo a permanecer horas no congestionamento, trazendo efeitos negativos no circuito econômico, na qualidade de vida das pessoas e no meio ambiente. Já entre às $22 \mathrm{~h}$ e $7 \mathrm{~h}$, o fluxo de veículos no interior da ZMRC é inferior a 50000 por hora, o que denota mais rapidez nas entregas de mercadorias, menos poluentes emitidos e menos quilômetros de trânsito rodados, se os veículos de carga circularem nessa faixa de horário.

Outro aspecto do ambiente das entregas de carga que deve ser abordado nesta análise é o roubo de cargas no país. Ribeiro (2009) diferencia as características de roubos em rodovias 
daquelas de roubos em áreas urbanas, e uma das principais diferenças é o horário em que ocorrem os delitos. Este autor, ao levantar esses dados concluir que:

Diferentemente dos dados que envolvem áreas urbanas, como descrevemos anteriormente, nas rodovias os roubos se aferem, principalmente, em horários noturnos, enquanto o caminhão está se locomovendo ao seu destino de entrega [...].

Enquanto os roubos de carga em áreas urbanas se concentram entre as 6 e às 16h, com pico entre 10 e às $12 \mathrm{~h}$, os roubos em rodovias ocorrem preferencialmente entre as $20 \mathrm{e}$ às $00 \mathrm{~h}$ (RIBEIRO, 2009). A escolha por abordar os roubos de carga no ambiente do sistema de entregas urbanas teve o intuito de refutar a hipótese de que o período noturno é mais susceptível a assaltos, principalmente no que se refere à segurança das cargas e dos sujeitos envolvidos nas operações de carga e descarga.

As diretrizes atuais de segurança pública se colocam no sentido de, em um primeiro momento, evitar que ocorra a ação. Além disso, deve-se levar em consideração a opinião da sociedade sobre quais ações podem contribuir para melhorar a segurança pública em geral (SOUSA, 2007).

Os recursos do sistema de entregas urbanas provêm das finanças das empresas participantes e dos investimentos do governo. Destaca-se que, em outras cidades como Nova York, Califórnia e Paris, houveram incentivos financeiros para as empresas que executassem as entregas noturnas, através de isenções fiscais (HOLGUÍN-VERAS et al., 2013), premiação com tickets de estacionamento ou com o direito de circular em dias de rodízio (PIER PASS, 2015), e até com fornecimento de quantias financeiras diretas (DIZAIN, 2012).

O aumento inicial com os gastos em razão de fatores como implantação de $3^{\circ}$ turno, instalação de câmeras e alarmes, adicional noturno, horas extras e até um custo de oportunidade, que ocorre quando a empresa renuncia a um procedimento, neste caso, às entregas diurnas, geram um gasto para a empresa, que pode ser compensado com o aumento da eficiência, marketing de sustentabilidade, redução de multas. Essa compensação de custos foi mais precisamente apresentada por Holguín-Verás et al. (2014) para o caso de Nova York. Os recursos do sistema são necessários para garantir a segurança patrimonial e das pessoas envolvidas, para melhorar a infraestrutura de recebimento, melhorar a iluminação de vias 
públicas, criar condições para garantir o deslocamento dos trabalhadores do $3^{\circ}$ turno, entre outros.

Os componentes do sistema de entregas diurnas são semelhantes aos componentes do sistema de entregas noturnas: o centro de distribuição e os colaboradores responsáveis por despachar as mercadorias; o motorista e o veículo de deslocamento; o rastreador do veículo e o interlocutor da empresa de rastreamento para fazer contato com o motorista; as lojas que comercializam os produtos e os funcionários para realizar o recebimento (no caso de entregas não assistidas, não há funcionários); os veículos e as pessoas que fazem a escolta do caminhão; a polícia militar, que é responsável por evitar os roubos de carga.

As medidas de desempenho de um sistema de distribuição de carga também podem utilizar KPIs (Key Performance Indicators). Alguns KPI mais usados para o ramo de logística são: porcentagem de vendas atendidas, proporção de produtos sem avaria, quantidade de horas ou dias entre a colocação do pedido e a entrega da mercadoria, consumo de combustível por rota, porcentagem de operações ocorridas dentro de agendamento prévio, entre outros (GIACON, 2015). Esses indicadores também podem ser utilizados para mensurar os ganhos ou as perdas no que se refere à realização das entregas noturnas.

Diante das fraquezas dos sistemas de entregas urbanas, tanto diurno quanto noturno, alternativas devem ser geradas para corrigir eventuais falhas. Por exemplo, em caso de falta de segurança nas rotas urbanas, há duas alternativas: colocar escolta particular (CAIXETA FILHO; GAMIERO, 2002) ou promover uma atuação em conjunto entre as empresas, inclusive seguradoras, e a Polícia Militar, Polícia Civil e Polícia Federal (MOREIRA; CARVALHO, 2011). Em caso de problemas com ruído, pode-se ter alternativas de tecnologias silenciosas, de reforma da estrutura de recebimento (DOUGLAS et al., 2008) ou de efetuar as entregas no período diurno.

O monitoramento contínuo das atividades do projeto favorece a análise sistêmica, devido à possibilidade de identificar as fraquezas do sistema e assim gerar alternativas, avaliá-las e colocar o sistema em constante melhoramento (NEUFVILLE; STAFFORD, 1971). 


\section{Metodologia}

A metodologia de pesquisa tem base num levantamento de dados junto às empresas do setor varejista que participam de entregas noturnas. Primeiramente, foi feita uma análise de dados a partir da pesquisa empírica, e após foi elaborada uma comparação dos resultados das entregas noturnas na cidade de São Paulo à luz dos projetos já desenvolvidos em outras cidades. A revisão de literatura serviu de base para elaborar um questionário estruturado a ser aplicado aos motoristas (responsáveis pelas entregas efetivamente) e aos recebedores (responsáveis pelo recebimento das mercadorias) com o objetivo de obter qual a percepção dos representantes dos transportadores/embarcadores e varejistas com relação às entregas noturnas na cidade de São Paulo (segunda parte do objetivo geral desta dissertação). Esses agentes possuem o interesse em fazer entregas noturnas no município de São Paulo. O questionário foi aplicado durante um plano piloto entre os dias 13/10/2014 a 25/03/2015. Com base nesse piloto e na revisão, o questionário foi aplicado às demais representantes das empresas (transportadoras/embarcadoras e varejistas) que participam do programa de entregas noturnas na cidade de São Paulo. Adicionalmente, foram feitas entrevistas com todos os motoristas e com todos os recebedores que participaram da pesquisa empírica.

\subsection{Perguntas de pesquisa}

O capítulo 2 abordou a revisão de literatura com base em dois aspectos: (a) entregas urbanas de carga, com foco nas diferenças em realizar entregas urbanas de carga no período noturno e no período diurno; (b) projetos de entregas noturnas realizadas em várias cidades do mundo. De acordo com a revisão bibliográfica, entregar produtos à noite, pode ser mais eficiente (HOLGUÍN-VERAS et al., 2011), pois envolve menos custos logísticos e operacionais (MERCADONA, 2010). Entretanto, alguns problemas podem advir em decorrência dos descarregamentos noturnos, relacionados aos ruídos emitidos durante o descarregamento (AINGE et al., 2007) e aos riscos atrelados à segurança pública. Vale ressaltar que este risco envolve a segurança da carga, a segurança do estabelecimento e a segurança dos trabalhadores envolvidos. (CAIXETA FILHO; GAMIERO, 2002).

O primeiro fator de análise está atrelado à eficiência do sistema logístico, no sentido de assinalar em qual período, diurno ou noturno, o objetivo de entregar mercadorias em bom 
estado de conservação e no momento certo, necessita de menos energia e recursos. Os veículos ao permanecer menos tempo em trânsito oferecem mais previsibilidade e pontualidade nos eventos do circuito logístico (LJUBICIC; PAVLOVIC, 2015), além de facilitar o descarregamento, por haver menos possibilidades da presença de clientes e outros cidadãos que atrapalham a descarga (HOLGUÍN-VERAS et al., 2014).

A qualidade de atendimento ao cliente também pode ser melhorada com a decisão de realizar entregas noturnas, como foi constatado por Holguín-Veras et al. (2011). A constatação dos aspectos de análise que fortalecem a essa afirmação faz parte do escopo desta dissertação, assim como graduar quais destes aspectos mais contribuem para a elevação do nível de atendimento ao cliente.

Além disso, a possibilidade de realizar entregas não-assistidas, sem a presença de um funcionário interno da loja, pode reduzir o consumo de energia elétrica no estabelecimento e os custos com salários adicionais aos funcionários (HOLGUÍN-VERAS et al., 2011). A comparação entre a quantidade de multas no período noturno e no período diurno também é um fato a ser investigado quanto à eficiência dos dois sistemas (STATHOPOULOS; VALERI; MARCUCCI, 2011). Diante disso, a primeira pergunta da pesquisa é:

1. Quais fatores mais influenciam na eficiência das entregas noturnas?

Esta pergunta determina quais aspectos sustentam a hipótese de que as entregas noturnas são mais eficientes do que as entregas diurnas (HOLGUÍN-VERAS et al., 2011; MERCADONA, 2010). No entanto, foi visto na revisão bibliográfica que existiram problemas com ruídos nos outros projetos de entregas noturnas pelo mundo (AINGE et al., 2014), e que podem ocorrer delitos no período noturno como roubo de carga durante o trajeto, roubo no descarregamento e risco à integridade física dos funcionários envolvidos no descarregamento. O Brasil é o país campeão mundial em roubos de carga, superando países como México, África do Sul e Síria (MUNDO LOGÍSTICA, 2015), o que endossa à necessidade da questão da segurança ser abordada como um entrave a realizar as entregas noturnas. Adicionalmente, com base na preorrogativa de que a iluminação pública é um importante fator para garantir a segurança do patrimônio e da sociedade (SANTOS, 2005), as condições de iluminação pública também podem ser colocadas como um obstáculo para que ocorra as entregas noturnas. Diante desses aspectos, pergunta-se 
2. Quais são os principais problemas para a realização das entregas noturnas?

Responder esta pergunta envolve a identificação e hierarquização dos principais entraves para a execução dos descarregamentos noturnos, de forma a ponderar quais problemas mais prejudicam a adoção das entregas noturnas por parte das empresas.

\subsection{Projeto-piloto de enteregas noturnas no município de São Paulo}

A revisão de literatura serviu como base para elaborar o instrumento desta pesquisa, um questionário estruturado a ser aplicado às empresas que fazem entregas noturnas no município de São Paulo. Inicialmente, uma pesquisa exploratória foi realizada durante um plano piloto entre os dias 13/10/2014 a 25/03/2015, com o objetivo de melhorar o entendimento das entregas noturnas. Participaram dessa pesquisa, varejistas e transportadoras.

O projeto piloto de entregas noturnas do município de São Paulo foi desenvolvido por órgãos governamentais, entidades e empresas do setor privado, e pela Universidade de São Paulo. O objetivo deste projeto piloto foi identificar e analisar as vantagens e desvantagens de realizar entregas noturnas no interior da ZMRC, onde há restrição quanto à circulação de grandes caminhões (ANTP, 2015).

O propósito de reduzir os quilômetros de congestionamento, como ocorreu em diversos projetos de entregas noturnas em outras cidades do mundo foi a principal motivação de iniciar tal projeto. Com o intuito de facilitar a avaliação do impacto do projeto na redução do excesso de veículos da estrutura viária, foi delimitada uma região em que seria realizada o projeto. A região do piloto ficou delimitada a leste pela Avenida Pacaembú, a oeste pela Avenida Pompéia, a norte pela Marginal Tietê e a sul pelas avenidas Heitor Penteado e Doutor Arnaldo, como retrata a Figura 6. Nota-se que a maior parte da região do projeto piloto se localiza no interior da ZMRC, e uma pequena parte se encontra fora desta Zona, porém dentro do centro expandido da cidade, como mostra a Figura 6 (ANTP, 2015). 


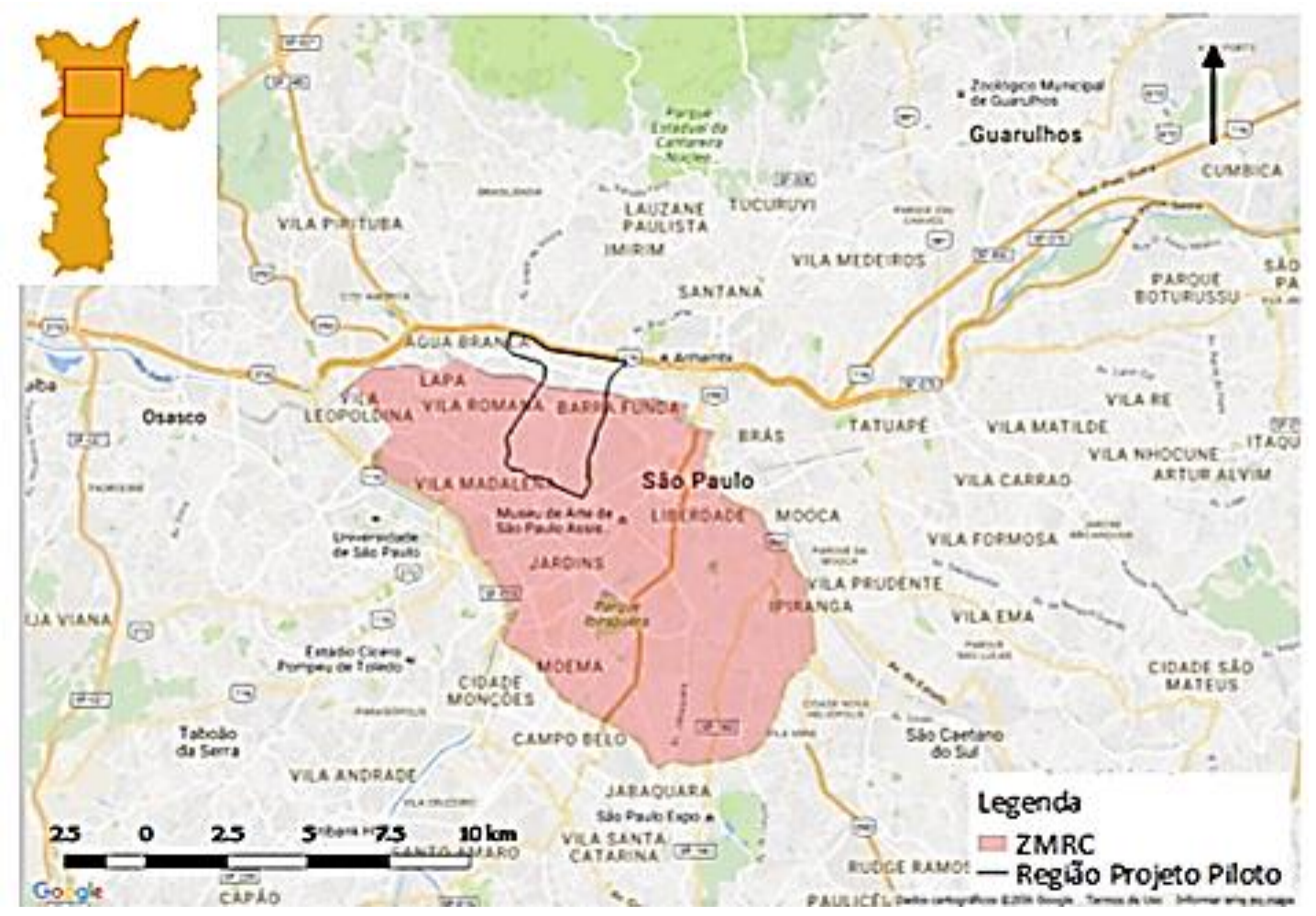

Figura 6 - Região do Projeto Piloto de Entregas Noturnas no município de São Paulo

Um convite foi então enviado pelos representantes do poder público com direcionamento a empresas específicas: shoppings centers, home centers e grandes cadeias do setor varejistas. Esses setores são tidos como grandes geradores de tráfego, e a mudança no horário das entregas de carga nestes estabelecimentos pode surtir efeitos positivos no tráfego urbano, principalmente nos horários de pico.

A partir de Outubro de 2014, com o início do projeto, foram realizados diversos acompanhamentos de rota e entregas nas lojas, com análises do tempo de descarregamento, emissão de ruídos, problemas de segurança, e a percepção dos trabalhadores da loja quanto ao impacto das entregas noturnas na sua rotina operacional. A pesquisa desenvolvida para esta dissertação está relacionada à comparação de aspectos operacionais entre as entregas diurnas (entre às $05 \mathrm{~h}$ e $21 \mathrm{~h}$ ) e entregas noturnas (entre às $21 \mathrm{~h}$ e $05 \mathrm{~h}$ ), do ponto de vista de motoristas e funcionários das empresas recebedoras. 


\subsection{Desenvolvimento e aplicações de pesquisa tipo levantamento de dados em}

projetos de entregas noturnas

A realização de uma survey é de suma importância no sentido de investigar a percepção das facilidades e dificuldades para a realização de entregas noturnas. Para tanto é necessário entrevistar diferentes sujeitos da cadeia de suprimentos para ter uma visão mais global desta política de entregas. A formulação do questionário envolve instrumentos provindos de diversas áreas do conhecimento, entre elas, a estatística, a psicologia e as ciências sociais. Adicionalmente, pode-se dizer que quanto mais rigorosa for empregada a metodologia para a realização da survey mais efetivos serão os resultados (VIEIRA, 2009).

A qualidade de um questionário começa pela efetividade de suas questões. Cosenza e Fowler (2008) alertam para o fato de que as respostas precisam ser medidas, e que essas medidas serão mais confiáveis dependendo do grau de associação entre a construção das questões e as respostas a serem obtidas. Esses autores citam fatores importantes que o responsável por elaborar o questionário deve-se lembrar: a inteligibilidade das questões, a escolha do vocabulário, o ordenamento das questões, os pressupostos embutidos em cada questão, a escala que será trabalhada para obter as respostas.

Para Campanelli (2008), escrever boas questões não é suficiente para maximizar a eficiência do questionário. O tipo de coleta de dados também pode favorecer os resultados da survey, se a entrevista foi realizada presencialmente, por telefone, por internet ou por terceiros. A autora cita dicas de como aperfeiçoar a execução das entrevistas para cada tipo de coleta de dados. Por exemplo, para os casos de telefone, presencialmente ou por terceiros, aspectos relacionados à entonação da voz e uma breve explicação de cada bloco de questões, são relevantes. Para entrevistas presenciais, níveis de detalhe como o olhar e as expressões corporais podem melhorar os resultados.

As entrevistas realizadas durante o projeto de entregas noturnas de Nova York foram realizadas de modo não presencial, com o questionário sendo enviado aos entrevistados previamente, depois as respostas eram enviadas aos pesquisadores. Nos questionários dos recebedores, havia três perguntas com respostas fechadas com o uso da escala de likert, nas quais foram trabalhadas questões associadas às mudanças operacionais decorrentes da mudança do horário de entregas, às vantagens e desvantagens em realizar entregas noturnas e se a loja tinha o interesse em continuar a realizar entregas noturnas. Para os transportadores, 
foram aplicados dois questionários distintos: um direcionado aos administradores da frota e outro para os motoristas. Para os administradores, foram elaboradas 6 perguntas, 4 delas com respostas fechadas na escala likert e 2 perguntas com respostas abertas, cujos aspectos trabalhados foram: as impressões em virtude da execução de entregas noturnas, se os custos aumentaram ou diminuíram, as vantagens e desvantagens em realizar entregas noturnas, e se o administrador gostaria de aderir de forma definitiva às entregas noturnas. Já o questionário dos motoristas foi feito com uma estrutura distinta: 8 perguntas fechadas na escala likert, e 2 perguntas com respostas abertas. Para os motoristas, existiu uma maior variedade nas temáticas: condições do tráfego, condições de estacionamento, nível de estresse, segurança, e as principais vantagens e desvantagens em realizar entregas noturnas (HOLGUÍN-VERAS et al., 2013).

O projeto piloto de entregas noturnas de Londres também contou com a realização de questionários. Entretanto, estes foram realizados antes do início da fase piloto, já que teve o intuito de assinalar os locais mais apropriados para efetuar entregas em horários alternativos, de ponderar quais seriam as ações necessárias de cada stakeholder para viabilizar os descarregamentos noturnos e de enumerar os possíveis problemas subsequentes do projeto piloto de entregas noturnas. Além de duas questões de identificação do respondente, o questionário abrigou 19 perguntas, das quais 5 possuíam respostas dissertativas e 14 respostas fechadas. Dessas 14, 10 eram de alternativas binárias, apenas sim ou não como respostas. O conteúdo do questionário está vinculado ao zoneamento do estabelecimento, frequência do recebimento, tipo de mercadorias comercializadas na loja, tipo do veículo que entrega as mercadorias, qual tipo de equipamento descarrega as mercadorias, como é feita a logística reversa e os principais problemas advindos da realização de entregas noturnas (DOUGLAS et al., 2008).

Com base nesses dois exemplos, essa dissertação tem como proposta, para o projeto de entregas noturnas, selecionar amostras significativas de dois grupos de sujeitos: motoristas e recebedores (que podem ser gerentes, subgerentes, chefes de loja, chefes de operações, ou auxiliares). Para cada sujeito foi elaborado um questionário diferente, de acordo com as funções que este realiza. O comportamento desses sujeitos deve ser estudado antes da elaboração do questionário, com o intuito de garantir a confiabilidade das informações coletadas (AMARAL, 2012). Para tanto, foi investigado na revisão blibliográfica, alguns 
comportamentos desses dois grupos de sujeitos que podem influenciar na maior ou menor aptidão para a adoção das entregas urbanas noturnas.

O conhecimento dos dados de análise deve ser feito minuciosamente, para que a etapa posterior, que corresponde ao tratamento dos dados, ocorra da maneira esperada. Uma análise de estatística descritivas das respostas será feita, inicialmente, para avaliar o quão são diferentes as opiniões dos respondentes. Após a consolidação das medidas de estatísticas básicas e análise de frequência para as variáveis analisadas, foi feito um estudo de análise multivariada de dados, especificamente análise de correspondência (Fávero et al., 2013).

Outro fator importante para a elaboração do questionário é a estratificação das alternativas para as questões fechadas. O número de classes de frequência e a amplitude das mesmas foram elaboradas para cada questão, na qual se buscou adquirir a informação desejada sem tornar cansativa a leitura da pergunta, com um número demasiado de alternativas. Com relação a trabalhar com classes de frequência, Costa Neto (1978) afirma que este procedimento

... corresponde a uma diminuição proposital da precisão com que os dados são computados. Ou seja, propositalmente deixamos de lado uma parcela da informação contida nos dados originais tendo em vista obter uma representação mais adequada.

A estrutura dos questionários seguiu algumas sugestões de Roland (2005), principalmente com relação à escala das respostas. O autor, ao pesquisar como seriam os fretes noturnos londrinos, sugere uma seleção de procedimentos, entre estas estão como elaborar uma planilha de acompanhamento de entregas, como monitorar ruído e, ao que interessa para esta pesquisa, como executar uma survey.

\subsection{População e amostra}

\subsubsection{Motoristas}

A população se refere aos condutores de veículos de carga que trabalham no período noturno no município de São Paulo. Os questionários e entrevistas foram realizadas entre 13/10/2014 e 18/03/2016 com motoristas que entregam carga ao varejo.

A quantidade de motoristas que realiza ou já realizou entregas noturnas no município de São Paulo, ou seja, a população desta etapa da pesquisa pode ser considerada infinita e a 
amostra por conveniência, porém não representativa. Pois esse número não pôde ser calculado com exatidão por falta de dados para calibrar os parâmetros da representatividade da amostra.

\subsubsection{Recebedores}

A população se refere aos trabalhadores envolvidos no recebimento de cargas noturnas, sendo um respondente para cada loja que já executou ou ainda executa entregas noturnas. Ou seja, essa população pode ser considerada como infinita, pois não há a possibilidade de saber, com exatidão, quantas lojas do município de São Paulo recebem mercadorias entre às $21 \mathrm{~h}$ e as $5 \mathrm{~h}$.

As possibilidades de encontrar varejistas dispostos a responder as pesquisas e o prazo de execução dessa pesquisa acadêmica são motivos que levam esses dados a serem trabalhados com um erro de 5\%, nível de confiança em 95\%, o que se refere a 1 desvio padrão sob a distribuição normal. Para o cálculo do tamanho da amostra, será utilizada a fórmula desenvolvida por Barbetta (2002).

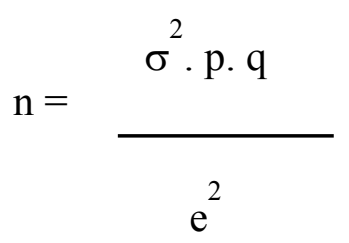

Onde:

$n=$ Tamanho da amostra

$\sigma^{2}=$ Nível de confiança escolhido, expresso em número de desvios-padrão

$\mathrm{p}=$ Percentagem com a qual o fenômeno se verifica

$\mathrm{q}=$ Percentagem complementar $(100-\mathrm{p})$

$\mathrm{e}^{2}=$ Erro máximo permitido

Os parâmetros p e q foram estipulados com base na quantidade de lojas de lojas de duas grandes empresas que participaram do projeto piloto e responderam aos questionários trabalhados nessa dissertação. Em uma delas, do ramo farmacêutico, a quantidade de lojas que faz decarregamento noturno se refere a $36 \%$ do total, e na outra, do ramo de supermercados, a quantidade de lojas que recebe mercadorias no período noturno é de $27 \%$. Ao calcular a média 
entre essas duas empresas, chega-se a $p=31,5$ e $q=68,5$. Ao aplicar a fórmula chega-se a uma amostra de 84 lojas, pertencentes a 17 diferentes empresas do ramo varejista e alimentício.

Das 17 empresas participantes da pesquisa, 16 pertencem à divisão 47 da Classificação Nacional das Atividades Econômicas (CNAE 2.0), denominada de "comércio varejista", enquanto 1 se coloca na divisão 56 da CNAE 2.0, cuja denominação é "restaurantes". Das 17 empresas da divisão varejista, 10 são dos grupos 471 (comércio varejista não-especializado com ênfase em produtos alimentícios), 3 se enquadram no grupo 477 (comércio varejista de produtos farmacêuticos, perfumaria e cosméticos e artigos médicos, ópticos e ortopédicos), 1 no grupo 474 (comércio varejista de material de construção) e 2 no grupo 475 (comércio varejista de equipamentos de informática e comunicação; equipamentos e artigos de uso doméstico). A outra empresa, pertencente ao ramo de restaurantes, é classificada no grupo 561 (restaurantes e outros serviços de alimentação e bebidas).

Das 17 empresas participantes, 9 participaram do projeto-piloto e estão entre as 60 empresas do ramo de bens de consumo que mais faturaram no ano de 2012, sendo que o faturamento dessas 9 empresas correponde a aproximadamente $10 \%$ do faturamento total das empresas que comercializam bens de consumo (IBEVAR, 2013). Já as outras 8 empresas respondentes são de pequeno porte.

Com relação às empresas correspondentes ao ramo 471, duas delas estão entre as 15 empresas deste grupo que mais faturaram no ano de 2012, somando o faturamento dessas duas empresas chega-se a um percentual de $38 \%$ das empresas que mais faturaram neste respectivo ano, segundo o IBEVAR (2013). A empresa respondente do grupo 475, com foco no comércio de móveis e eletrônicos, possui faturamento de $35 \%$ em relação à soma das cinco empresas desse grupo que mais faturaram. Já a empresa do grupo 475, com foco na venda de artigos de vestuário, possui um faturamento equivalente a $21 \%$ da soma das cinco empresas que mais faturaram em 2012. As três empresas respondentes do ramo 477 faturaram o equivalente a $72 \%$ das cinco que mais lucraram em 2012. A empresa do ramo de construção faturou o equivalente a $23 \%$ das cinco do mesmo ramo que mais faturaram em 2012. Já a corporação do ramo de restaurante que respondeu a esta pesquisa, faturou o equivalente a $12 \%$ da soma do faturamento das cinco maiores. As outras quatro empresas do ramo de comércio varejista nãoespecializado são de pequeno porte, e os respectivos dados de faturamento não estão disponíveis.

A Tabela 2 resume as principais informações sobre a descrição da amostra. 
Tabela 2 - Descrição da amostra das empresas varejistas participantes da pesquisa

\begin{tabular}{ccccc}
\hline $\begin{array}{l}\text { Grupo } \\
\text { CNAE 2.0 }\end{array}$ & $\begin{array}{c}\text { Número } \\
\text { empresas } \\
\text { amostra }\end{array}$ & $\begin{array}{c}\text { de } \\
\text { da }\end{array}$ & $\begin{array}{l}\text { Número de empresas da } \\
\text { amostra na classificação do } \\
\text { IBEVAR }\end{array}$ & Faturamento relativo \\
\hline 471 & 10 & 2 & $45 \%$ das 5 maiores \\
477 & 3 & 3 & $72 \%$ das 5 maiores \\
475 & 1 & 1 & $35 \%$ das 5 maiores \\
475 & 1 & 1 & $21 \%$ das 5 maiores \\
474 & 1 & 1 & $23 \%$ das 5 maiores \\
561 & 1 & 1 & $12 \%$ das 5 maiores \\
\hline
\end{tabular}

Pela Tabela 2, percebe-se que a amostra é representativa, segundo o ranqueamento IBEVAR (2013). Embora das 10 empresas do grupo 471 apenas duas estejam classificadas no IBEVAR (2013), estas representam cerca de 45\% do faturamento entre as 5 maiores empresas do setor.

\subsection{Elaboração do questionário}

\subsubsection{Questionário dos motoristas}

O primeiro bloco do questionário para os motoristas (Apêndice A) possui o objetivo de identificar o respondente. $\mathrm{O}$ segundo bloco detalha os aspectos relacionados às entregas, para avaliar os fatores que aumentam a eficiência das entregas urbanas, e porque as entregas noturnas podem contribuir para melhorar as entregas no meio urbano. As multas de estacionamento e de restrição ao tamanho do caminhão, as dificuldades de estacionar, o nível de estresse, a pontualidade, as possibilidades de utilizar caminhões maiores são tidos como fatores favoráveis para colocar os descarregamentos noturnos em prática. O tipo de caminhão pode explanar se a vantagem em utilizar grandes caminhões está sendo colocada em prática. Por isso, para cada motorista entrevistado, identificou-se o tipo de caminhão que fizera a entrega.

O terceiro bloco procura avaliar quais ações devem ser tomadas junto ao poder público para que a descarregamento ocorra de forma mais eficaz e efetiva. As condições sobre 
iluminação pública, a importância em demarcar vagas de carga/descarga e a importância em melhorar as calçadas são as temáticas que encerram este bloco.

O quarto bloco assinala os principais problemas de estruturas nas lojas recebedoras, e verifica a preferência do motorista em realizar entregas noturnas com a assintência da loja ou sem a assistência da loja.

O quinto bloco interroga se há problemas com segurança e com a emissão de ruídos durante a descarga noturna, além de abrir espaço para comentários gerais sobre o tema.

O Quadro 4 sintetiza as variáveis de análise a serem trabalhadas nos questionários dos motoristas, e os principais autores que as referenciam em suas pesquisas.

\begin{tabular}{|l|l|}
\hline \multicolumn{2}{|c|}{ MOTORISTAS } \\
\hline Variável de análise & Referência \\
\hline Jornada de trabalho & Quiroga (2000) \\
\hline $\begin{array}{l}\text { Tempo médio para encontrar uma vaga para o } \\
\text { descarregamento }\end{array}$ & Stathopoulos et al. (2011) \\
\hline Tipo de caminhão & Mercadona (2010) \\
\hline Multas & Holguín-Veras (2013) \\
\hline Nível de estresse & Holguín-Veras (2014) \\
\hline Segurança & Noel et al. (1980) \\
\hline Condições de iluminação & Santos (2005) \\
\hline Estrutura de recebimento & Porter et al. (2012) \\
\hline Pontualidade & Ainge et al. (2007) \\
\hline
\end{tabular}

Quadro 4 - Variáveis de análise para os motoristas

O questionário para motoristas foi realizado durante os acompanhamentos de rota junto ao CISLog/USP (Centro de Inovação em Sistemas Logísticos da Universidade de São Paulo), ou em datas marcadas para realizá-las no inteiror do Centro de Distribuição das empresas participantes, ou através do contato direto com outras empresas varejistas que executam entregas noturnas. 


\subsubsection{Questionário dos recebedores}

Com base nas pesquisas tipo levantamento desenvolvidas para entregas noturnas e nos trabalhos de campo realizados durante o projeto piloto de entregas noturnas de São Paulo, foi produzido o questionário para ser aplicado aos recebedores.

O questionário se inicia no bloco 1 , com a caracterização do respondente e do respectivo estabelecimento comercial. As perguntas deste bloco foram colocadas no sentido de conhecer alguns atributos da empresa, para entender de que forma as entregas noturnas podem contribuir com a melhoria das operações. Posteriormente, as respostas deste bloco serão utilizadas para identificar perfis de empresas com mais facilidade para realizar entregas noturnas.

O bloco 2 indaga sobre aspectos relacionados à organização geral da loja. O bloco 3 procura identificar a importância de algumas ações do poder público para viabilizar e maximizar os efeitos positivos das entregas noturnas. O bloco 4 tem a meta de evidenciar as condições de recebimento e assinalar a necessidade de melhoria em algumas estruturas para efetuar o descarregamento com mais agilidade, o que maximiza a eficiência e evita riscos de assaltos. Com relação à segurança, a iluminação pública é um importante fator para garantir a segurança do patrimônio e da sociedade (SANTOS, 2005), e diante disso, foi incorporada uma questão que aborda os problemas da iluminação públicas nos locais de recebimento.

O bloco 5, denominado "Desempenho logístico da empresa" procura comparar alguns procedimentos operacionais com as entregas sendo feitas no período diurno e com as entregas sendo feitas no período da noite. O bloco 6 relaciona a execução dos descarregamentos noturnos com os principais problemas, relacionados à sociedade, que foram identificados nos trabalhos de campo e na revisão bibliográfica.

O Quadro 5 identifica quais variáveis foram trabalhadas no questionário destinado aos recebedores e relaciona com a referência bibliográfica da temática trabalhada.

\begin{tabular}{|l|l|}
\hline \multicolumn{2}{|c|}{ RECEBEDORES } \\
\hline Variável de análise & \multicolumn{1}{c|}{ Referência } \\
\hline Horário de maior movimentação de clientes na loja & Holguín-Veras et al. (2010) \\
\hline Melhor horário para alocar mercadorias nas gôndolas & Holguín-Veras et al. (2010) \\
\hline Nível de estresse & Holguín-Veras et al. (2010) \\
\hline Pontualidade & Douglas et al. (2008) \\
\hline
\end{tabular}




\begin{tabular}{|l|l|} 
Estrutura de recebimento & Porter et al. (2012) \\
\hline Segurança & Noel et al. (1980) \\
\hline Ruído & Ainge et al. (2007) \\
\hline Qualidade de atendimento ao cliente & Holguín-Veras et al. (2010) \\
\hline Agilidade para conferir e estocar & Holguín-Veras et al. (2010) \\
\hline Ações do poder público & Santos (2005) e Holguín-Veras et al. (2010) \\
\hline
\end{tabular}

Quadro 5 - Variáveis de análise para o questionário dos recebedores

A aplicação dos questionários aos recebedores foi feita presencialmente, após agendamento prévio com os responsáveis por autorizar a execução das entrevistas. Esta forma de aplicação assegura qualidade nas respostas (VIEIRA, 2009).

\subsection{Resumo das variáveis dos questionários}

Para realizar o tratamento estatístico dos dados dos questionários, é necessário conhecer os tipos de variáveis contidos nos questionários e sua descrição gráfica. A definição dessas características é fundamental para escolher o tipo de tratamento de dados para extrair as informações desejadas (COSTA NETO, 1978). Para tanto, o Quadro 6 esclarece estas carcterísticas para as variáveis contidas nos questionários.

\begin{tabular}{|c|c|c|c|}
\hline Variável & Tipo & Escala & Autor \\
\hline \multicolumn{4}{|l|}{ Motoristas } \\
\hline Tempo de rota & Quantitativa & Contínua & Holguín-Veras et al. (2010) \\
\hline Tempo para estacionar & Quantitativa & Contínua & Mercadona (2010) \\
\hline Tipos de multa & Qualitativa & Categórica & Stathopoulos et al. (2011) \\
\hline Nível de estresse & Qualitativa & Binária & Holguín-Veras et al. (2010) \\
\hline Pontualidade & Qualitativa & Binária & Ainge et al. (2007) \\
\hline Segurança & Binária & Binária & Noel et al. (1980) \\
\hline Ações do poder público & Qualitativa & Likert & $\begin{array}{l}\text { Santos (2005); Holguín Veras } \\
\text { et al. (2010) }\end{array}$ \\
\hline Ruído & Qualitativa & Binária & Douglas et al. (2008) \\
\hline Estruturas de recebimento & Qualitativa & Binária & Porter et al. (2012) \\
\hline \multicolumn{4}{|l|}{ Recebedor } \\
\hline $\begin{array}{l}\text { Horário de maior movimentação de } \\
\text { clientes }\end{array}$ & Qualitativa & Categórica & Holguín-Veras et al. (2010) \\
\hline $\begin{array}{l}\text { Melhor horário para alocar mercadorias } \\
\text { nas gôndolas }\end{array}$ & Qualitativa & Categórica & Holguín-Veras et al. (2010) \\
\hline
\end{tabular}




\begin{tabular}{|l|l|l|l|} 
Estruturas de recebimento & Qualitativa & Binária & Porter et al. (2012) \\
\hline Pontualidade & Binária & Discreta & Ainge et al. (2007) \\
\hline Ações do poder público & Qualitativa & Likert & $\begin{array}{l}\text { Santos (2005); Holguín Veras } \\
\text { et al. (2010) }\end{array}$ \\
\hline Agilidade para conferir e estocar & Qualitativa & Binária & Holguín-Veras et al. (2010) \\
\hline Qualidade de atendimento ao cliente & Qualitativa & Binária & Holguín-Veras et al. (2010) \\
\hline Nível de estresse do estoquista & Qualitativa & Binária & Holguín-Veras et al. (2010) \\
\hline Segurança & Qualitativa & Binária & Noel et al. (1980) \\
\hline Ruído & Qualitativa & Binária & Douglas et al. (2008) \\
\hline
\end{tabular}

Quadro 6 - Sistematização das variáveis trabalhadas nos questionários

\subsection{Métodos de análise}

Primeiramente foi utilizado estatística descritiva, com análise de frequência e algumas medidas de posição e dispersão, como média, mediana e desvio padrão. Em seguida, o método de estatística multivariada foi aplicado para obter informações adicionais através dos dados dos questionários. A análise de correspondência foi utilizada em dois momentos: para identificar as variáveis mais críticas para a eficiência das entregas noturnas, e para assinalar o maior problema para a execução das entregas noturnas.

Desta forma, foram selecionadas variáveis contidas nos questionários que interferem na eficiência das entregas e variáveis que são problemáticas para as empresas que decidem executar as entregas noturnas. As variáveis de cada questionário utilizadas em cada um dos momentos estão no Quadro 7.

\begin{tabular}{|l|l|l|}
\hline Fatores & \multicolumn{1}{|c|}{ Motoristas } & \multicolumn{1}{c|}{ Recebedores } \\
\hline \multirow{2}{*}{ Eficiência } & $\begin{array}{l}\text { Pontualidade, fila de caminhões, } \\
\text { necessidade em demarcar vagas de } \\
\text { carga/descarga, falta de vagas para } \\
\text { estacionar. }\end{array}$ & $\begin{array}{l}\text { Pontualidade, agilidade para armazenar e } \\
\text { conferir, qualidade de atendimento ao cliente, } \\
\text { fila de caminhões, necessidade em demarcar } \\
\text { vagas de carga/descarga, falta de vagas para } \\
\text { estacionar. }\end{array}$ \\
\hline Problemas & Ruídos, segurança, iluminação & Ruídos, segurança, iluminação pública. \\
\hline
\end{tabular}

Quadro 7 - Possível relação entre variáveis dos questionários e os fatores de análise propostos 
A análise de correspondência é uma técnica utilizada para assinalar quais variáveis de análise estão próximas umas das outras, a qual fornece um mapa perceptual, que demonstra aproximação das variáveis. Consiste em uma técnica de exploração de dados de variáveis qualitativas (FÁVERO et al, 2009).

Neste método, as variáveis que estão mais próximas mantêm associações mais fortes, e elas podem ser analisadas separadamente, ou seja, verficar a distância de cada uma delas em relação a cada uma das outras variáveis (FÁVERO et al., 2009). Um dos pressupostos para a aplicação da análise de correspondência é a realização de testes de $\chi^{2}$ para averiguar se as variáveis possuem relação de dependência (SARTORIO, 2008). Mingoti (2005) destaca as fortes relações entre o teste de $\chi^{2}$ e a análise de correspondência, pois as distâncias físicas entre as variáveis deste mapa perceptual são influenciadas pelos resultados deste teste, de forma que as distâncias aferidas no teste do $\chi^{2}$ colocam as variáveis em projeções ortogonais em um espaço dimensional. 


\section{Apresentação e análise dos dados}

A análise dos resultados demonstra como as entregas noturnas podem influenciar na logística urbana de uma grande cidade, visto que o procedimento logístico noturno tem sido adotado internacionalmente como uma prática que pode reduzir o preço dos fretes e agilizar as entregas urbanas (BH TRANS, 2016).

A partir dos dados coletados, foram utilizados os seguintes métodos de pesquisa: primeiramente por meio de estatística descritiva, principalmente análise de frequência (seção 4.1); e o método de análise de correspondência foi aplicado com o objetivo de aprofundar a análise dos dados e endossar os principais aspectos (seção 4.3).

Posteriormente, é apresentada uma análise comparativa através da discussão dos projetos à luz da revisão da literatura e os resultados da apresentação dos dados referente às seções 4.1, 4.2 e 4.3 .

A seguir, será analisado os resultados referentes aos motorias e posteriormente os dados dos varejistas.

\subsection{Análise descritiva dos dados dos motoristas}

\subsubsection{Perfil do respondente}

A pesquisa mostra um tempo de trabalho dos motoristas entrevistados relativamente alto, embora um desvio-padrão também alto. Porém, pela mediana, pode-se inferir que 50\% dos motoristas possui mais de 10 anos de experiência no cargo (vide Tabela 3).

Tabela 3 - Medidas estatísticas para o tempo de trabalho do motorista

\begin{tabular}{lr}
\hline Tempo de trabalho como motorista (anos) \\
\hline Média & 11.61 \\
Mediana & 10.0 \\
Desvio padrão & 9.17 \\
\hline
\end{tabular}




\subsubsection{Caracterização do trabalho e das entregas}

A seguir são apresentadas análise de dados sobre alguns aspectos dos trabalhos do motorista e algumas condições sobre o ato da entrega. As variáveis analisadas são: tempo de rota (para os períodos diurno e noturno) e tempo médio gasto para achar uma vaga para descarregar (para os períodos diurno e noturno), preferência de horário para trabalhar (diurno e noturno), pontualidade (diurno e noturno), nível de estresse do horário de trabalho (diurno e noturno), tipo de multa mais recorrente, tipo de veículo utilizado.

Aproximadamente $70 \%$ dos motoristas declararam preferir trabalhar a noite, e isto pode estar atrelado ao nível de estresse decorrente da distribuição de cargas. Foi solicitado para que os motoristas respondessem se sentem mais estressados trabalhando de dia ou de noite, aproximadamente $80 \%$ sentem maior nível de estresse trabalhando no período diurno. Alguns motoristas relataram que se sentem mais estressados trabalhando de dia, mas preferem continuar executando as entregas de carga de dia por questões familiares. Entre os motivos citados pelos motoristas que tornam o período diurno mais estressante para trabalhar estão o trânsito, o calor e a dificuldade para encontrar uma vaga para descarregar.

O nível de estresse de um trabalhador pode ter efeitos diferentes de pessoa para pessoa, entretanto o aumento de estresse no ambiente de trabalho pode afetar o sistema circulatório, o sistema nervoso, que por sua vez atingem o comportamento das pessoas, levando a atitudes agressivas ou depressivas (GREENBERG, 2002). Quanto ao trabalho do motorista, diversos aspectos contribuem para explicar o estresse, por exemplo, ruídos, condições mecânicas do veículo, vibrações, esforços repetitivos, postura ao dirigir (SILVA, 2014). Além desses fatores, as condições do trânsito também influenciam nas condições de saúde emocional e física dos mostoristas, pois estes precisam de uma atenção initerrupta para evitar acidentes (BATTISTON; CRUZ; HOFFMAN, 2006), além de possuírem a obrigação de executar todas as entregas em tempo hábil, sob a condição de terem seus salários reduzidos devido ao não cumprimento de alguma entrega. Um dos motoristas entrevistados relatou ter sofrido um infarto durante o trabalho, o que foi causado pelo excesso de trânsito, levando o trabalhador a não conseguir efetuar todas as entregas e teve seu bônus de produtividade, que é calculado de acordo com a porcentagem de entregas executadas no tempo correto, reduzido consideravelmente. Segundo este mesmo motorista, "este tipo de contrato de produtividade 
de acordo o cumprimento do descarregamento na janela de entrega pode levar o motorista a exceder o limite de velocidade, podendo aumentar o risco de acidentes".

Quanto ao período noturno, um dos motivos que aumenta o nível de estresse dos motoristas é a reação da sociedade perante aos ruídos emitidos no descarregamento. Foram relatadas agressões de vizinhos do estabelecimento receptor ao atirarem objetos nos trabalhadores envolvidos na operação logística, sendo que, em casos mais graves, o descarregamento teve de ser interrompido e só foi finalizado no dia seguinte em horas comerciais. Os motoristas, que vivenciaram essa situação, tiveram que esperar a continuidade do descarregamento dentro da doca da loja. Outra questão que traz preocupação aos motoristas para realizar as entregas urbanas no período noturno é a segurança pública. Estes se sentem mais apreensivos no período noturno, já normalmente que as ruas ficam mais vazias, aumentando a sensação de insegurança.

Outros fatores que são substancias para diferenciar as entregas diurnas das entregas noturnas são: tempo de rota e tempo para encontrar uma vaga para estacionar. Vale ressaltar que a diminuição do tempo de entrega é um importante fator que pode melhorar a eficiência da logística urbana (DABLANC, 2007), e a dificuldade de estacionar pode influenciar negativamente no sistema de distribuição de carga urbana (ZAMBUZI, 2015).

A Tabela 4 mostra um tempo de rota médio no período diurno acima de 9 horas, com uma mediana de aproximadamente $9 \mathrm{~h} 30 \mathrm{~min}$, ou seja, pode-se dizer que pelo menos $50 \%$ dos motoristas dirigem 9h30min por dia. O desvio-padrão relativamente baixo infere que o tempo de rota no período diurno não é menor do que 6 horas diárias. O tempo médio para achar uma vaga para descarregar está acima de 47 minutos, enquanto pela mediana pode-se inferir que 50\% dos motoristas demoram 40 minutos para estacionar. O desvio-padrão do tempo para estacionar também é alto, isso mostra que todos os motoristas demoram mais de 12 minutos para encontrar uma vaga para estacionar no período diurno. 
Tabela 4 - Tempo de rota e tempo médio para encontrar uma vaga para descarregar no período diurno

\begin{tabular}{lcc}
\hline & Tempo de rota & $\begin{array}{c}\text { Tempo para achar vaga para } \\
\text { descarregar }\end{array}$ \\
\hline Unidades de medida & Horas/dia & Minutos \\
\hline Média & 9.15 & 47.83 \\
Mediana & 9.5 & 40 \\
Desvio padrão & 3.19 & 35.73 \\
\hline
\end{tabular}

A Tabela 5 traz os dados de tempo de rota e de tempo para achar uma vaga para descarregar no período noturno. Com uma média de aproximadamente 4h30min, mediana de 4 horas e desvio-padrão de 2 horas, o tempo de rota noturno não deve exceder 6 horas. O tempo para achar uma vaga para descarregar tem uma média de aproximadamente 11 minutos, com mediana de 15 minutos e desvio-padrão de 10 minutos e meio. Este tempo para estacionar pode ser considerado alto para o período noturno, pois muitos dos motoristas entrevistados realizam entregas em supermercados próximos a bares e restaurantes, o que dificulta para encontrar uma vaga para estacionar.

Tabela 5 - Tempo de rota e tempo médio para encontrar uma vaga para descarregar no período noturno

Tempo de rota Tempo para achar vaga para decarregar

\begin{tabular}{lcc}
\hline Unidades de medida & Horas/dia & Minutos \\
\hline Média & 4.4 & 11.82 \\
Mediana & 4 & 15 \\
Desvio padrão & 2.02 & 10.31 \\
\hline
\end{tabular}

As Tabelas 4 e 5 mostram que há uma influência do tempo para encontrar uma vaga para o descarregamento no tempo de rota, já que o no período diurno o tempo demandado para achar uma vaga descarregar é mais alto que no período noturno, fato que refletirá o tempo total da rota de entregas.

Além da dificuldade em encontrar uma vaga para estacionar no período diurno, a cobrança de tickets Zona Azul para estacionar nas vagas de carga e descarga no período diurno eleva o custo da entrega, o que foi citado por dois motoristas. A cobrança de tickets de 
estacionamento é um dos fatores que encarecem o custo das entregas e pode induzir a realização de entregas no período noturno (IYLER, 2010).

O principal contratempo em estacionar no período noturno, de acordo com dois motoristas, ocorre onde a entrega é feita em locais com muitos bares e restaurantes nas proximidades, chegando a situações em que haviam carros de clientes estacionados nas vagas destinadas para carga e descarga.

A pontualidade das entregas urbanas também é diferente quando ocorrem no período diurno ou no período noturno, pois menor tempo de rota no período noturno reflete mais eficiência nas operações logísticas (HOLGUÍN-VERAS et al., 2014) e mais confiabilidade quanto ao horário de chegada dos caminhões (DOUGLAS et al., 2008). Um motorista relatou que o trânsito faz com que atrase a chegada do caminhão nas lojas, e muitas vezes, depois do fechamento da janela de recebimento de mercadorias da loja, fator que leva a não concretizar a entrega dos produtos. Para $71 \%$ dos motoristas as entregas urbanas são mais pontuais se forem realizadas no período noturno.

Outro fator que pode contribuir com a eficiência das entregas urbanas é o tipo de caminhão (MERCADONA, 2010). Os caminhões maiores (toco e truck) e as carretas conseguem abrigar mais pedidos, o que economiza combustível e aumenta a eficiência das entregas urbanas. Entretanto, eles só podem circular, no período noturno, em certos locais, principalmente nas regiões centrais da cidade, onde há mais intensidade na movimentação de pessoas e mercadorias.

A Figura 7 mostra os tipos de veículo, por quantidade, usados por motoristas nas entregas noturnas. 


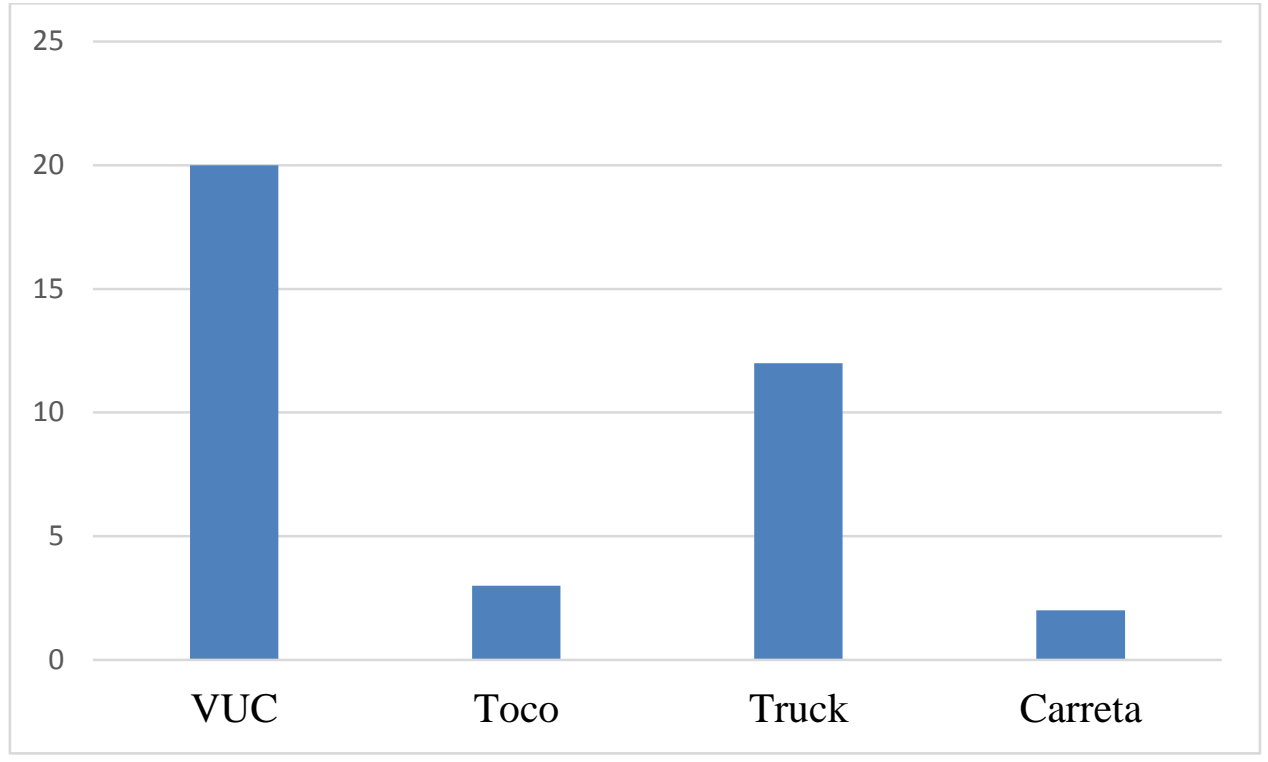

Figura 7 - Tipo de caminhão utilizado no período noturno

Ao observar que mais da metade dos veículos utilizados no período noturno são VUCs, pode-se afirmar que algumas empresas não aproveitam a vantagem da permissão da circulação de veículos grandes (toco, truck, carreta) no período noturno, um dos pressupostos de que as entregas noturnas melhoram a eficiência da distribuição de cargas (HOLGUÍN-VERAS et al. 2013).

Com relação às multas, dos 100 motoristas entrevistados, 74 declararam prejuízos financeiros decorrentes da aplicação de multas, cujos motivos principais são estacionar em vaga proibida, e a restrição ao tráfego de caminhões na ZMRC (Zona Máxima de Restrição de Circulação), conforme evidencia a Figura 8. Percebe-se Percebe-se pela Figura 8 que a maioria das multas se refere a estacionar em "vaga proibida". Além das restrições de circulação, outros 7 (sete) motoristas declararam espontaneamente que sofrem mais multas por velocidade, e 2 (dois) afirmaram de maneira espontânea que sofrem mais penalidade por rodízio. 


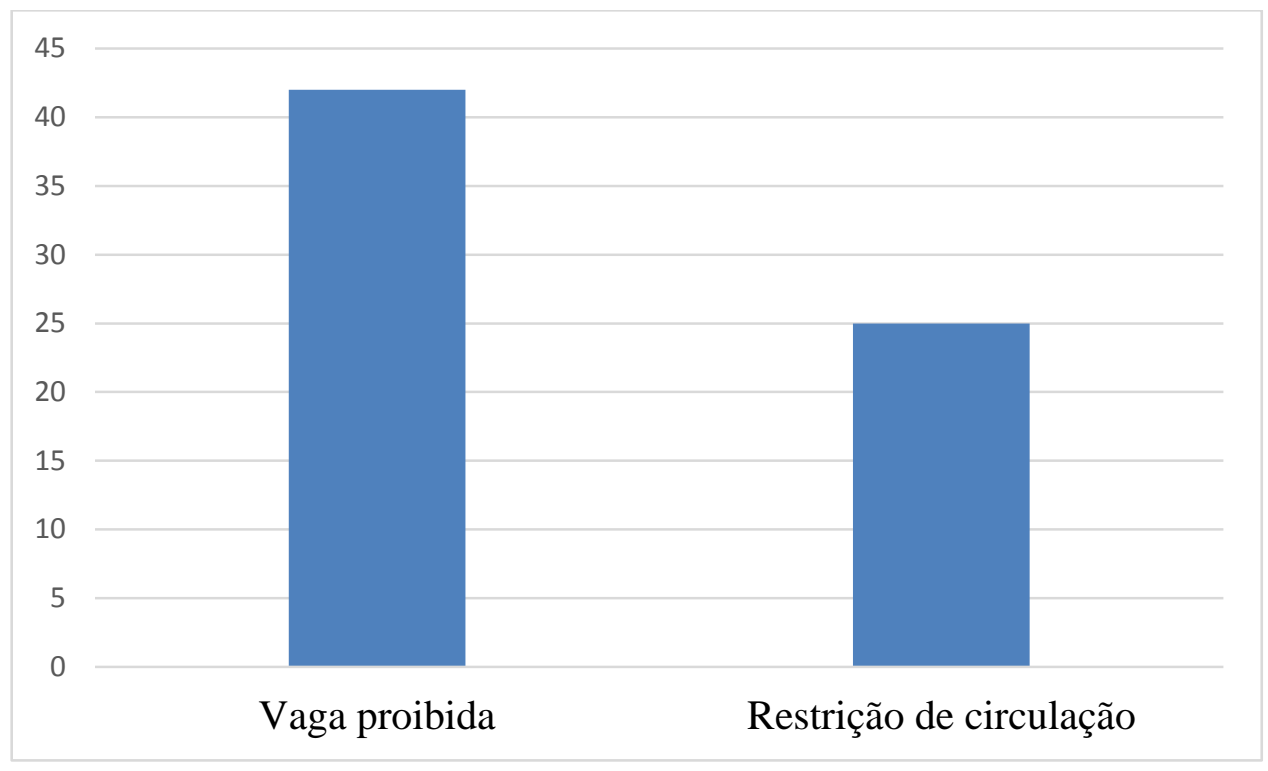

Figura 8-Quantidades de multas sofridas por motoristas

Com as entregas sendo realizadas à noite, há a possibilidade de eliminar as multas por restrição de circulação, já que esta norma proíbe os caminhões maiores de circular entre $05 \mathrm{~h}$ e 20h. As multas relacionadas ao ato de estacionar em local proibido também podem ser reduzidas, pois as ruas se encontram mais vazias (CET, 2014), e há menos circulação de pedestres, o que facilita o estacionamento e o descarregamento. Ou seja, com exceção das multas por velocidade no período noturno, pode-se evitar os outros tipos. Neste momento, é válido recordar que durante o período noturno não é cobrado o ticket de estacionamento no município de São Paulo, o que também reduz o custo das entregas. Pode-se considerar, então, que há menos possibilidades de haver penalização aos motoristas e empresas envolvidos em operações logísticas noturnas.

\subsubsection{Caracterização das ações do poder público}

As seguintes variáveis de análise quanto às ações do poder público estão presentes neste bloco: condições de iluminação pública nas proximidades da doca, importância em demarcar vagas de carga/descarga e melhoria das calçadas. O poder público é um importante sujeito para a otimização da movimentação de carga urbana, fornecendo uma estrutura adequada com vistas a reduzir os custos logísticos (DUTRA, 2004). 
Quanto à iluminação pública, 46 motoristas entendem que as condições de iluminação pública são satisfatórias, 10 a consideram regular, e 26 entendem que as condições desta estrutura de análise não são satisfatórias como mostra a Figura 9.

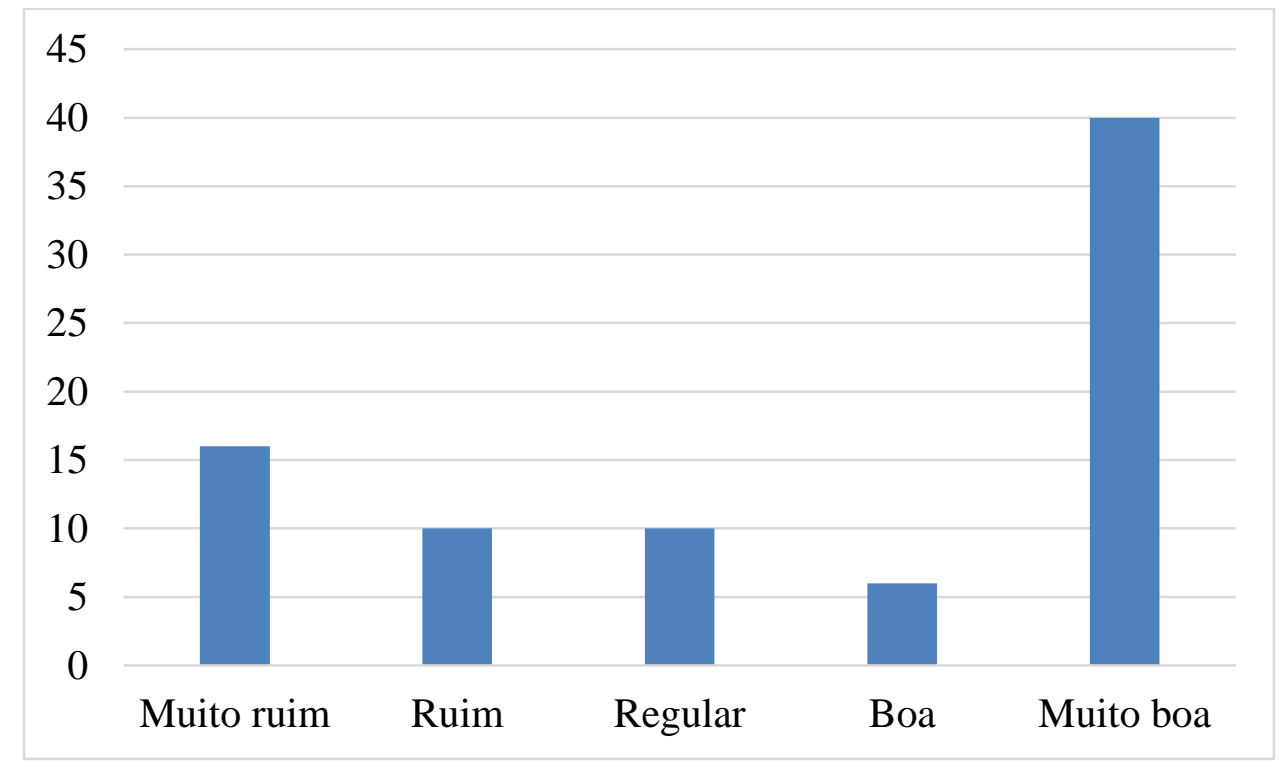

Figura 9 - Número de respostas para as condições de iluminação pública

Alguns motoristas que consideraram a iluminação pública muito ruim citaram os lugares mais carentes de postes de luz: o Capão Redondo, bairro da zona sul de São Paulo, foi citado três vezes. As outras localidades problemáticas, neste quesito, citadas pelos motoristas, são: Jardins, Cotia, região do ABCD paulista (Santo André, São Bernardo do Campo, São Caetano e Diadema), Brás, Mooca, Osasco, extremo da Zona Leste de São Paulo, e extremo da Zona Norte de São Paulo. Percebe-se que todas as localidades, com exceção dos Jardins, se encontram em áreas periféricas, o que reflete uma realidade dicotômica entre as áreas centrais e a periferia (LEFEBVRE, 2011)

Os problemas em estacionar durante o dia são uma unanimidade entre os motoristas, pois todos que responderam à pergunta sobre demarcar vagas de carga e descarga, disserem que esta ação do poder público é muito importante para agilizar o descarregamento. Não só demarcar as vagas de carga e descarga, mas também fiscalizá-las e punir os veículos que estacionam indevidamente nas mesmas. É função do poder público administrar as vagas de estacionamento de carga e descarga para atingir uma logística urbana mais sustentável (TANIGUCHI et al., 2014). 
Os motoristas relataram que buracos e desnivelamentos em calçadas dificultam o trabalho com transpaletes, ou mesmo ao carregar manualmente caixas com mercadorias. Entre os prejuízos decorrentes da má conservação de calçadas no processo de descarregamento, os motoristas destacaram os seguintes: avaria da mercadoria, danificação da paleteira, risco de acidentes. Um motorista relatou "eu estava com uma pilha de caixas nas mãos, o que o me impossibilitava de enxergar os buracos na calçada, o que me levou a pisar em um buraco, torcer o tornozelo e deixar as caixas caírem no chão". A necessidade de melhorar as calçadas é refletida pela unanimidade de resposta dos motoristas, os 57 que opiniram sobre este tema consideram muito importante melhorar as calçadas. Assim como o fizeram para a iluminação pública, os motoristas citaram as áreas cujas calçadas se encontram em mal estado de conservação: o centro de São Paulo foi citado duas vezes, o bairro do Capão Redondo (citado duas vezes), Itapecirica da Serra e Embu-Guaçu.

\subsubsection{Caracterização da estrutura de recebimento}

Quanto à estrutura de recebimento, as variáveis de análise são: presença de trabalhadores da loja durante o descarregamento noturno, presença de degraus e porta estreita, se há a formação de fila de caminhões para descarregar e as dificuldades ou questões burocráticas para acessar o ponto de entrega.

Foi analisada a forma de realizar entregas noturnas: assistida (com auxílio da empresa recebedora) ou não-assistida (sem o auxílio da empresa recebedora). Dos 56 motoristas que responderam a esta pergunta, apenas 13 motoristas (23\%) preferem realizar entregas sem a assistência da loja presente (Figura 10), pois os casos de divergências quanto a quantidade de produtos seriam de difícil resolução, visto que não há relações de confiança consolidadas entre operadores logísticos e empresas recebedoras, corroborando com Vieira, Carvalho e Fransoo (2015), sobre a falta de colaboração entre recebedores e entregadores. Os motoristas que responderam favoravelmente às entregas não assistidas, relataram que este tipo de entrega é mais ágil e melhora o desempenho logístico do roteiro de entregas. Um destes motoristas favoráveis às entregas não-assistidas, explicou que este tipo de entrega é mais seguro, pois ocorre de maneira mais rápida. 


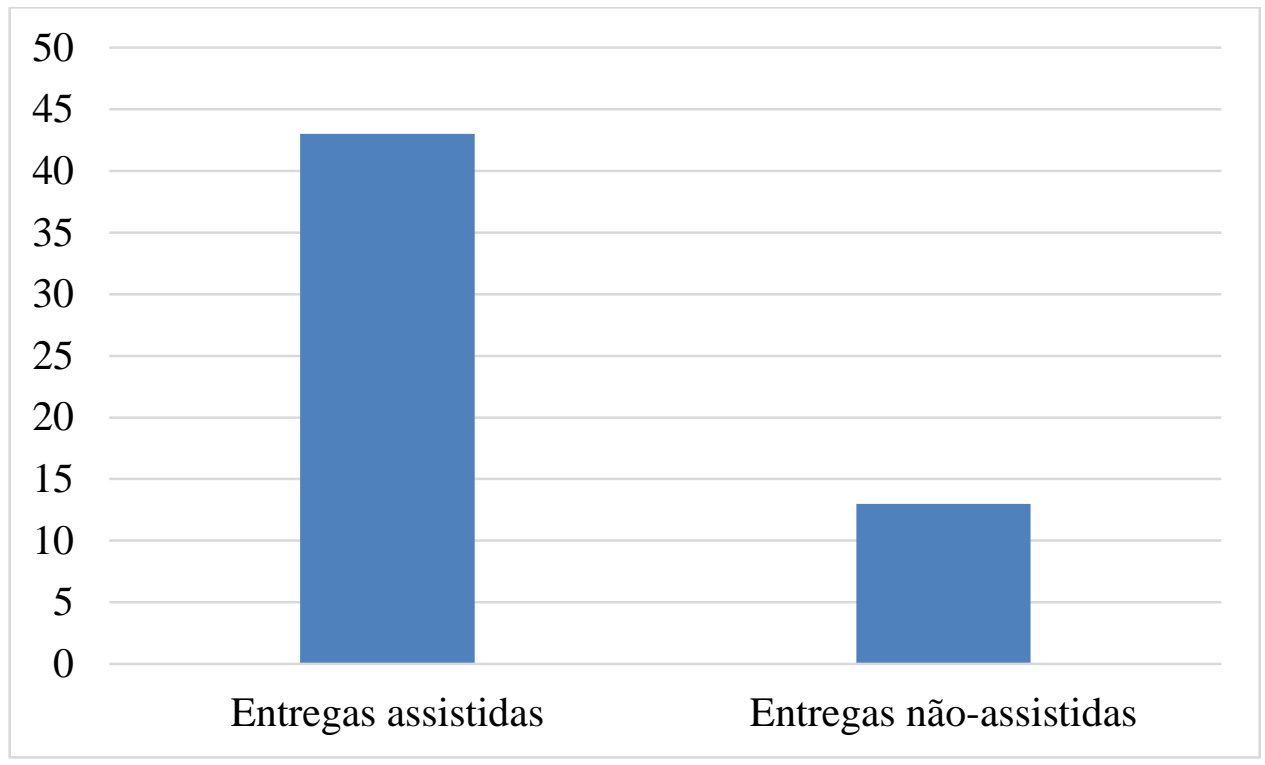

Figura 10 - Número de respostas para a preferência do tipo de entrega noturna

As estruturas citadas para avaliação foram: excesso de degraus, porta estreita, fila de caminhões e dificuldade em acessar o ponto de entrega por questões administrativas. Todos os motoristas, que responderam a estas perguntas, relataram que realizam entregas frequentemente em lojas que possuem problemas em quase todas estruturas citadas. Outros dois motoristas ponderaram que cerca de $80 \%$ ou $90 \%$ das lojas recebedoras possuem problemas na configuração da estrutura de recebimento das lojas.

O excesso de degraus foi citado como um motivo que atrasa as entregas e gera cansaço físico em motoristas e ajudantes, além de ser um dos problemas mais recorrentes nas condições de armazenagem das lojas. Dois motoristas relataram que se não bastasse a quantidade de degraus nas lojas, em algumas delas estes são estreitos e escorregadios, o que pode gerar acidentes e avariar as mercadorias. Dos 57 motoristas que responderam a esta pergunta, 52 $(91,2 \%)$ relataram realizar entregas frequentemente em lojas com excesso de degraus.

Durante os trabalhos de campo executados no projeto piloto de entregas noturnas, foi observado que portas com a largura estreita dificulta a passagem das caixas ou paletes, contribuindo para elevar o tempo de descarregamento, e tratando-se de entregas noturnas, espera-se que as descargas sejam mais ágeis para evitar riscos de assaltos. 52 (91,2\%) motoristas, dos 57 respondentes, relataram que descarregam frequentemente em locais com portas com largura reduzida. Adicionalmente, alguns motoristas disseram que entregam em lojas com corredores estreitos, com o teto baixo, o que contribui para os riscos de acidentes. 
A fila de caminhões para efetuar o descarregamento também é citada como um motivo favorável a realizar alguns fretes durante a noite, pois, desta forma, alguns caminhões passariam a descarregar a noite, e as filas de caminhões durante o dia seriam reduzidas, e o descarregamento agilizado. Todos os motoristas disseram que todos os dias enfrentam fila de caminhões.

$\mathrm{O}$ ato de ser barrado em alguma portaria por questões administrativas ou burocráticas foi constatado por $65 \%$ dos motoristas, os respondentes enfatizaram que esta questão atrasa as entregas. Segundo um dos motoristas, "há um shopping que sempre barra o meu ajudante, e eu acabo descarregando as mercadorias sozinho, o que demora o dobro do tempo, e o meu ajudante fica na rua sozinho me esperando". A Figura 11 mostra a quantidade de respostas para cada problema investigado.

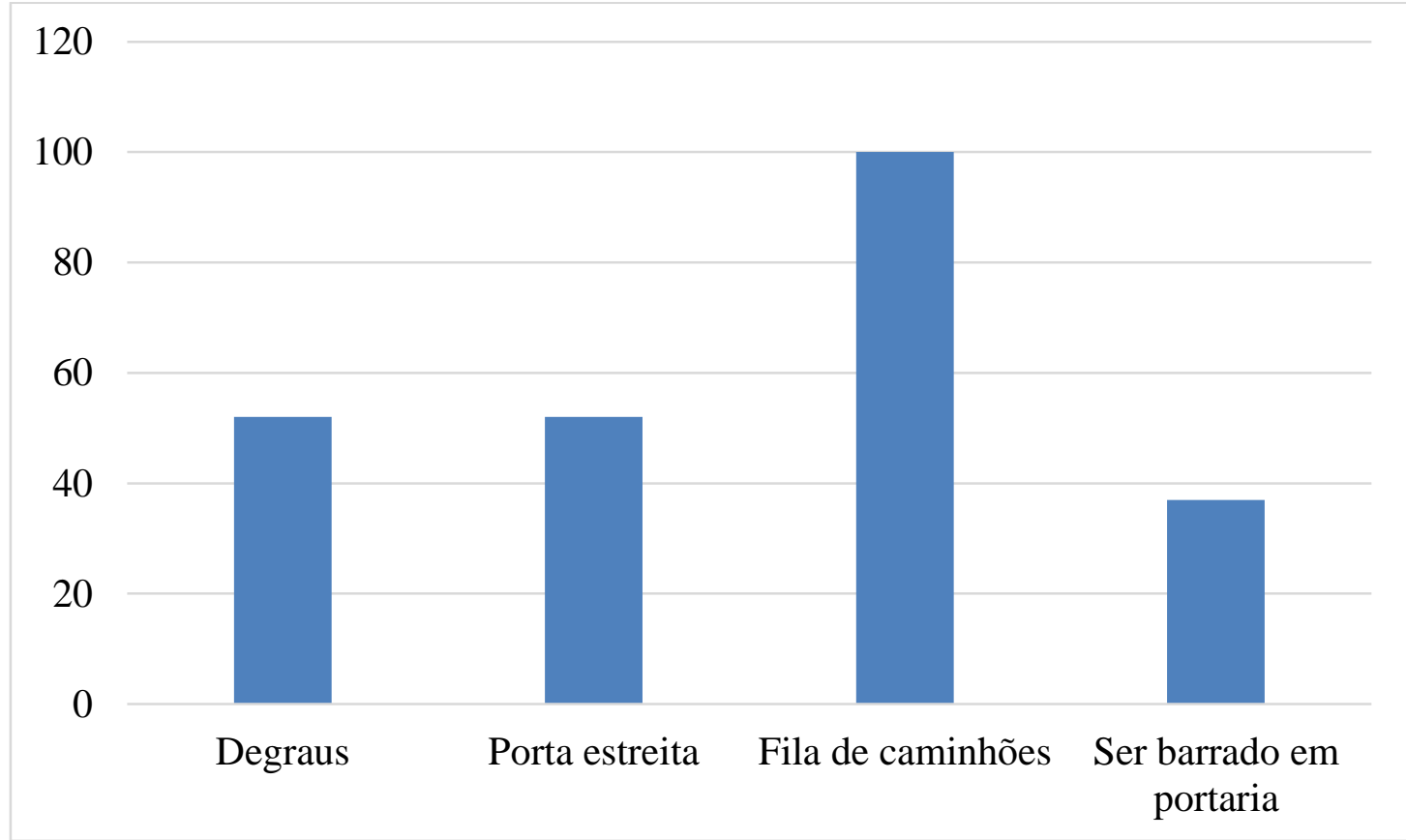

Figura 11 - Número de respostas para problemas de estrutura

Outro fator que faz a diferença para agilidade da descarga está relacionado às condições doca, se o estabelecimento possuir a doca elevada, a rampa do caminhão não precisa ser acionada, e assim não há necessidade de subir e descer essa rampa para descarregar os paletes. Outra vantagem da presença de docas elevadas é que o caminhão não precisará permanecer ligado durante o descarregamento para movimentar essa rampa, o que pode evitar problemas 
com ruído, e reduz também a emissão de poluentes. A presença de uma doca interna e o dimensionamento das mesmas pode contribuir para diminuir o tempo de descarregamento e melhorar a eficiência das entregas (ALMEIDA et al., 2009).

As respostas e os depoimentos dos motoristas corroboram que as condições da estrutura de recebimento das lojas contribuem para o desempenho logístico das entregas (PORTER et al., 2012). Além do desempenho logístico, a agilidade para descarregar mercadorias durante a noite é imprescindível para evitar assaltos, o que demonstra que muitas lojas precisam investir em estrutura de recebimento para efetuar as entregas noturnas com mais segurança.

\subsubsection{Identificação dos problemas para as entregas noturnas}

Dos 74 motoristas que responderam à pergunta sobre terem vivenciado ou não problemas com ruído, 55 (65\%) responderam positivamente, e alguns deles relataram que agressões, verbais ou físicas, por parte dos vizinhos é frequente. O principal motivo gerador de ruídos, segundo os motoristas, é o barulho do caminhão ligado. Posto isto, os mesmos sugerem as seguintes medidas preventivas: construção de docas elevadas e prioridade de descarregamento de perecíveis, pois estes necessitam de refrigeramento e este sistema refrigerador funciona apenas com o caminhão ligado. Outras sugestões dos motoristas para mitigar ruídos são: estacionar longe da vizinhança, puxar o freio de mão devagar, não falar alto e não bater a porta do caminhão. Além das ações dos motoristas, são diversos os fatores que podem gerar ruídos, e a busca de soluções para mitigar este problema pode contribuir para a execução das entregas noturnas e melhorar a eficiência das entregas urbanas (FINLAY, 2008).

Quanto às questões de segurança, $89 \%$ motoristas se mostraram preocupados com a execução do projeto, justamente pelo medo de assaltos, o que corrobora com os problemas do subdesenvolvimento citados por Costa (2015). Entre os locais mais perigosos citados pelos motoristas estão o centro de São Paulo e as rodovias do Estado de São Paulo, principalmente nas proximidades com a Marginal Tietê e Pinheiros, e também bairros da periferia. Mesmo com a sensação de insegurança, 70\% dos motoristas disseram preferir trabalhar a noite. 


\subsection{Análise descritiva dos dados dos recebedores}

\subsubsection{Perfil dos respondentes e da empresa}

Nesta pesquisa com os recebedores, foi considerada uma amostra de 84 respondentes de empresas que realizam ou já realizaram o abastecimento noturno no município de São Paulo. Houve uma grande variabilidade no cargo exercido pelos entrevistados: gerentes, subgerentes, chefes de loja, assistentes administrativos, chefe de operações, gerente distrital, gerente volante, operador pleno de FLV (Frutas, Legumes e Verduras) e supervisor. A Tabela 6 traz as medidas estatísticas para o tempo de profissão dos respondentes.

Tabela 6 - Medidas estatísticas para o tempo de trabalho do recebedor

\begin{tabular}{lr}
\hline \multicolumn{2}{c}{ Tempo de trabalho no cargo } \\
\hline Média & 6.31 \\
Mediana & 3.00 \\
Desvio padrão & 13.29 \\
\hline
\end{tabular}

A Tabela 6 mostra um tempo de trabalho relativamente médio, embora um desviopadrão alto. Porém, pela mediana, pode-se inferir que $50 \%$ dos encarregados por responder esta pesquisa possuem 3 anos de experiência no cargo, um tempo menor de profissão, se for comparado com o caso dos motoristas.

\subsubsection{Caracterização da organização da loja}

Nesta seção, as variáveis de análise serão: horário de maior movimentação de clientes na loja e melhor horário para alocar mercadorias nas gôndolas.

Uma das vantagens em realizar entregas noturnas é a agilidade em recerber, conferir e armazenar mercadorias (HOLGUIN-VERÁS et al., 2010), já que, em horários alternativos, há menos influência dos clientes nestas atividades. Com essa constatação, foi interrogado aos recebedores qual é o horário com maior movimentação de clientes e o melhor horário para alocar mercadorias nas gôndolas. Nesta pergunta, os respondentes puderam escolher de 1 a 3 períodos de preferências. O resultado pode ser visualizado na Figura 12. 


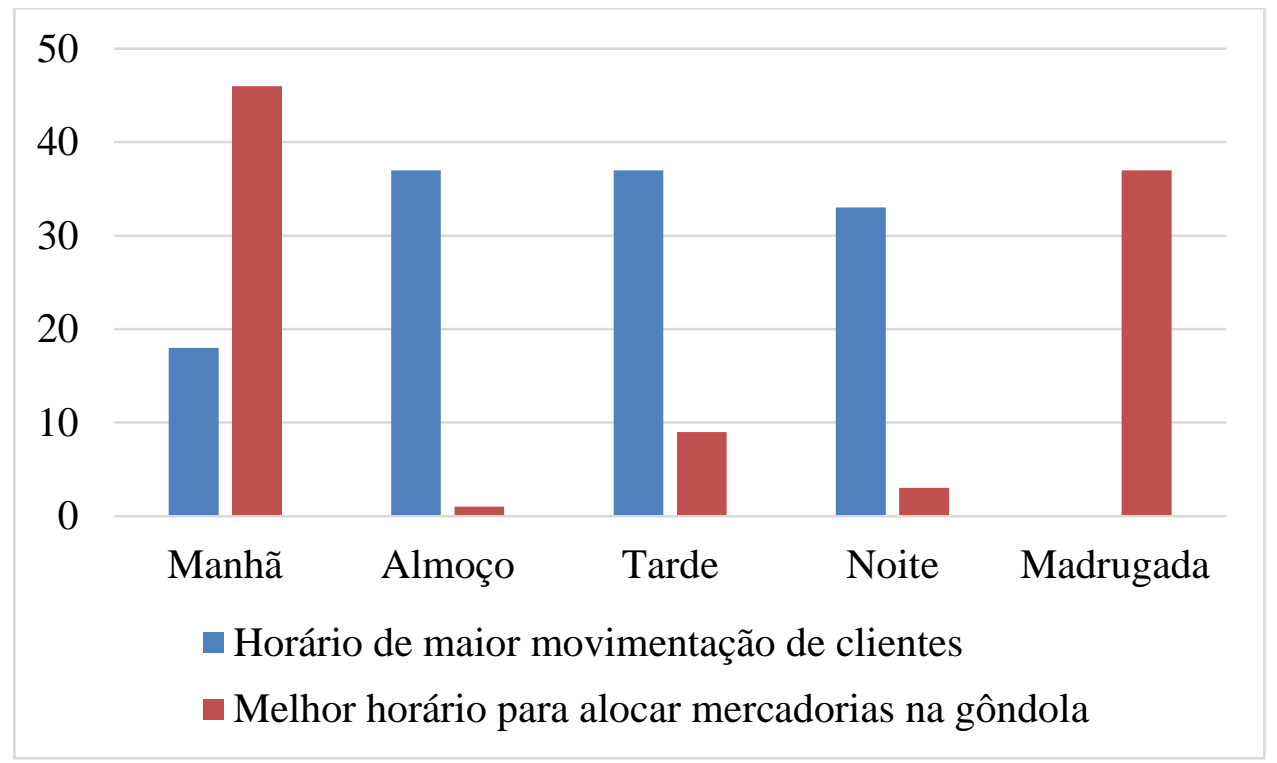

Figura 12 - Desempenho logístico dos varejistas

A Figura 12 mostra que há uma relação entre os horários com menor movimentação de clientes na loja (manhã e madrugada), com o melhor horário de alocar mercadorias na gôndola (manhã e madrugada), enquanto os horários com maior movimentação de clientes na loja (horário do almoço e tarde) não são sugeridos para alocar mercadorias na gôndola.

\subsubsection{Caracterização das ações do poder público}

Três estruturas foram selecionadas para análise: iluminação, demarcação de vagas de carga/descarga e calçadas.

A primeira estrutura investigada é a iluminação pública. A intenção em perguntar se há iluminação adequada no entorno da loja, é o de assinalar locais com propensão a assaltos. Dos 83 respondentes, apenas $26(31,3 \%)$ consideram a iluminação pública muito ruim ou ruim, conforme retrata a Figura 13. 


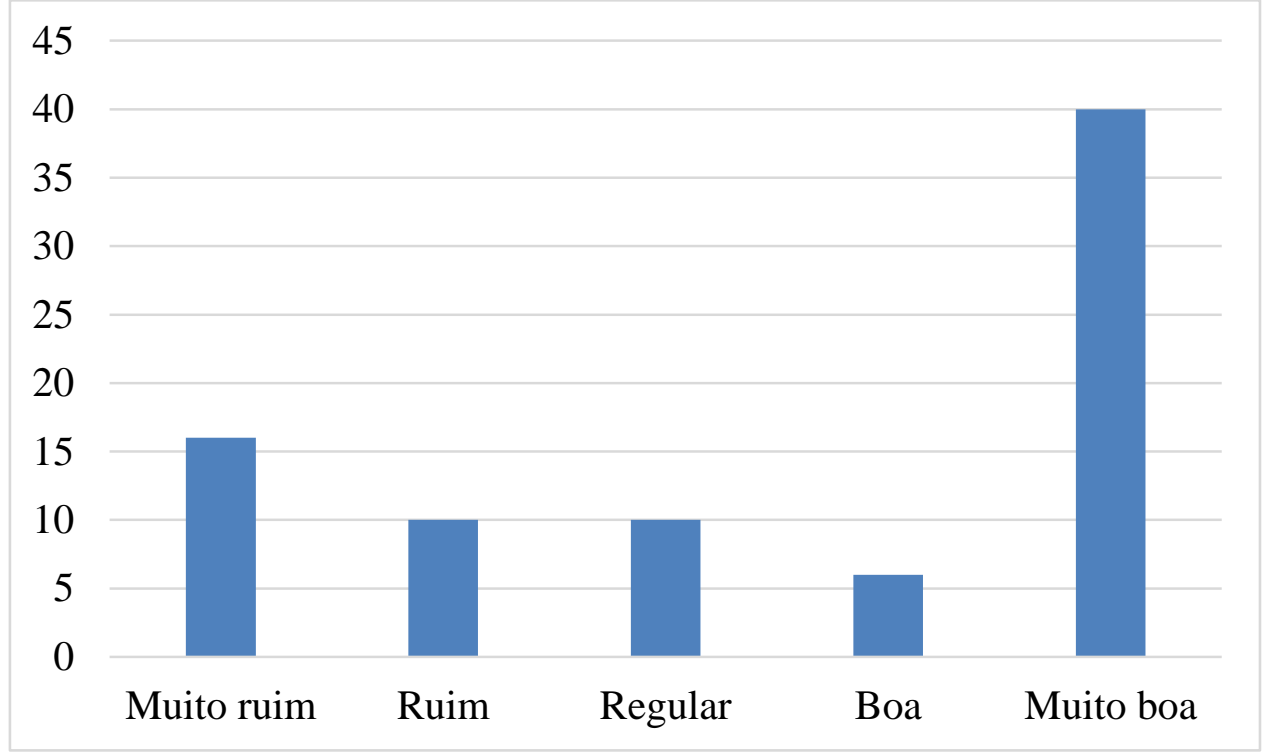

Figura 13 - Número de respostas para as condições de iluminação pública

Quanto à necessidade de demarcação de vagas de carga/descarga, dos 77 que responderam a esta indagação, $33(42,8 \%)$ disseram que essa ação é pouco importante, 2 $(0,02 \%)$ disseram que esta ação é importante e 42 (54,5\%) relataram que esta ação é muito importante para melhorar o descarregamento de mercadorias. Ou seja, $44(57,1 \%)$ respondentes gostariam que demarcasse vagas de carga/descarga nas proximidades, sendo que este número se aproxima dos 47 respondentes que não possuem doca interna no supermercado. Vale lembrar que em alguns casos a doca só possui capacidade para um caminhão, o que obriga os outros veículos de carga a estacionarem na rua, com a possibilidade de: não haver vagas, de estacionar em local proibido e tomar multa, e do maior risco com assaltos. A demarcação de vagas de carga/descarga gera mais rapidez no descarregamento, e menos emissão de poluentes, já que os veículos não precisam ficar rodando em busca de vagas para parar. Além disso, a escolha do local e geometria apropriados são essenciais para eficiência de entregas de carga urbana (OLIVEIRA, 2014).

Dos 80 entrevistados que responderam sobre calçadas, 44 (55\%) declararam ser pouco importante melhorar as calçadas, 7 (12,7\%) afirmaram ser importante e 49 (61,3\%) entendem que é muito importante o poder público melhorar as calçadas, tendo em vista que a existência de uma doca interna pode influenciar nesta resposta. Em muitos casos, o descarregamento de veículos é feito nas calçadas (ZAMBUZI, 2015), portanto a melhoria desta estrutura pode influenciar no tempo de descarregamento, o que poderia agilizar o roteiro de entregas, e contribui para melhorias na logística urbana (DABLANC, 2007). 
As respostas dos varejistas para este bloco de análise se assemelham às impressões dos motoristas, pois a iluminação pública é tida como o fator menos problemático. Quanto às calçadas e à necessidade de demarcar vagas de carga e descarga, a maioria dos varejistas declara que melhorias são imprescindíveis, pois a demarcação de vagas de carga e descarga pode agilizar o descarregamento e reduzir o trânsito nas proximidades da loja, e as calçadas melhoradas podem reduzir os acidentes com os funcionários das lojas e o risco de avarias, servindo também para melhorar a passagem dos clientes da loja.

\subsubsection{Caracterização da estrutura de recebimento}

Um dos aspectos de análise deste bloco sobre a estrutura de recebimento é qual o melhor jeito de efetuar as entregas noturnas: de forma assistida (com funcionários da loja) ou não-assistida (sem funcionários da loja). Dos 84 estabelecimentos estudados, 15 (17,8\%) destes, fizeram entregas não-assistidas. Destes 15, apenas 5 respondentes consideram as entregas não-assistidas mais eficientes do que as entregas assistidas, como mostra a Figura 14, que ainda mostra que a maioria dos que fizeram entregas assistidas preferem continuar a executar entregas assistidas, enquanto a maioria dos que fizeram entregas não-assistidas preferem realizar entregas assistidas.

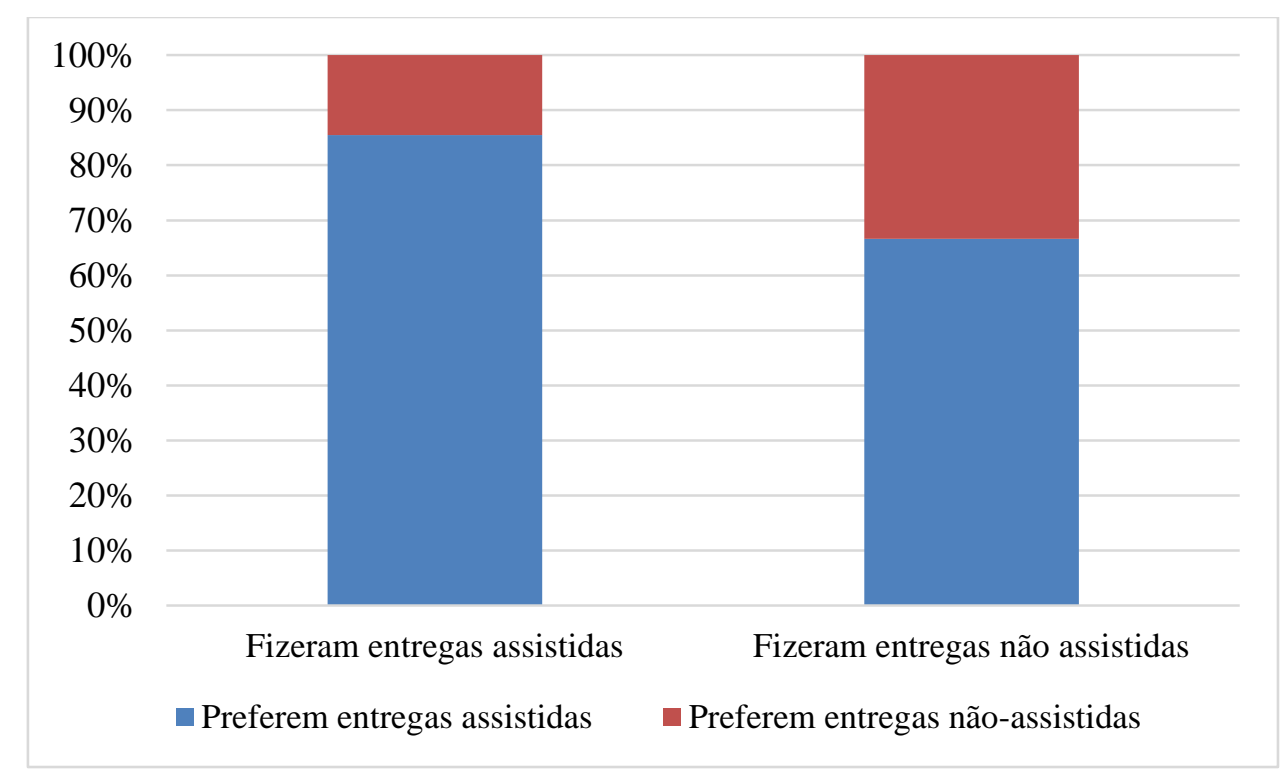

Figura 14 - Percentual da preferência do tipo de entrega 
Do total da amostra, apenas $18 \%$ consideram as entregas não-assistidas a melhor forma de receber mercadorias a noite. A preferência por entregas assistidas pode sugerir que há uma carência de confiança entre os sujeitos que compõe a cadeia de suprimentos.

Dois gerentes traçaram o perfil dos produtos recomendados para fazer entregas nãoassistidas: frutas, legumes e verduras. Estes produtos possuem baixo valor agregado, e a falta de uma ou poucas unidades é resolvida com a reposição destas por parte do fornecedor. São mercadorias bastante procuradas por donos de restaurantes, que exigem boas condições e frescor destas, por isso os chamados FLV são altamente recomendáveis para que sejam entregues no período noturno. Aproveita-se a oportunidade para refutar a tese de que as entregas não-assistidas necessitam de altos níveis de investimento em equipamentos de alarme e câmera (HOLGUÍN-VERAS et al., 2010), pois em duas lojas participantes do projeto, o motorista deixa as caixas de FLV em um local próximo a doca, sem a presença de alarmes ou câmeras, de forma que tanto fornecedor, quanto varejista, estão satisfeitos com os procedimentos. Um dos gerentes ressaltou a importância dos níveis de confiança entre fornecedor e varejista para efetuar as entregas não-assistidas.

Tendo em vista que a infra-estrutura do sistema logístico de uma empresa influencia em seus indicadores de desempenho (PORTER et al., 2010), foi perguntado aos recebedores quais estruturas dificultam o recebimento. $\mathrm{O}$ número de respostas para cada estrutura que atrapalha o recebimento pode ser visto na Figura 15.

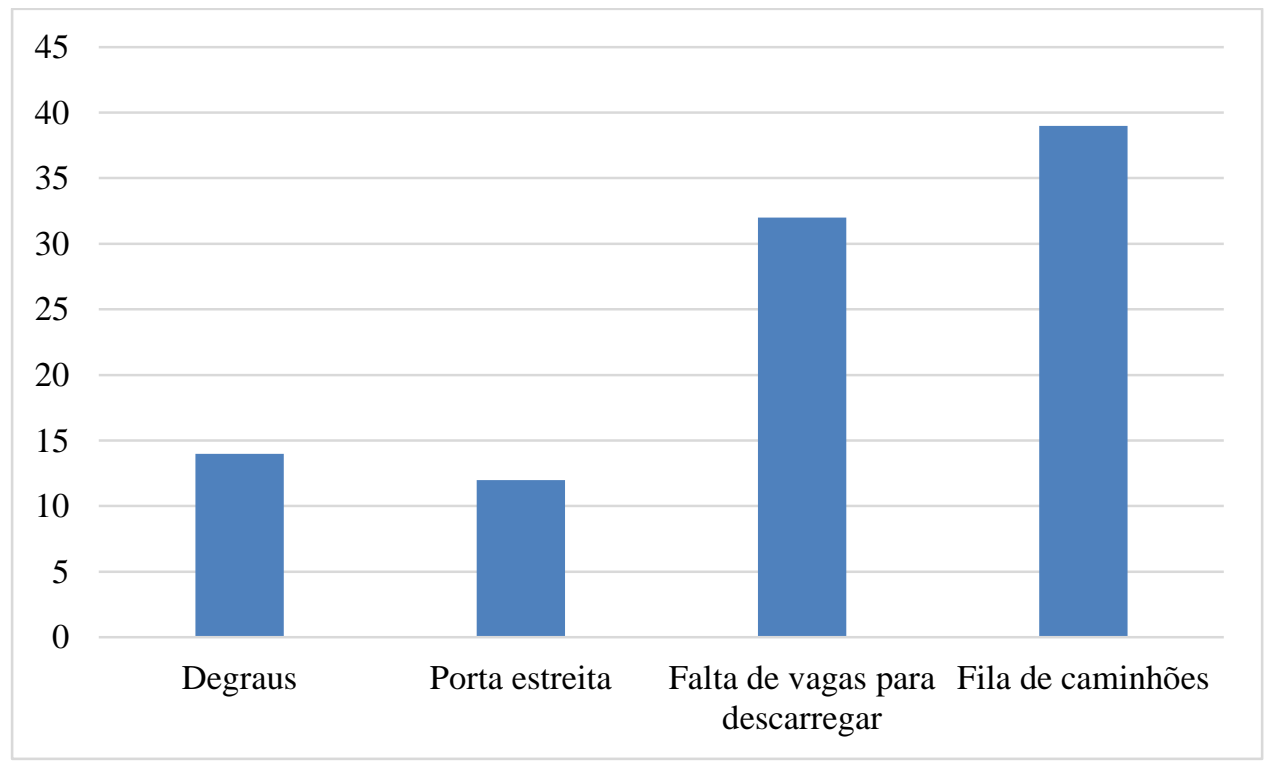

Figura 15 - Número de respostas para problemas de estrutura 
Assim como ocorrera com os motoristas, a fila de caminhões é o problema mais recorrente nas perações de descarregamento. Entretanto, quanto a presença de degraus e porta estreita houve uma divergência maior, pois mais de $90 \%$ dos motoristas respondentes relataram que entregam frequentemente em lojas com estes problemas, enquanto menos de $20 \%$ dos varejistas assumiram estes defeitos em suas dependências. As entregas noturnas podem diluir o fluxo de caminhões na doca, diminuindo o tempo de descarregamento e otimizando as entregas de carga no ambiente urbano (ANTP, 2015).

\subsubsection{Análise das entregas}

Para a análise da entrega, serão apresentados os dados referentes a quatro aspectos de análise: pontualidade, agilidade para conferir e armazenar, qualidade de atendimento ao cliente, nível de estresse do estoquista. As respostas estão sintetizadas na Figura 16, e em seguida são destrinchadas.

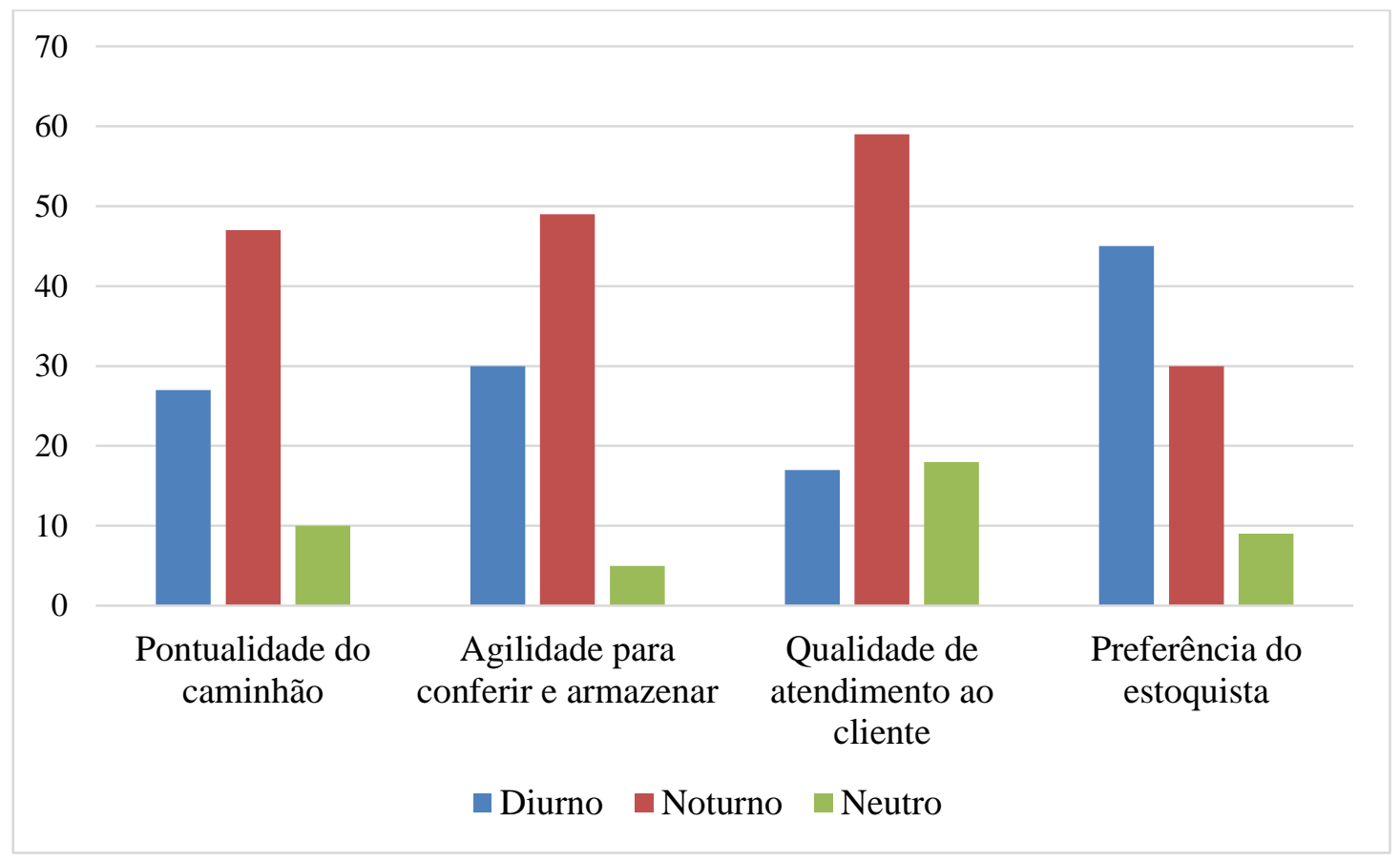

Figura 16 - Desempenho logístico da empresa

A previsibilidade da chegada dos caminhões, o que também foi constatado pelos motoristas, e na revisão bibliográfica, é mais confiável no período noturno. Para $63 \%$ dos respondentes, durante a noite os caminhões são mais pontuais, $27(32,1 \%)$ disseram que os 
caminhões no período diurno são mais pontuais e $10(11,9 \%)$ se mantiveram neutros nessa comparação. A resposta da maioria dos lojistas corrobora com Holguín-Veras et al. (2010) o qual afirma que os horários das entregas durante a noite são mais assertivos, influenciando na eficiência da logística urbana.

Para a gerente de uma loja entrevistada, essa previsibilidade facilita a venda de mercadorias por telefone, pois esta respondente relatou ter efetuado uma venda contando com a chegada dos produtos de um caminhão. Entretanto, o caminhão atrasou, a cliente foi à loja buscar sua compra, e o pedido estava incompleto, pois faltou o produto que não chegou à loja na janela de horas previamente marcada.

Quanto a agilidade para conferir e armazenar as mercadorias, lembrando que no período noturno não há clientes ou há menos clientes para transitar durante a organização das gôndolas, 49 (58,3\%) dos 84 entrevistados disseram que estas atividades são mais ágeis com o descarregamento feito no período noturno, $30(35,7 \%)$ disseram que há mais agilidade para conferir e armazenar mercadorias com o descarregamento sendo feito no período diurno e 5 $(5,9 \%)$ não responderam a esta questão. O alto número de respostas de que no período diurno as tarefas de armazenagem e conferência são mais ágeis se deve ao maior número de trabalhadores ajudando no descarregamento durante o dia. Em uma das lojas entrevistadas, foi dito que a falta de pessoal para executar a essas tarefas durante a noite, levou ao não recebimento das mercadorias, pois não haveria quantidade de funcionários suficiente para processar as mercadorias que seriam recebidas até a abertura da loja. Entretanto, o maior número de respostas para o período noturno corrobora com o estudo feito na rede de supermercados Mercadona (2010) de que as entregas noturnas facilitam a conferência e organização das lojas.

A qualidade de atendimento ao cliente pode ser melhorada com as entregas noturnas, pois as compras dos clientes não seriam atrapalhadas com a tarefa de organização das lojas (HOLGUÍN-VERAS et al., 2013). Para 59 (70,2\%) dos 84 respondentes, o descarregamento noturno eleva o nível de atendimento ao cliente, para $17(20,2 \%)$ respondentes o descarregamento diurno é mais favorável para a qualidade de atendimento ao cliente e 18 $(21,4 \%)$ não responderam esta questão. Duas lojas entrevistadas admitiram que já vivenciaram reclamações de clientes devido à presença de caixas e carrinhos espalhados para alocar mercadorias na gôndola. Em outra loja, o gerente relatou que os principais clientes do período matutino são idosos, os quais possuem mais riscos em se acidentar se não enxergarem 
as caixas ou produtos espalhados pelo chão, e também são os mais exigentes quanto ao nível de atendimento do supermercado.

$\mathrm{O}$ fator que pode prejudicar a eficiência na conferência e armazenagem das mercadorias é o maior nível de estresse sentido pelo estoquista entre as $21 \mathrm{~h}$ e $6 \mathrm{~h}$, pois $60 \%$ dos entrevistados que responderam a esta questão preferem trabalhar no período diurno, devido a motivos tais como: dificuldade em adequar o organismo a trabalhar a noite, falta da família e insegurança.

Vale lembrar que a vantagem em aumentar o tamanho do pedido, devido à utilização de caminhões maiores no período noturno (HOLGUÍN-VERAS et al., 2014; MERCADONA, 2010), não foi praticada. Todos os respondentes disseram que não foi modificada a política de estoque ao realizar entregas noturnas. Os respondentes alegaram que os pedidos são feitos automaticamente, com o auxílio de softwares, que calculam a diferença entre o que foi vendido e o que permanece no estoque, para calibrar o tamanho do pedido. Portanto, assim como foi visto com os motoristas, as empresas não estão modificando a política de estoques e transportes de modo a garantir mais eficiência às entregas noturnas, sendo que o aumento do tamanho do pedido pode diminuir a frequência de entregas otimizando a distribuição de cargas urbanas (DABLANC, 2007).

Apesar dos problemas, e da falta de conhecimento de práticas que melhoram a eficiência das entregas noturnas, as entrega noturnas são as preferidas de $65 \%$ dos respondentes em comparação com as entregas diurnas.

\subsubsection{Identificação dos problemas para as entregas noturnas}

A percepção dos recebedores corrobora que os problemas, quanto às entregas noturnas, são, predominantemente, os ruídos e os riscos relacionados ao roubo do estabelecimento e da carga.

Quanto à segurança, 58\% dos entrevistados declararam que não há segurança para receber cargas a noite. Um fator relevante para evitar assaltos provém do depoimento de uma respondente. A gerente de uma das lojas estudadas alertou para que os estabelecimentos receptores de cargas noturnas não mantivessem caixas eletrônicos no interior da loja. Vale ressaltar, que uma infra-estrutura adequada agiliza o recebimento de mercadorias, e esta agilidade é fundamental para evitar a ocorrência de delitos. 
Dos 84 estabelecimentos, $33(39,2 \%)$ relataram ter tido problemas de reclamação da vizinhança durante os descarregamentos noturnos. Alguns recebedores apontaram que mercadorias com o peso mais leve, como pão, bazar e FLV fazem menos barulho durante o descarregamento, desta maneira são tidos como mais adequados para o período noturno. De acordo com 2 gerentes entrevistados, o descarregamendo de mercadorias tipo mercearia pode ser feito até as 23 horas, pois após este horário há reclamações da vizinhança.

Além disso, colocar revestimento acústico nas docas, desligar as máquinas de prensar lixo, promover a manutenção dos portões e efetuar o descarregamento com mais rapidez pode ajudar a evitar problemas com a emissão de ruídos, de acordo com os respondentes. Os gerentes das lojas que tiveram problemas com ruído salientam a necessidade da comunicação entre empresa e vizinhança para resolver estes conflitos. Vale lembrar que os ruídos são os principais problemas para a realização de entregas noturnas (YANNIS et al., 2006), e mitigar este fator pode significar mais caminhões circulando no período noturno e diminuição do trânsito nos horários de pico (HOLGUÍN-VERAS et al. 2010).

\subsection{Análise de correspondência aplicada à percepação de entregas diurnas versus}

\section{noturnas}

Um dos resultados possibilitados pela análise de correspondência é um gráfico de normalização simétrica, com o objetivo de verificar como categorias de variável variam entre si. Os resultados obtidos a seguir possuem o método de normalização simétrico, ou seja, um mapa perceptual com as categorias das variáveis que diferenciam entregas noturnas e entregas diurnas. A análise de correspondência múltipla possibilita a redução da dimensão de diversas categorias de variável em uma escala ideal, de forma que possam ser colocadas em um gráfico com duas dimensões. A distância entre as categorias tem como ponto de partida as medidas de $\chi^{2}$, que refletem a associação entre estas categorias.

\subsubsection{Associação entre a preferência do horário de entrega e os problemas}

A análise de correspondência foi aplicada com o intuito de evidenciar os principais problemas oriundos da execução das entregas noturnas. As variáveis de análise referentes aos problemas das entregas noturnas são: ruídos, segurança pública, iluminação. Para cada uma 
dessas variáveis há duas categorias: com problemas de ruído (“Com_prob_ruído") ou sem problemas de ruído (“Sem_prob_ruído”); com problemas de segurança (“Com_prob_seg”) ou sem problemas de segurança (Sem_prob_seg); iluminação pública adequada ("ilumin_boa”) ou iluminação pública inadequada ("ilumin_ruim”).

Foram gerados escores que representam as distâncias físicas no mapa perceptual (Figura 17), de forma que quanto maior a distância entre as categorias das variáveis, menor a associação entre elas, e quanto menor a distância entre essas categorias, maior a associação entre as mesmas.

Foi utilizado mais especificamente o método de análise de correspondência múltipla, quando, nesta etapa o modelo foi aplicado duas vezes: com os resultados dos motoristas e com o resultado dos recebedores. Assim verficar-se-á quais categorias estão mais próximas da opção pelas entregas diurnas, e quais variáveis estão mais próximas da escolha pelas entregas noturnas para ambos sujeitos investigados, o que permite uma visão mais global desses problemas. Em cada uma das Figuras que representam esses modelos, as variáveis constam na legenda, e as categorias de cada variável estão com a mesma cor da variável da legenda. 


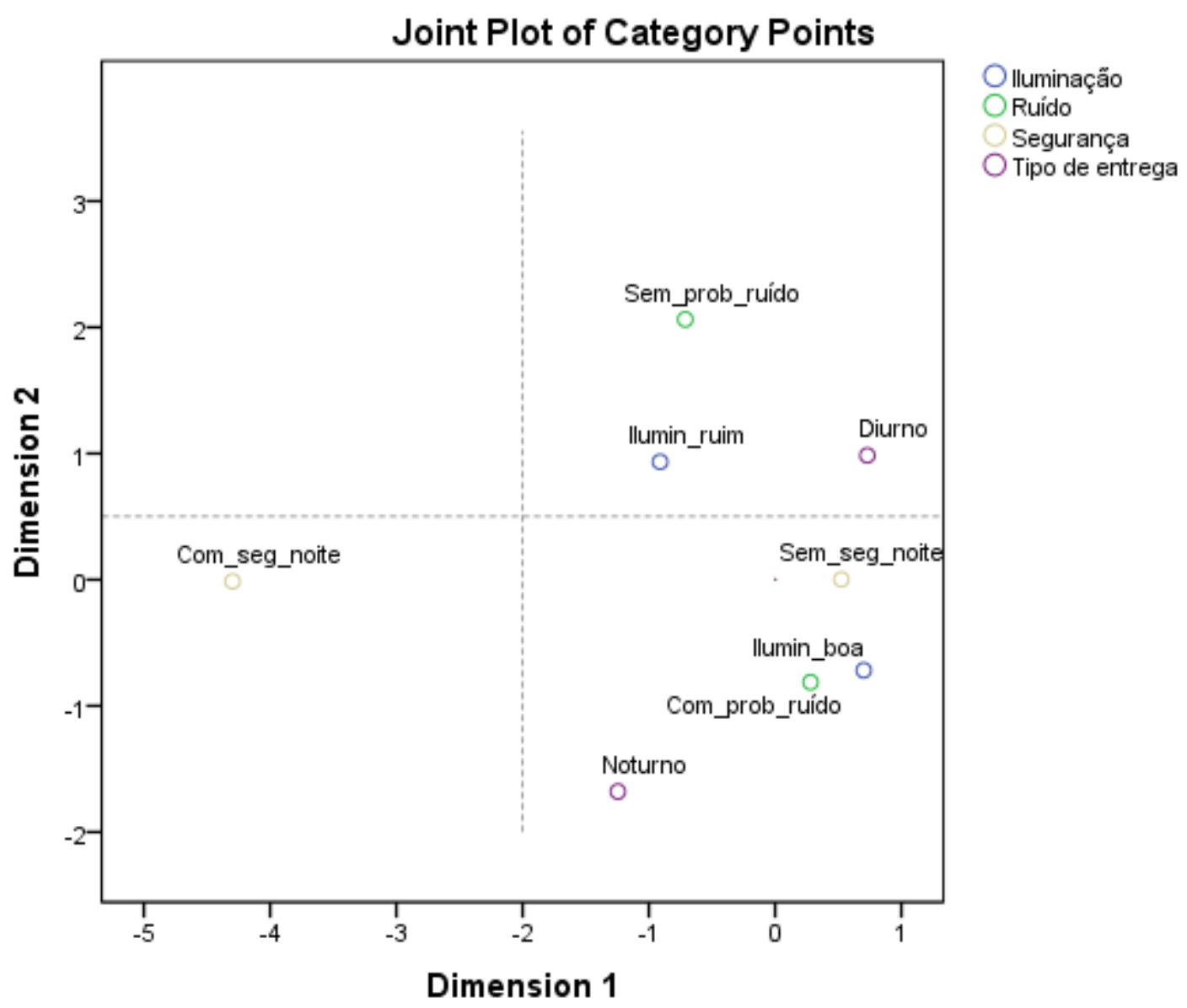

Symmetrical Normalization.

Figura 17 - Assosiação entre a preferência pelo horário de entrega e as categorias das variáveis que refletem os problemas, na opinião dos motoristas

A Figura 17 traz um gráfico, formado por duas dimensões, onde aparecem oito categorias de variáveis binárias: tipo de entrega (diurno e noturno), ruídos (não há problemas com ruído e há problemas com ruído), segurança (não há segurança a noite e há segurança noite), iluminação (condições inapropriadas de iluminação e condições apropriadas de iluminação). Quanto mais próximas estiverem uma das outras, maior associação entre estas categorias.

Para os motoristas, a entrega diurna está mais próxima de duas categorias de variável: sem segurança a noite ("Sem_seg_noite") e iluminação inadequada ("ilumin_ruim"). Ou seja, para os motoristas há a necessidade de criar condições para garantir que o descarregamento noturno ocorra com segurança. Vale ressaltar que a iluminação pública adequada é essencial para garantir os fluxos comerciais da metrópole (SANTOS, 2005). Nota-se também que a 
categoria "com segurança a noite" ("Com_seg_noite") aparece mais isolada pois apenas 10\% dos motoristas ententem que há condições seguras para realizar entregas urbanas no período noturno, enquanto as outras respostas tiveram respostas mais equilibradas. A partir das categorias de variáveis que se aproximam das entregas diurnas pode-se dizer que o principal problema para realizar as entregas noturnas é a segurança pública.

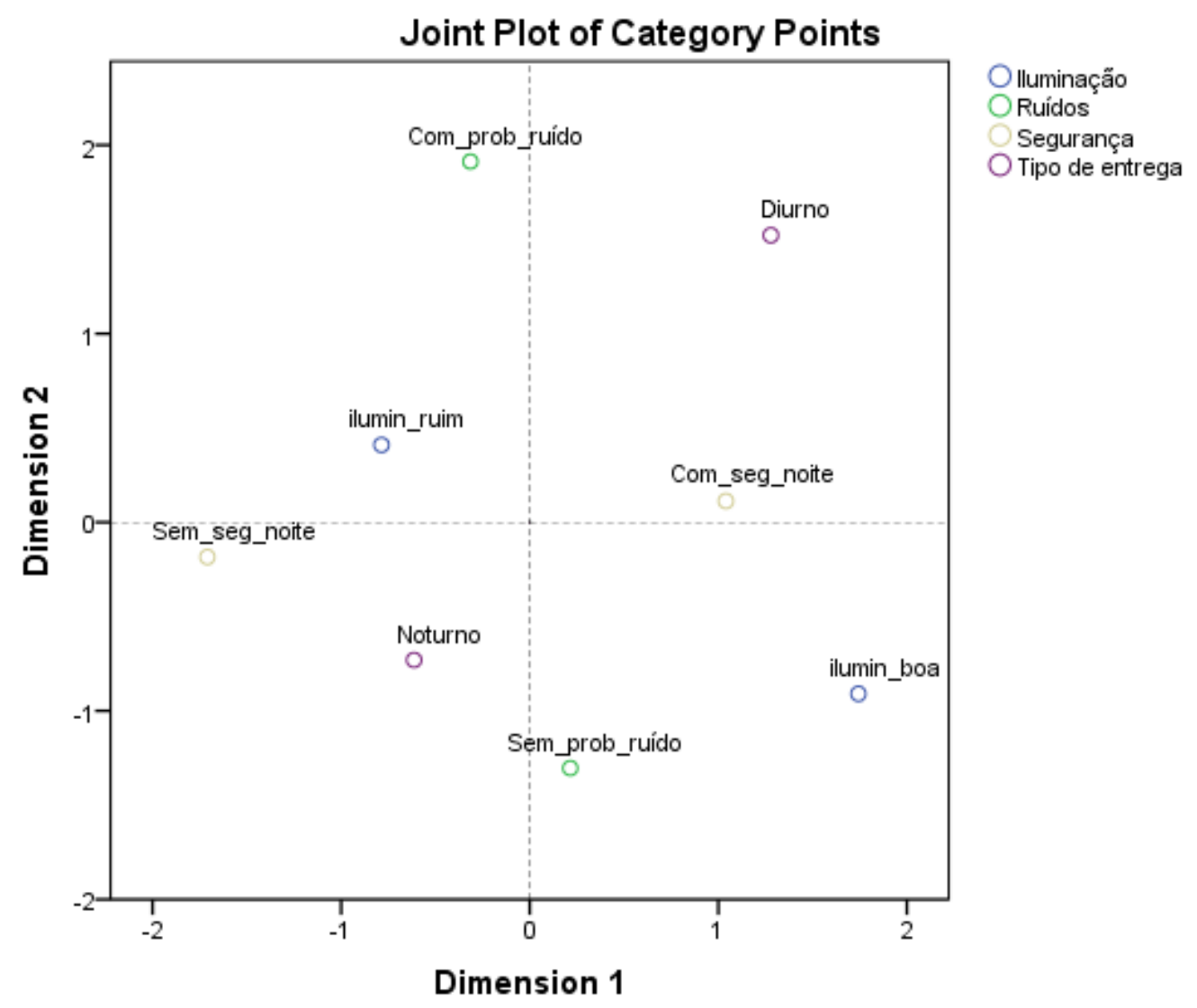

Symmetrical Normalization.

Figura 18 - Assosiação entre a preferência pelo horário de entrega e as categorias das variáveis que refletem os problemas, na opinião dos varejistas

Verifica-se na Figura 18 que as entregas noturnas estão próximas da categoria "Sem_prob_ruído" (sem problemas de ruído), enquanto as entregas diurnas estão próximas da categoria “Com_prob_ruído" (com problemas de ruído). Ou seja, são os ruídos que podem indicar a opção por fazer entregas urbanas no período diurno ou no período noturno. Vale lembrar que os ruídos podem ser o principal obstáculo para as entregas de carga durante a noite (YANNIS; GOLIAS; ANTONIOU, 2006). 


\subsubsection{Associação entre a preferência do horário de entrega e a eficiência logística}

Nesta etapa da pesquisa procura-se verificar quais variáveis mais contribuem mais melhorar a eficiência das entregas urbanas, tanto de dia quanto de noite. Para tanto, foram utilizadas as seguintes categorias: mais pontualidade durante o dia, mais pontualidade durante a noite, mais agilidade para conferir e armazenar durante o dia, mais agilidade para conferir e armazenar durante a noite, mais qualidade de atendimento ao cliente com recebimento diurno, mais qualidade de atendimento ao cliente com recebimento noturno, há vagas para estacionar, não há vagas para estacionar, há fila de caminhões, não há filla de caminhões.

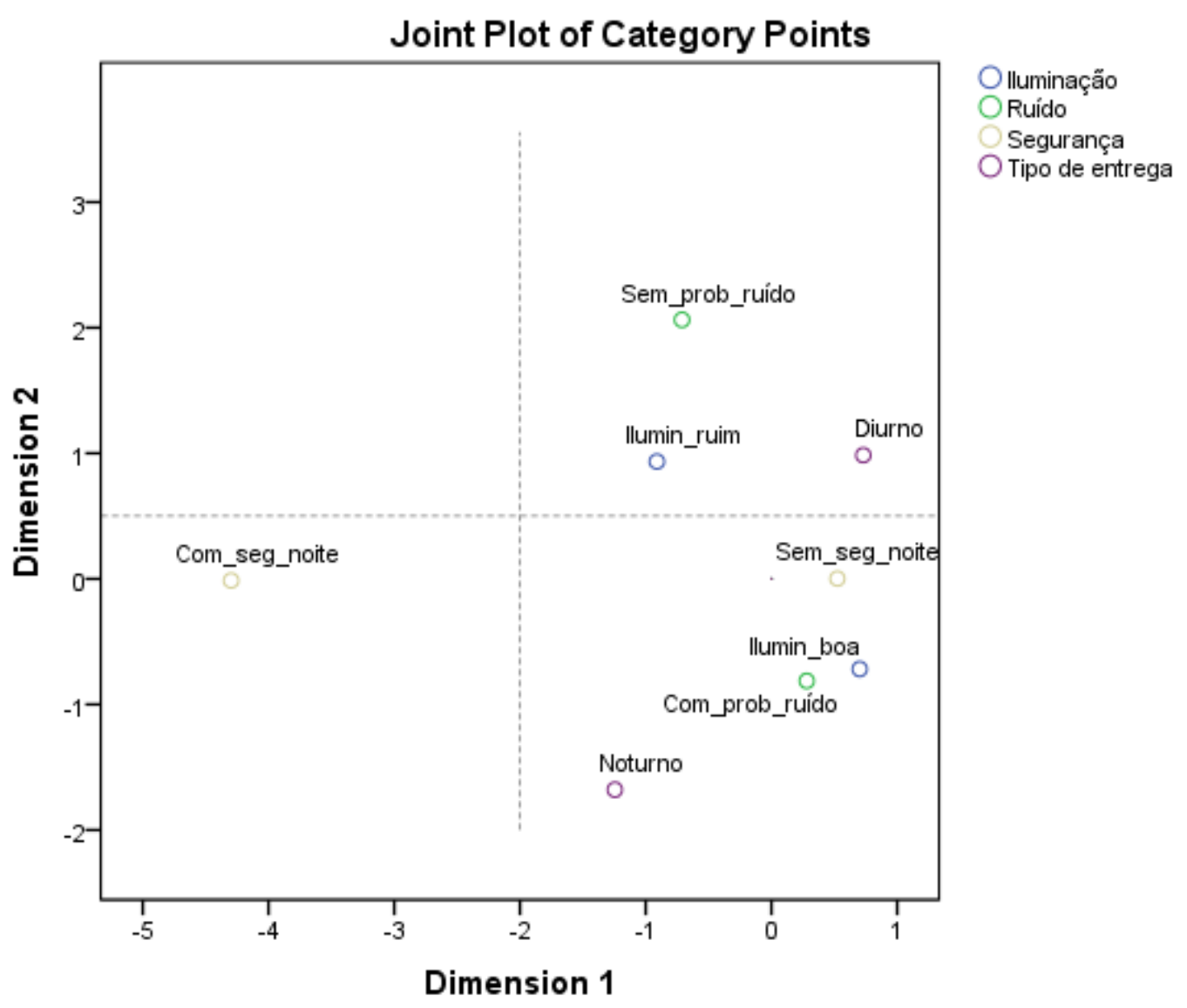

Symmetrical Normalization.

Figura 19 - Relação entre a preferência pelo horário de entrega e as categorias que refletem a eficiência logística, na opinião dos varejistas 
Através da Figura 19, verifica-se uma associação entre a preferência pelas entregas diurnas com três categorias de variáveis: mais agilidade para conferir e armazenar mercadorias durante o dia ("Mais_agi_dia"), mais qualidade de atendimento ao cliente com recebimento diurno ("Mais_quali_dia") e pontualidade mais assertiva durante o dia ("Mais_pont_dia"). Neste momento, vale lembrar que parte dos entrevistados se queixou da falta de pessoas para formar uma equipe noturna, principalmente da dificuldade em encontrar um líder experiente para trabalhar no período noturno. Segundo um entrevistado (gerente de loja), relatou "uma remessa de mercadorias chegou a voltar ao centro de distribuição pela falta de pessoas para conferir e armazenar as mercadorias antes da abertura da loja”. Ou seja, a presença de uma equipe formada e devidamente orientada por um líder experiente no período diurno pode ter feito com que os entrevistados respondessem que durante o dia é mais ágil para conferir e armazenar mercadorias.

Para os recebedores que preferem realizar as entregas noturnas, aparecem três categorias mais próximas: mais qualidade de atendimento ao cliente com recebimento noturno ("Mais_quali_noite"), agilidade em conferir e armazenar durante a noite ("Mais_agi_noite"), pontualidade mais assertiva durante a noite ("Mais_pont_noite). O posicionamento mais próximo destas categorias reforça a associação entre as mesmas, de forma que a realização de entregas noturnas pode melhorar a qualidade de atendimento ao cliente, devido à maior assertividade quanto ao horário de chegada do caminhão e à maior agilidade em conferir e armazenar mercadorias. A agilidade em conferir e armazenar mercadorias no período noturno pode ser melhor pois as lojas se encontram vazias, e os funcionários possuem mais espaço para as caixas e mais tranquilidade para armazenar as mercadorias na gôndola.

Outra constatação interessante é a de que a principal vantagem em realizar as entregas noturnas não está associada às condições de descarregamento (fila de caminhões e vagas para estacionar), mas sim à organização interna da loja, desde a maior certeza quanto ao horário de chegada do caminhão até a agilidade de conferir e armazenar.

\subsection{Análise comparativa entre o programa de entregas noturnas de São Paulo com} os outros programas de entregas noturnas em outras cidades do mundo

A comparação entre as percepções sobre as entregas noturnas feitas para o município de São Paulo e as entregas noturnas executadas em outros locais do mundo foi feita de acordo 
com as subdivisões da seção 2.2 da revisão bibliográfica. Ou seja, primeiramente é abordado a respeito das motivações para a implementação de um programa de entregas noturnas; em seguida são destacados os principais stakeholders para o caso de São Paulo, e se estes se assemelham aos stakeholders dos outros projetos; logo após relaciona-se se os resultados positivos do caso de São Paulo com os resultados positivos alcançados em outros países; e finalmente, é feita a comparação entre os problemas decorrentes da realização dos descarregamentos noturnos identificadas em outras cidades, com os problemas explicitados pelos varejistas e motoristas de São Paulo.

\subsubsection{Motivações para a implantação de um programa de entregas noturnas}

As principais motivações para a implementação de um programa de entregas noturnas como política pública para o planejamento de transportes do município de São Paulo se assemelham às descritas por Stathopoulos et al. (2011) ao caracterizar Roma e Turim como cidades congestionadas, principalmente nas áreas centrais, e com grandes dificuldades de encontrar uma vaga para descarregar. Zambuzi (2015) aborda as dificuldades para a questão de encontrar uma vaga para efetuar o descarregamento de mercadorias no município de São Paulo. Tais justificativas também podem ser vistas em Holguín-Verás et al. (2010) ao abordar o caso de Nova York. Cunha e Yoshizaki (2014) relacionam o dinamismo econômico da Zona Máxima de Restrição de Circulação (ZMRC) com o nível de congestionamento, e a necessidade de buscar soluções eficientes para o transporte de carga em regiões com alta atividade econômica.

As entregas noturnas também podem ser vistas como uma política empresarial do setor logístico, visando melhorar alguns indicadores da empresa como tempo de rota (Holguín-Verás et al., 2014), tempo de descarregamento (ANTP, 2015), tempo para conferir e armazernar mercadorias (HOLGUÍN-VERÁS et al., 2010), pontualidade (PIER PASS, 2015) além de reduzir os conflitos entre clientes e motoristas na busca por uma vaga para estacionar os veículos (VASCONCELOS, 2005). Através dos resultados da survey realizada com motoristas, foi assinalado pelos motoristas que o tempo médio de rota no período noturno é consideravelmente menor do que no período diurno, assim como foi visto no projeto de Nova York (Holguín-Verás et al., 2014), e que no período diurno demora-se, em média, 35 minutos a mais para encontrar uma vaga para efetuar o descarregamento, sendo que Stathopoulos et al., (2011) também apontou um alto tempo para descarregar mercadorias em Turim e Roma. 
Nos projetos de Paris (DIZAIN 2012), Londres (DOUGLAS et al., 2008), Nova York (HOLGUÍN-VERÁS et al., 2010), houveram incentivos fiscais e monetários para a adesão ao programa governamental de entregas noturnas, o que não foi colocado no projeto piloto de entregas noturnas do município de São Paulo (ANTP, 2015).

\subsubsection{Stakeholders e o seu papel nas entregas noturnas}

O stakeholder responsável por iniciar a realização de reuniões com o intutito de fomentar um programa de entregas noturnas foi o órgão que normatiza o trânsito das cidades. No município de São Paulo, foi a CET (Companhia de Engenharia de Tráfego), em conjunto com o DSV (Departamento Superior Viário), foram os responsáveis por organizar e estimular a realização das entregas de carga no período noturno (ANTP, 2015).

Outro fato notável foi a participação de grandes empresas, líderes de mercado, no programa de entregas noturnas do município de São Paulo, que contribuíram para o convencimento para que outras empresas menores aderissem a tal programa. Vale lembrar, que os projetos de entregas noturnas de Barceloca (MERCADONA, 2010) e Nova York (HOLGUÍNVERÁS et al., 2010) também tiveram a participação essencial de grandes empresas na condução de seus projetos. Já em Paris (DIZAIN, 2012), Roma (STHATOPOULO et al., 2011), e Londres (DOUGLAS et al., 2008), primeiramente houve a seleção de locais de recomendados para a execução de entregas noturnas, e depois foi enviado o convite de participação do programa de entregas noturnas, não sendo a participação de grandes empresas preponderante para a realização de entregas noturnas nestas cidades.

A universidade desempenha uma função fundamental para o desenvolvimento de medidas eficientes para o transporte de carga. A neutralidade das pesquisas acadêmicas pode ser um fator favorável para a convergência de interesses do setor público e do setor privado (CAMBRIDGE SYSTEMATICS, 2009). Nos diversos projetos de entregas noturnas do mundo, as universidades tiveram sua participação, principalmente no monitoramento dos resultados e buscando soluções para otimizar a eficiência do transporte de carga (DOUGLAS et al., 2008).

\subsubsection{Resultados dos projetos pioneiros de entregas noturnas}

Os resultados dos projetos piorneiros de entregas noturnas pelo mundo entusiasmaram 
diversas autoridades e empresários (HOLGUÍN-VERAS et al., 2014).

As entregas noturnas podem ser feitas basicamente de duas maneiras: com funcionário interno da loja recebedora ou sem o funcionário interno da loja recebedora. No projeto de Nova York foi demonstrado que as entregas não-assistidas são mais eficientes, pois reduzem o consumo de energia elétrica por não haver o turno da madrugada, e também porque reduz o gasto com funcionários (HOLGUÍN-VERAS et al., 2010). Em Londres, a possibilidade de realizar entregas não-assistidas foi levantada devido às dificuldades em encontrar funcionários dispostos a trabalhar no período da madrugada (DOUGLAS et al., 2008).

A maioria dos motoristas e dos varejistas entrevistados no município de São Paulo rejeita esse tipo de recebimento, os quais alegaram a falta de confiança entre os sujeitos como principal motivo que inviabiliza as entregas noturnas não-assistidas. Além disso, deve-se ressaltar que $62 \%$ dos varejistas entrevistados entendem que é mais ágil para conferir e alocar as mercadorias no período da madrugada, e muitos deles afirmaram que esta é principal vantagem em realizar as entregas noturnas, ter as mercadorias conferidas, alocadas e organizadas antes da abertura da loja. Nos programas de Nova York (HOLGUÍN-VERAS et al., 2010) e de Londres (DOUGLAS et al., 2008), a agilidade em conferir e alocar as mercadorias no período noturno também foi vista como um dos aspectos mais favoráveis ao optar pelos descarregamentos noturnos, na opinião dos varejistas. Vale lembrar que os varejistas de São Paulo responderam que os melhores horários para alocar as mercadorias na gôndola não são durante o horário de pico.

Outra utilidade decorrente desta maior agilidade em conferir e alocar mercadorias no período noturno é o aumento da qualidade no nível do atendimento ao cliente, já que os consumidores das lojas não vão se deparar com as caixas, embalagens, paletes durante suas compras, além de encontrarem a loja arrumada e os produtos devidamente alocados. Destaca-se que alguns gerentes entrevistados disseram que produtos perecíveis entregues de madrugada chegam com maior frescor ao cliente, atendendo a expectativa de clientes que são donos de lanchonetes e restaurantes. A influência positiva das entregas noturnas na melhora no nível de atendimento ao cliente também foi constatada em Londres (DOUGLAS et al., 2008) e Nova York (HOLGUÍN-VERAS et al., 2010).

Quanto à pontualidade, $71 \%$ dos motoristas e $63 \%$ dos varejistas entrevistados no município de São Paulo afirmaram que as entregas noturnas oferecem mais assertividade quanto ao horário de chegada dos caminhões nos pontos de comércio, o que melhora a eficiência do ramo logístico da cadeia de suprimentos como um todo, como foi enfatizado pelo Pier Pass 
Program (2015), no projeto de entregas noturnas da Califórnia.

Foi visto no projeto de Roma (STHATOPOULOS et al., 2011) e de Nova York (HOLGUÍN-VERAS et al., 2010), que as entregas noturnas reduzem os custos logísticos, devido, entre outros fatores, a redução da quantidade de multas, decorrentes da restrição de circulação de grandes caminhões em certas regiões da cidade, devido ao rodízio de veículos nos horários comerciais, ou então por causa do estacionamento em locais proibidos. As multas por rodízio ou por restrição são eliminadas se as entregas urbanas forem realizadas no período noturno, e as multas por estacionamento praticamente são eliminadas também, a exceção ocorre quando a loja se localiza nas proximidades de bares e restaurantes em regiões cuja vida noturna é ativa.

Os resultados dos motoristas trouxeram uma grande discrepância entre o tempo estimado para encontrar uma vaga para estacionar no período diurno e o tempo estimado para encontrar uma vaga no período noturno, sendo que este foi um dos fatores que os motoristas de Nova York entendem que mais melhora se as entregas de carga urbana forem realizadas no período noturno (HOLGUÍN-VERAS et al., 2010). Devido à falta de vagas para estacionar, todos os motoristas entrevistados gostariam que houvesse mais vagas destinadas à função de carga/descarga. Adicionalmente, Holguín-Verás et al. (2010) constataram ganhos significativos nos custos logísticos totais, diante da eliminação das multas por estacionamento em local proibido.

O tempo de rota também sofre grande impacto, pois no período noturno as vias não estão congestionadas (CET, 2014). Os motoristas entrevistados no município de São Paulo relataram que demoram menos que a metade do tempo diurno para cumprir o mesmo romaneio no período noturno. No projeto de Nova York, foi calculado através da análise de dados de GPS que o tempo de rota no período noturno teria uma redução média de 1h30min (HOLGUÍN-VERAS et al., 2010). A análise de dados de GPS do projeto do município de São Paulo apontou uma diferença de aproximadamente $2 \mathrm{~h} 30 \mathrm{~min}$ a mais, no tempo de rota, no período diurno em relação ao período noturno (ANTP, 2015).

De forma geral, as percepções de motoristas e varejistas do município de São Paulo corroboram com a descrição dos resultados positivos dos diversos projetos de entregas noturnas pelo mundo, com destaque para a melhora na qualidade de atendimento ao cliente, decorrente da pontualidade dos caminhões e da eficiência em conferir e alocar mercadorias por parte dos varejistas; por parte dos motoristas, destaca-se a maior facilidade para encontrar uma vaga para descarregar e o tempo de rota. 


\subsubsection{Problemas para as entregas noturnas}

A realização das entregas noturnas pode acarretar em certas externalidades, como a emissão de ruídos (AINGE et al. 2014), a sensação de insegurança (HOLGUÍN-VERAS et al., 2010), a falta de pessoas dispostas a trabalhar no período noturno (DOUGLAS et al., 2008).

A emissão de ruídos é uma externalidade ressaltada nos projetos de entregas noturnas de Londres (AINGE et al., 2014), Barcelona (MERCADONA, 2010), Nova York (HOLGUÍNVERAS, 2014) e Vancouver (ONTARIO, 2013). No município de São Paulo, o questionário aplicado aos motoristas e varejistas que fizeram ou fazem entregas noturnas também assinalou a ocorrência de problemas com os ruídos emitidos durante o descarregamento no período noturno, pois $40 \%$ dos varejistas e $65 \%$ dos motoristas declararam que já estiveram presentes em conflitos com a vizinhança devido aos ruídos.

Diversas formas para a redução de ruídos foram testadas nos projetos de entregas noturnas de outros países. Por exemplo, em Nova York, foram testados paleteiras com a roda emborrachada, caminhões movidos a energia elétrica, rampas do caminhão com material de absorção de ruído, revestimento acústico em docas (HOLGUÍN-VERAS; HODGE, 2013). No projeto de Londres, verificou-se o estudo de outros aspectos mitigadores de ruído, como a implementação de asfalto com absorção de ruído, o estudo de rotas mais aptas para a circulação de veículos no período noturno, sistema de limitação de velocidades e treinamento com funcionários (AINGE et al., 2014). A rede Mercadona, que iniciou as entregas noturnas no município de Barcelona, estimulou a adaptação dos veículos de carga às entregas notunas, treinou seus funcionários para evitar conflitos com a vizinhança e testou o gás natural veicular como um combustível que reduz os decibéis oriundos do barulho do motor (MERCADONA, 2010). Em Vancouver, a lei foi readaptada, com o aumento do limite dos decibéis permitidos para que as entregas noturnas ocorram dentro da legalidade (ONTARIO, 2013). Já no município de São Paulo, as ações mitigadoras de ruído foram limitadas a um manual com boas práticas visando a mudança de comportamento dos funcionários e os informando como funciona a lei do PSIU no município de São Paulo (ANTP, 2015).

Como ocorrera em Vancouver, São Paulo também precisará adequar a lei de ruídos, se persistir em um programa de entregas noturnas como política de transportes para o planejamento urbano, pois a análise dos ruídos das entregas de carga noturna, traz o limite de ruídos ultrapassados, durante a manobra dos caminhões ou durante a passagem da paleteira pelo chão 
do caminhão (ANTP, 2015).

A análise de correspondência associou os ruídos com os varejistas que preferem realizar entregas noturnas, ou seja, os respondentes que preferem este tipo de entrega estão focados em reduzir os ruídos, de modo a viabilizar a continuidade das entregas fora do horário de pico.

Outro problema citado no projeto de entregas noturnas londrino é a falta de pessoas dispostas a trabalhar no período noturno (DOUGLAS et al., 2008). Quanto aos motoristas, embora parte deles se sintam mais estressados trabalhando no período diurno, eles optam por continuar trabalhando no período diurno, devido à dificuldade de adaptação do organismo ao trabalho noturno ou ao distanciamento da rotina familiar. Quanto aos trabalhadores noturnos do varejo, verificou-se que $60 \%$ destes preferem trabalhar de dia. Com base na revisão bibliográfica e nos resultados adquiridos no tratamento de dados, a dificuldade de adaptação do organismo humano ao trabalho durante a noite pode ser considerada uma dificuldade em realizar as entregas urbanas no período noturno.

O projeto de entregas noturnas de Nova York foi o único que levantou a possibilidade de haver mais vulnerabilidade de assaltos, principalmente entre as 3:00 e as 6:00 da manhã (HOLGUÍN-VERAS et al., 2010). As respostas obtidas na pesquisa empírica desta dissertação demonstram que a externalidade mais preocupante para os motoristas e varejistas é a segurança pública no período noturno, já que $89 \%$ dos motoristas e $58 \%$ dos varejistas se sentem inseguros ao trabalhares no período noturno. O mapa perceptual gerado a partir da análise de correspondência revela que a variável mais próxima da preferência em executar as entregas diurnas é a segurança pública, tanto na análise referente aos motoristas quanto na análise referente aos varejistas. 


\section{Considerações Finais}

As entregas noturnas passaram a fazer parte de políticas de planejamento urbano voltadas para o transporte de carga, pois estas contribuem para a redução do congestionamento de veículos, e reduzem a chance de acidentes entre caminhões e ônibus, ciclistas, pedestres e carros. Muitos projetos demonstaram que as entregas noturnas podem diminuir a poluição do ar, pois os veículos de carga ao permanecerem menos tempo trânsito emitem menos poluentes. Ou seja, as entregas noturnas podem melhorar a qualidade de vida dos cidadãos e contribuir para a busca de uma cidade sustentável, e para uma maior eficiência das empresas responsáveis pela entrega e recebimento de mercadorias.

O meio urbano do município de São Paulo é carcterizado por regulamentações que restringem a entrada de grandes caminhões nas regiões centrais, economicamente mais ativas, durante o período diurno. Há, também, proibições de grandes e pequenos caminhões nas vias classificadas como Vias Estruturais Restritas. O rodízio de veículos é outra norma que dificulta a circulação de caminhões nas áreas centrais. A infração dessas regulamentações gera multas para empresas transportadoras e fornecedoras, principalmente quanto à restrição de circulação e uma provável falta de vagas. A falta de vagas pode ser notada pelo elavado número de multas ocorridas por estacionar veículos em locais proibidos.

Os objetivos propostos nesta dissertação envolvem: investigar a diferença entre entregas noturnas e diurnas ao analisar a eficiência logística operacional decorrente da adesão às entregas noturnas por parte das empresas; verificar quais são os principais problemas atrelados às entregas noturnas.

A comparação das entregas diurnas com as entregas noturnas permitiu assinalar que, do ponto de vista dos motoristas, a redução do tempo de procura por uma vaga para descarregar nas regiões centrais parece ser uma mudança mais significativa se as entregas urbanas forem executadas no período noturno, e este fator pode reduzir o tempo de rota e melhorar a pontualidade dos caminhões. Além disso, as entregas noturnas podem diluir a quantidade de caminhões esperando para o descarregamento, o que diminui o tempo de espera e o tempo total de rota. Estas vantagens parecem superar a sensação de insegurança e os problemas com ruídos, pois a maioria dos motoristas preferem as entregas noturnas.

Sob a ótica dos recebedores, a possibilidade de elevar a qualidade de atendimento ao cliente é o fator mais atraente para executar as entregas noturnas. A maior certeza quanto ao 
horário de chegada do caminhão permite que as entregas sejam mais controláveis, e a ausência de clientes e outros percalços rotineiros oferece mais agilidade aos funcionários que conferem e armazenam mercadorias. Estes aspectos contribuem para a qualidade de atendimento ao cliente, e tornam a preferência dos recebedores, marjoritariamente, pelas entregas noturnas, apesar de preocupações com a falta de segurança e com a possibilidade de conflitos entre os stakeholders devido à emissão de ruídos.

As entregas noturnas do município de São Paulo devem ser feitas preferencialmente de maneira assistida, com a formação de uma equipe produtiva na madrugada, sendo imprescindível a presença de um líder ou de um funcionário experiente. Os produtos mais adequados para serem entregues de madrugada são de bazar, FLV e pães, pois possuem baixo valor agregado e o descarregamento ocorre de maneira mais silenciosa, já que são produtos mais leves. O descarregamento de produtos tipo mercearia pode ocorrer no período considerado noturno (21h-05h), desde que não exceda as 23 horas, horário a partir do qual os conflitos com a vizinhança são mais recorrentes. Se as entregas noturnas forem feitas por empresas fornecedoras de mercadorias, ou seja, se o dono da mercadoria não for o varejo, aspectos como colaboração e compartilhamento de informações tornam-se preponderantes.

Como trabalhos futuros, uma política adequada para entregas noturnas no município de São Paulo pressupõe a tomada de medidas efetivas para a mitigação dos ruídos, melhorar a infra-estrutura para recebimento de mercadorias e aumentar o número de vagas para carga e descarga. Os investimentos em estrutura são necessários também tanto por partes das empresas transportadoras quanto dos varejistas. Recomenda-se também acordos com associações de moradores ou representantes da comunidade para acertar o horário da entrega e evitar desgastes para a imagem da empresa, pois os problemas com ruídos parecem ser um fator crítico para a aceitação ou recusa das entregas noturnas, principalmente para os recebedores.

Dado que a maioria dos entrevistados, transportadores e varejistas, preferem continuar a executar descarregamentos noturnos, cabe ao poder público adequar a "Lei do Psiu", colocando limites mais altos de decibéis para o período noturno, tanto em zonas residenciais, quanto em zonas mistas. Além disso, o poder público deve melhorar as condições de iluminação pública, e fiscalizar as vagas de carga/descarga nas localidades próximas a bares e restaurantes no período noturno. O papel do poder público é fundamental para atender as reivindicações dos interessados, e garantir os efeitos positivos das entregas noturnas para o meio urbano. 
Adicionalmente, foram constatadas falhas estruturais relacionadas ao excesso de degraus, presença de porta estreita, calçadas em má conservação, falta de vagas para estacionar e carência de iluminação pública. A correção dessas falhas é importante para melhorar a eficiência do sistema de entregas urbanas.

As limitações desta pesquisa foram as seguintes: dificuldade para calcular o tamanho de uma amostra representativa dos motoristas; em algumas lojas, o recebimento feito até às $6 \mathrm{~h}$ foi considerado como noturno. Entretanto às $6 \mathrm{~h}$ as vias ainda não estão congestionadas, e por isso estas lojas compuseram a amostra. O questionário dos motoristas foi também aplicado por outros aplicadores, o que pode ter contribuído para um baixo número de respostas em algumas questões.

As entregas noturnas precisam ser estudadas em outros elos da cadeia de suprimentos, principalmente com relação às mudanças necessárias no centro de distribuição. Além disso, o ponto de vista de sujeitos envolvidos no âmbito executivo, os quais possuem uma visão mais precisa quanto à compensação dos custos que envolvem a implementação das entregas noturnas devem fazer parte da pesquisa. Como exemplo, citam-se os representantes dos embarcadores e operadores logísticos. A partir dessa investigação, por exemplo, poderia ser analisada se a eficiência das entregas noturnas evidenciadas no âmbito operacional pode compensar os custos adicionais decorrentes da adesão às entregas noturnas. 


\section{Referências}

AINGE, M. ABBOTT, P.; TREVELEN, C.; MORGAN, P.; NELSON, P.; WATTS, G.; STAIT, R. Alternative methods for the management of night-time freight noise in London, 2007 (Published Project Report).

ALLEN, J.; ANDERSON, S.; BROWNE, M.; JONES, P. A framework for considering policies for encourage sustainable urban freight traffic and goods/services flows London. University of Westminster, 2000. (Report 3: Making urban goods and services operations more sustainable: policy measures and company initiatives).

ALLEN, J.; BROWNE, M. (2010) Road Freight Transport and sustainability in Britain: 1984-2007. Green logistics project report. London, England.

ALMEIDA, A.; VIEIRA, J.; CAETANO, A.; ALMEIDA, A. Logística colaborativa: um estudo com fornecedores de supermercados de pequeno porte da zona da mata mineira. XXIX Encontro Nacional de Engenharia de Produção, 2009.

AMARAL, J. Trade-offs de custos logísticos. Dissertação (Mestrado) - Universidade de São Paulo, São Paulo, 2012.

AMBROSINI, C.; ROUTHIER, L. Objectives, results and methods of surveys carried out in the field urban freight transport: an international comparison. Transport Reviews. v. 24. p. 57-77, 2004.

ANDERSSON, D. Lessons from manufacturing industry. Urban freight for livable cities. How to deal with collaborations and trade-offs. The Volvo Research and Educational Foundations, VREF, 2012.

Associação Nacional de Transportes Públicos Avaliação do projeto-piloto de entregas noturnas no município de São Paulo. 2015. Disponível em: <http://filesserver.antp.org.br/_5dotSystem/download/dcmDocument/2016/02/24/EB80BD5B-7EED4537-A1A1-6B750B3F013F.pdf.> Acesso: 06/04/2016.

ARVIDSSON, N.; WOXENIUS, J.; LAMMGARD, C. Review of road hauliers' measures for increasing transport effiency and sustainability in urban freight distribution. Tranport Reviews: A Transnational Transdiciplinary Journal. v. 33, p. 107-127, 2013.

BALLANTYNE, E.; LINDHOLM, M.; WHITEING, A. A comparative study of urban freight transport planning: addressing stakeholders needs. Journal of Transport Geography. v.32. p. 93-101, 2013. 
BALLOU, R. Gerenciamento da cadeia de suprimentos. 5. ed. São Paulo: Bookman, 2006. BARCELONA MUNICIPALITY Quiet night deliveries, a complementary solution for the food sectors in Barcelona. OSMOSE (Open Source for Mobile and Sustainable City), 2006. BARBETTA, P. Estatística aplicada às ciências sociais. 4.ed. Santa Catarina: Editora da Universidade Federal de Santa Catarina, 2002.

BATTISTON, M.; CRUZ, R.; HOFFMAN, M. Condições de trabalho e saúde de motoristas de transporte coletivo urbano. Estudo Psicológico. n.3, v.11, 2006.

BERENDS, S.; LINDHOLM, M.; WOXENIUS, J. The impact of urban transport: a definition of sustainability from an actor's perspective. Transportation planning and technology. v.31, 2008.

BERGLUND, B.; LINDVALL, T. Community noises. Stockholm: Stockholm University and Karolinska Institute, 1995

BHAGAT, A.; SAPHORES, J.; JAYAKRISHNAN, R. Environmental and Health Impacts of Shifting Dryage Truck Operations to Off-Peak Hours: An Analysis of the PierPASS Program in Southern California. In: TRB CONFERENCE, 2014.

BRASIL, SÃO PAULO Lei No 16.050/2014. Texto base. Plano diretor estratégico, São Paulo, 2014.

BREWER, P.; SPEH, T. Using the balanced scorecard to measure supplu chain performance. Jounal of Business Logistics, v.21, p. 75-94, 2000.

BROWNE, M. Urban and logistics legacy of the London 2012 Olympic games. In: WORKSHOP CISLOG - URBAN FREIGHT SYSTEMS. São Paulo: Escola Politécnica, Universidade de São Paulo, 2013.

CAIXETA FILHO, J.; GAMEIRO, A. Administração de seguros no transporte de cargas. RAE - eletrônica FGV. v.1, n.1, 2002.

CAMBRIDGE SYSTEMATICS Institutional Arrangements for Freight Transportation Systems. Transportation Research Board. 2009. Disponível em:

http://onlinepubs.trb.org/onlinepubs/ncfrp/ncfrp_rpt_002.pdf. Acesso: 21/07/2016.

CAMPANELLI, P. Testing survey questions. International handbook of survey methodology. Utrecht University and Washington State University, 2008.

CARVALHO, C. Distribuição urbana de carga: um estudo com empresas que atuam na região metropolitana de São Paulo. Dissertação (Mestrado) - Universidade de São Paulo, São Paulo, 2014. 
CASTRO, J.; KUSE, H. Impacts of large truck restrictions in freight carrier operations in Metro Manila. Journal of the Eastern Asia Society for Transportation Studies. v.6, p. 2947-2962, 2005.

CERVERO, R. Como mudar este cenário? Caderno de mobilidade urbana. n.4, 2014.

Companhia de Engenharia de Tráfego (2014). Disponível em: <http://www.cetsp.com.br/consultas/>. Acesso em: set. 2014

Companhia de Engenharia de Tráfego. Abastecimento noturno em São Paulo. Implantação do projeto piloto. 2014. Disponível em: <http://www.cetsp.com.br/media/352699/entreganoturna.pdf>. Acesso: 15/08/2016.

Companhia de Engenharia de Tráfego. Locais com restrição ao caminhão. 2015. Disponível em: http://www.cetsp.com.br/consultas/caminhoes/locais-com-restricao-aocaminhao/zona-de-maxima-restricao-de-circulacao-zmrc.aspx. Acesso: 05/04/2015.

CHERRETT, T.; ALLEN, J.; MCLEOD, F.; MAYNARD, S.; HICKFORD, A.; BROWNE, M. Understanding urban freight activity - key issues for freight planning. Journal Transport Geography. v. 24, p. 22-32, 2012.

CHURCHMAN, C. Introdução à teoria dos sistemas. $2^{\text {a }}$ Ed. Rio de Janeiro: Editora Vozes, 1972.

CONSENZA, C.; FOWLER, F. Writing effective questions. International handbook of survey methodology. Utrecht University and Washington State University, 2008.

COSTA, A. Introdução à nova ordem mundial. 2. ed. São Paulo: Vide Editorial, 2015.

COSTA NETO, P. Estatística. São Paulo: Editora Edgard Blücher

CRAINIC, T.; RICCIARDI, N.; STORCHI, G. Advanced freight transportation systems for congestion urban areas. Transport Research Part C. v.12. p. 119-137, 2004.

CUNHA, C.; YOHIZAKI, H. Carga pesada. Caderno de mobilidade urbana. n.4, 2014.

CUI, J.; DODSON, J.; \& PETER V. HALL Planning for urban freight transport: an overview. Transport Reviews. v.5, p. 583-598, 2015.

DABLANC, L. Goods transport in large European cities: difficult to organize, difficult to modernize. Transport Research Part A: Policy Practice. v.41, p. 280-285, 2007.

DABLANC, L.; MONTENON, A. Impacts of environmental access restrictions on freight delivery activities, the example of low emissions zone in Europe. Transportation Research Boarder 94 ${ }^{\text {rd }}$ Annual Meeting. Washington, 2015. 
DIZAIN, D. Addressing the urban freight issue in France. Urban freight for livable cities. How to deal with collaborations and trade-offs. The Volvo Research and Educational Foundations, VREF, 2012.

DOUGLAS, C.; LAGRANGE, A.; MABELIS, J. Out-of-hours Deliveries in Central London. Travel \& Transport Research. v.2, 2008.

DUTRA, N. O enfoque de "city logistics" na distribuição urbana de encomendas. Tese (Doutorado) - Universidade Federal de Santa Catatina, Florianópolis, 2004.

ECONOMICS ONLINE Types of Market Failures, 2012. Disponível em: <http://www.economicsonline.co.uk/Market_failures/Types_of_market_failure.html.>. Acesso: 26/06/2015.

ELTIS THE URBAN MOBILITY OBSERVATORY Night Delivery in Barcelona. Cases studies. 2014. Disponível em: http://www.eltis.org/discover/case-studies/night-deliverybarcelona-spain. Acesso: 01/04/2015.

Empresas de Transporte e Trânsito de Belo Horizonte Política de Logística Urbana. 2016. Disponível em: <http://www.bhtrans.pbh.gov.br/portal/page/portal/portalpublico/Temas/Automovel/LOGIS TICAURBANA/ConsultaPublicaLogisticaUrbanaBH/OPERACAO\%20DE\%20CARGA\%2 0E\%20DESCARGA.> Acesso: 09/11/2016

FÁVERO, L.; BELFIORE, P.; SILVA, F.; CHAN, B. Análise de dados. Modelagem multivariada para tomada de decisões. Editora Campus: Rio de Janeiro, 2009.

FERREIRA, J. Globalização e urbanização subdesenvolvida. São Paulo em perspectiva, v.14, n.4, 2000.

FILHO, A. Uma contribuição ao estudo de indicadores da qualidade do serviço padrão de transporte de carga expressa no âmbito nacional. Dissertação (Mestrado) Universidade Federal do Rio de Janeiro, Rio de Janeiro, 2006.

FINLAY, H. Noises abetement and night deliveries. Thesis - Dublin Institute of Technology, Dublin, 2008.

FREEMAN, E. The politics of Stakeholders Theory. Business Ethics Quartely. v.4, p. 409-421, 1994.

GELINO, K.; KRASS, C.; OLDS, J.; SANDERCOOK, M. (2012) Why can't we befriends? Reducing conflicts between bicycles and trucks. Department of Urban design and planning. University of Washington. 
GEROLIMINIS, N.; DAGANZO, C. A review of green logistics schemes used in cities around the world. U.C Berkeley Center for Future Urban Transport. Volvo Center of Excelence, 2005.

GIACON, J. Conceitos em logística e supply chain. São Paulo, Fundação Vanzolini. Notas de aula, 2015.

GREENBERG, J. Administração do Estresse. 6 ed. São Paulo: Manole, 2002.

HENDY, P. How the Olympics changed freight deliveries in London. Urban freight for livable cities. How to deal with collaborations and trade-offs. The Volvo Research and Educational Foundations, VREF, 2012.

HOGAN, D.; CUNHA, J.; BAENINGER, R.; CARMO, R.; Migração e ambiente. Aspectos relevantes da dinâmica recente. Campinas: NEPO/UNICAMP, 2000.

HOLGUÍN-VERAS, J. Revealed preferences analysis of commercial vehicle choice process. Journal of transportation engineering. v.128, p. 336-346, 2002.

HOLGUÍN-VERAS, J.; XU, N.; JONG, G.; MAURER, H. An experimental economics investigation of shipper-carrier interactions on the choice of mode and shipment size in freight transport. Network and Spatial Economics. v.11, 2011.

HOLGUÍN-VERAS, J.; POLINEMI, J.; CRUZ, B.; XU, N.; LIST, G.; NORDSTROM, $\mathrm{J}$;

HADDOCK, J. Off-Peak freight deliveries: challenges and stakeholders perceptions. Transport Research Records. p. 42-48, 2014.

HOLGUÍN-VERAS, J.; WANG, C.; BROWNE, M.; HODGE, S.; WOJTOWICZ, J. The New York City off-hour delivery project: lessons for city logistics. $8^{\text {th }}$ International Conference on City Logistics. p. 36-48, 2014.

HOLGUÍN-VERAS, J; HODGE, S. Lessons from the off-hour delivery program in New York City. In: Webinar Peer to Peer Exchange Program, 2013. Disponível em: coesufs.org/wordpress/peer-to-peer-exchange-program/webinar01/. Acesso: 21/05/2014.

HOLGUÍN-VERAS, J., OZBAY, K., KORNHAUSER, A., BROM, M. A., IYER, S., YUSHIMITO, W. F., UKKUSURI, S., ALLEN, B.; SILAS, M. A. Overall impacts of off-hour delivery programs in the New York City metropolitan area. Transportation Research Record. p. 68-76, 2011. 
HOLGUÍN-VERAS, J.; OZBAT, K.; KORNHAUSER, A.; SHORRIS, A.; UKKUSURI, S. Integrative freight demand management in the New York City metropolitan area. United States Department of Transportation, 2010 (Final Report).

HOLGUÍN-VERAS, J.; MARQUIS, R.; BROM, M. Economics impacts of staffed and unassisted off-hour deliveries in New York City. Procedia and Behavioral Sciences. v.39, p. 34-46, 2012.

HOLGUÍN-VERAS, J.; SILAS, M.; POLIMENI, J.; CRUZ, B. An investigation on the effectiveness of joint receiver-carrier policies to increase truck traffic in the off-peak hours: Part I: The behaviors of receivers. Networks and Spatial Economics. p. 277-295, 2007.

KACHE, F.; SEURING, S. Linking collaboration and integration to risk and performance in supply chains via a review of literature. Supply Chain Management: An International Journal. v. 19, p.664-682, 2014.

INSTITUTO BRASILEIRO DE EXECUTIVOS DE VAREJO E MERCADO DE CONSUMO. Ranking IBEVAR. 120 maiores empresas do varejo, 2013. Disponível em: <www.pwc.com.br/pt/publicacoes/setores-atividade/assets/produtos-consumovarejo/ranking-ibevar-2013.pdf.> Acesso: 25/04/2016.

IYLER, S. Estimating Traffic Impacts of an Off-hour Delivery Program Using a Regional Planning Model. Graduate Thesis - The State University of New Jersey, New Jersey, 2010. LAMBERT, D.; POHLEN, T. Supply chain metrics. The International Journal of Logistics Management. v. 12, p. 1-19, 2001.

LEFEBVRE, H. O direito à cidade. 5.ed. São Paulo: Centauro Editora, 2011.

LIMA JUNIOR, O. Logística urbana se resolve com tecnologia e governança. Revista Mundo Logística. Ed. 36, 2013.

LIMA JUNIOR, O. Um framework de indicadores de desempenho empresariais aplicados à governança de plataformas logísticas. Espacios. v. 34, 2013.

LINDHOLM, M.; BROWNE, M. Local authority cooperation with urban freight stakeholders: a comparison of partnership approaches. European Journal of Transport and Infrastructure Research. v.13, p. 20-38, 2013.

LIU, M.; ZHAO, J. Research the Key Logistics Capability on Embedding Regional Trade Service Profit Chain. International Conference of Logistics Engineering and Management: Logistics for Sustained Economic Development. p. 4051-4057, 2010. LOGWEB JORNAL Ford cria sistema de entregas noturnas. Edição 21, 2003. 
LJUBICIC, H.; PAVLOVIC, J. Urban logistics system and night goods delivery. $2^{\text {nd }}$ Logistics International Conference. Belgrade, 2015.

MARTE, C.; YOSHIOKA, L.; MEDEIROS, J.; PERON, L.; SANTOS, A.; MARQUEZ, J. Sistemas Inteligentes de Transporte aplicados em corredores BRT: casos brasileiros. XVIII ANPET, 2014.

MCLEOD, F.; CHERRET, T. Modelling impacts of shared freight-public transport lanes in urban centres. Research Gates. University of Southampton, 2015.

MERCADONA Mercadona Environmental Policy. The urban mobility observatory Eltis, 2010.

MEYER, R. O desafio do deslocamento. Caderno de mobilidade urbana. n.4, 2014.

MINGOTI, S. A análise de dados multivariada através de métodos de estatística multivariada: uma abordagem aplicada. Belo Horizonte: Editora UFMG, 2005.

MOBILIZE A cidade sem automóvel - Parte 1: a cultura do automóvel. Mobilidade urbana sustentável. 2011. Disponível em: http://www.mobilize.org.br/noticias/791/a- cidade-semcatracas--parte-i-cultura-do-automovel.html. Acesso: 10/7/2015.

MOREIRA, J.; CARVALHO, J. Investigando o roubo de carga nas rodovias a partir da percepção dos atores envolvidos com o problema. Gestão \& regionalidade. n. 79, v.27, 2011. MOURA, L. Avaliação do impacto do sistema de rastreamento de veículos na logística. Dissertação (Mestrado) - Pontifícia Universidade Católica, Rio de Janeiro, 2004.

MUNDO LOGÍSTICA Roubo de cargas: Brasil é país de alto risco, 2015. Disponível em: <http://www.mundologistica.com.br/portal/noticia.jsp?id=2429>. Acesso: 31 ago. 2015.

MUNUZURI, J.; LARRANETA, J.; ONIEVA, L.; CORTES, P. Solutions applicable by local administrations for urban logistics improvement. Cities. v.22, p.15-28.

NEW YORK CITY DEPARTMENT OF TRANSPORTATION (NYCDOT) AND RENSSELAER POLYTECHNIC INSTITUTE (RPI). Noise Mitigation Strategies: Educational Material for the Participants of the Launch Phase of the New York City Off Hours Delivery Project. 2012.

NEUFVILLE, R.; STAFFORD, J. Systems analysis for engineers and managers. McGraw-Hill, 1971.

NICHES (New and Innovative Concepts for Helping European Transport Sustainability) Inner-city night delivery. European Cities and Regions Networking for Innovative Transport Solutions. Policy Notes, 2007. 
NOEL, E.; CRIMMINS, S.; MYERS, N.; ROSS, P. A Survey of Off-Hours Delivery. ITE Journal. p. 18-23, 1980.

OLIVEIRA, L.; BRAGA, A.; ABREU, B. Relevant Atributes in overnight goods delivery: researchers', trasnporters' and retaliers'preference in urban distribution. $12^{\mathrm{a}}$ WCTR. Lisboa, 2014.

ONTARIO MINISTRY OF TRANSPORTATION Off Peak Deliveries, 2013. Disponível em: https://www.peelregion.ca/pw/transportation/goodsmovement/art/2013-11/MTO-

PGMTF\%20Presentation_Nov\%201\%202013_DRAFT\%20CONFIDENTIAL.pdf. Acesso: $11 / 08 / 2015$.

ORTUZAR, J.; WILLUMSEN, L. (2011) Modelling Transport. 4ªEd. United Kingdom.

PAS, E. The urban transportation planning process. The geography of urban transportation. Duke University, 2004.

PIER PASS PROGRAM Off-Peak Frequently Asked Questions, 2015. Disponível em: <http://www.pierpass.org/offpeak-information/offpeak-frequently-asked-questions>. Acesso: $7 / 10 / 2015$.

PORTER, C.; HUSSEY, L.; KALL, D.; DEMPSTER, J. Assessing and comparing environmental performance of maj or transitis investiments. Cambridge, Inc., 2012 (Final Report for Transitie Cooperative Research Program).

QUAK, H. Reducing the load with urban consolidation centres. Urban freight for livable cities. How to deal with collaborations and trade-offs. The Volvo Research and Educational Foundations, VREF, 2012.

QUERESHI, A.; TANIGUCHI, E.; YAMADA, T.Exact solution for the vehicle routing problem with semi soft time windows and its application. The sixth international conference on City Logistics. v.2, p. 5931-5943, 2010.

QUIROGA, C. Performance measures and data requirements for congestion management systems. Transportation Research Part C. v. 8, p. 287-306, 2000.

RACHID, L.; SAMIMI, A. Relationship between economic and transportation infrastructure indicators and freight productivity growth. Journal of Urban Planning and Development. v. 138, p. 254-262, 2012.

RIBEIRO, F. O roubo de carga nas rodovias do Estado de São Paulo - Trabalho de Conclusão de Curso. Pontifícia Universidade Católica, Curitiba, 2009. 
RUÍDO, OMS E LEGISLAÇÃO - Blog Silêncio Negado. Disponível em: <http://silencionegado.blogspot.com.br/p/perturbacao-provocada-pelo-ruido.html.> Acesso: $10 / 05 / 2015$.

RUSSO, F.; COMI, A. Measures for sustainable freight transport at urban scale: Expected goals and tested results in Europe. Journal of Urban Planning and Development. v. 137. p.142-152, 2011.

SAÉZ, L.; PERIAÑEZ, I. Benchmarking urban competitiveness in Europe to attract investment. Cities. v.48, p. 76-85, 2015.

SANCHES JUNIOR, P. Logística de carga urbana: uma análise da realidade brasileira. Tese (Doutorado) - Universidade Estadual de Campinas, Campinas, 2008.

SALDIVA, P. Os efeitos sobre a saúde. Caderno de mobilidade urbana. n.4, 2014.

SANTOS, E. A iluminação pública como elemento de composição da paisagem urbana. Dissertação (Mestrado) - Universidade Federal do Paraná, Paraná, 2005.

SANTOS, M. Por uma outra globalização - do pensamento único à consciência universal. Editora Record: São Paulo, 2000.

SARTORIO, S. Aplicações de técnica de análises multivariada em experimentos agropecuários usando o software R. Dissertação (Mestrado) - Escola Superior de Agricultura "Luís de Queirós”, Universidade de São Paulo, Piracicaba, 2008.

SHIRO, L. Implantação de um sistema de indicadores de desempenho para operação logística de uma empresa de comércio eletrônico. Trabalho de formatura - Escola Politécnica, Universidade de São Paulo, São Paulo, 2011.

SILVA, A. Fatores de estresse para o motorista e o usuário do transporte coletivo do distrito federal e a percepção de um em relação ao outro. Dissertação (Mestrado) Universidade de Brasília, Brasília, 2014.

SMALL, K.; DENDER, K. Long run trends in transport demand, fuel price and implications of the oil outlook for transport policy. International Transport Forum. p. 7-16, 2007.

SOUSA, R. Gestão de segurança pública: em busca de um modelo para a prevenção da violência. III Jornada Internacional de políticas públicas, questão social e desenvolvimento no século XXI. São Luís, 2007.

STATHOPOULOS, A.; VALERI, E.; MARCUCCI, E. Urban freight policy innovation for Rome: a stakeholder perspective. City Distribution and Urban Freight Transport. p. 1$18,2011$. 
SUSILAWATI, S.; TAYLOR, M.; SOMENAHALLI, S. Distribution of travel time on urban roads. Jounal of Advanced Transportation. v. 47, p. 720-733, 2011.

TANIGUCHI, E.; THOMPSON, R. Modelling city logistics. Transportation Research Record. 1790, p. 45-51, 2002.

TANIGUCHI, E.; THOMPSON, R.; YAMADA, T.; DUIN, R. City Logistics: network modeling and intelligent transport systems. Oxford, 2011.

TANIGUCHI, E.; IMANISHI, Y.; BARBER, T.; JAMES, J.; DEBAUCHE, W. Public sector governance to implement freight vehicle transport management. $8^{\text {th }}$ International Conference on City Logistics. v.125. p. 345-357, 2014.

UNITED NATIONS REGIONAL INFORMATIONS CENTRE Relatório da ONU mostra população mundial cada vez mais urbanizada, mais de metade vive em zonas urbanizadas ao que se podem juntar 2,5 mil milhões em 2050. Disponível em: $<$ http://www.unric.org/pt/actualidade/31537-relatorio-da-onu-mostra-populacao-mundial-

cada- vez-mais-urbanizada-mais-de-metade-vive-em-zonas-urbanizadas-ao-que-se-podemjuntar- 25-mil-milhoes-em-2050.> Acesso em: 07. out. 2015

VASCONCELLOS, E. Mobilidade urbana e cidadania. Rio de Janeiro: SENAC Editoras, 2012.

VIEIRA, J. Avaliação do estado de colaboração logística entre indústria de bens de consumo e redes de varejo supermercadista. Tese (Doutorado) - Universidade de São Paulo, São Paulo, 2006.

VIERA, J.; CARVALHO, C.; FRANSOO, J. Freight distribution in megacities: perspectives of shippers, logistics services providers and carriers. Journal of Geography Transport. v. 46, p. 46-54, 2015.

VIEIRA, S. Como elaborar questionários. Editora Atlas, 2009.

WHIPPLE J.; LYNCH, D.; NYAGA, G. A Buyer's Perspective on Collaborative Versus Transactional Relationships. Industrial Marketing Management. v.39, p. 507-518, 2010.

WITTLOV, A. Introdution urban freight transport: challenges and opportunities. Urban freight for livable cities. How to deal with collaborations and trade-offs. The Volvo Research and Educational Foundations, VREF, 2012.

YANNIS, G.; GOLIAS, J.; ANTONIOU, C. Effects of urban delivery restrictions on traffic movements. Transportation Planning and Technology. v. 29, p. 295-311, 2006. 
ZAMBUZI, N. Metodologia para a avaliação de medidas voltadas à distribuição urbana de carga através do uso da microssimulação de tráfego. Tese (Doutorado) - Escola Politécnica, Universidade de São Paulo, São Paulo, 2015. 
QUESTIONÁRIO DE PESQUISA SOBRE ENTREGAS NOTURNAS - MOTORISTAS

\section{BLOCO 1- CARACTERIZAÇÃO DO ENTREVISTADO}

\section{Nome:}

Empresa:

Tempo de trabalho na profissão:

Tipo de contrato:

BLOCO 2 - SOBRE O TRABALHO E AS ENTREGAS

1. Você prefere trabalhar em qual horário?

$\square$ Dia (05hs - 21hs) $\square$ Noite (21hs - 05hs) $\square$ Sem preferências

2. Você se sente mais estressado trabalhando de dia ou de noite?

Dia (05hs - 21hs) $\square$ Noite (21hs - 05hs) $\square$ Não tenho preferência

3. Considerando uma mesma rota, quantas horas dirige?

Dia $(05 \mathrm{~h} 00-21 \mathrm{~h} 00)$ Noite $(21 \mathrm{~h} 00-05 \mathrm{~h} 00)$

4. Considerando uma mesma loja, qual o tempo médio gasto para achar uma vaga de estacionamento em cada parada (em minutos estimados)?

Dia $(05 h 00-21 h 00)$ Noite $(21 \mathrm{~h} 00-05 \mathrm{~h} 00)$

5. Os veículos de carga são mais pontuais em qual período?

Dia (05hs - 21hs) $\square$ Noite (21hs - 05hs)

6. Quais tipos de multas mais ocorrem?

Estacionamento em fila dupla $\square$ Vaga proibida $\square$ Restrição de circulação

\section{BLOCO 3 - AVALIAÇÃO DAS AÇÕES DO PODER PÚBLICO}

7. Dê sua opinião sobre as condições de iluminação pública no entorno da loja. Marque um X para uma das opções abaixo.

\begin{tabular}{|c|c|c|c|c|}
\hline Muito ruim & Ruim & Regular & Boa & Muito Boa \\
\hline & & & & \\
\hline
\end{tabular}


8. Dê a sua opinião sobre a importância para o poder público executar as seguintes ações.

\begin{tabular}{|l|l|l|l|}
\hline & $\begin{array}{l}\text { Pouco } \\
\text { importante }\end{array}$ & $\begin{array}{l}\text { Razoavelmente } \\
\text { importante }\end{array}$ & $\begin{array}{l}\text { Muito } \\
\text { importante }\end{array}$ \\
\hline $\begin{array}{l}\text { Demarcação de vagas de carga e } \\
\text { descarga }\end{array}$ & & & \\
\hline Melhoria de calçadas & & & \\
\hline
\end{tabular}

\section{BLOCO 4 - ESTRUTURA DE RECEBIMENTO NAS LOJAS}

9. Qual, na sua opinião, é a melhor forma de ENTREGA NOTURNA?

$\square$ Assistida (com auxílio de funcionários da loja) $\square$ Não - assistida (sem auxílio de funcionários da loja)

10. Restrições que dificultam a entrega das mercadorias. Marque a opção apresenta MAIOR dificuldade.

Degraus

$\square$ Porta estreita

$\square$ Fila de caminhões para o recebimento de mercadorias

$\square$ Dificuldade em acessar o local de entrega por questões administrativas do estabelecimento, shopping ou condomínio

Outro. Especifique

\section{BLOCO 5 - IDENTIFICAÇÃO DE PROBLEMAS PARA AS ENTREGAS NOTURNAS}

11. Há segurança para receber a noite? $\square \operatorname{Sim} \square$ Não

12. Há problemas quanto aos ruídos emitidos durante as entregas noturnas? $\square \operatorname{Sim} \quad \square$ Não

Comentários gerais.

OBRIGADO PELA COLABORAÇÃO 


\section{APÊNDICE B - QUESTIONÁRIO DOS RECEBEDORES}

\section{QUESTIONÁRIO DE PESQUISA SOBRE ENTREGAS NOTURNAS - VAREJISTAS \\ BLOCO 1- CARACTERIZAÇÃO DO ENTREVISTADO E DA EMPRESA}

Nome do respondente:

Empresa:

E-mail:

Cargo:

Tempo de experiência no cargo atual:

Setor de atuação:

Número de funcionários:

Quantos funcionários são designados para receber as mercadorias:

Horário de atendimento ao cliente:

\section{BLOCO 2 - SOBRE A ORGANIZAÇÃO DA LOJA}

1. Qual o horário de maior movimentação de clientes na loja? Marque um X no espaço em branco abaixo

\begin{tabular}{|l|l|l|l|c|}
\hline Manhã & Horário do almoço & Tarde & Noite & Madrugada \\
\hline & & & & \\
\hline
\end{tabular}

2. Qual o melhor horário para alocar as mercadorias na gôndola? Marque um X no espaço em branco abaixo

\begin{tabular}{|l|l|l|l|l|}
\hline Manhã & Horário do almoço & Tarde & Noite & Madrugada \\
\hline & & & & \\
\hline
\end{tabular}

3. Qual o horário atual de recebimento de mercadorias? Marque um X na reposta certa.

$\square$ Diurno $(5 \mathrm{~h}-21 \mathrm{~h}) \quad \square$ Noturno $(21 \mathrm{~h}-5 \mathrm{~h})$

4. Doca interna: $\square$ Sim $\square$ Não

\section{BLOCO 3 - AVALIAÇÃO DAS AÇÕES DO PODER PÚBLICO}

5. Dê sua opinião sobre as condições de iluminação pública no entorno da loja. Marque um X abaixo da melhor opção

\begin{tabular}{|l|l|l|l|l|}
\hline Muito ruim & Ruim & Regular & Boa & Muito Boa \\
\hline & & & & \\
\hline
\end{tabular}

6. Dê a sua opinião sobre a importância para o poder público executar as seguintes ações.

\begin{tabular}{|l|c}
\hline Pouco & Razoavelmente \\
importante & importante
\end{tabular}


Demarcação de vagas de carga e descarga

Melhoria de calçadas

\section{BLOCO 4 - ESTRUTURA DE RECEBIMENTO}

7. Qual, na sua opinião, é a melhor forma de recebimento noturno?

$\square$ Assistida (com auxílio de funcionários da loja) $\square$ Não - assistida (sem auxílio de funcionários da loja)

8. Restrições que dificultam a entrega das mercadorias. Marque a que apresenta a maior dificuldade

$\square$ Degraus

Porta estreita

Calçada em má conservação

Não há vagas para parar (proximidade com outros comércios)

Fila de caminhões para o recebimento de mercadorias

$\square$ Dificuldade em acessar o local de entrega por questões administrativas do estabelecimento, shopping ou condomínio

Outro. Especifique

\section{BLOCO 5 - DESEMPENHO LOGÍSTICO DA EMPRESA}

8. Com relação aos seguintes aspectos, em qual dos períodos diurno ( $21 \mathrm{~h}-5 \mathrm{~h})$ e noturno (5h-21h), o desempenho do entregador é melhor?

\begin{tabular}{|l|l|l|}
\hline & Dia $(5 \mathrm{~h}-21 \mathrm{~h})$ & Noite $(21 \mathrm{~h}-5 \mathrm{~h})$ \\
\hline Pontualidade das entregas recebidas & & \\
\hline Agilidade para conferir e armazenar & & \\
\hline Qualidade de atendimento ao cliente & & \\
\hline Preferência do estoquista & & \\
\hline
\end{tabular}

9. De maneira geral, na sua opinião é melhor receber as mercadorias de dia ou noite?

Dia $(5 \mathrm{~h}-21 \mathrm{~h}) \square$ Noite $(21 \mathrm{~h}-5 \mathrm{~h})$

\section{BLOCO 6 - IDENTIFICAÇÃO DE PROBLEMAS PARA AS ENTREGAS NOTURNAS}

10. Há segurança para receber a noite? $\square \operatorname{Sim} \square$ Não

1q1. Há problemas quanto aos ruídos emitidos durante as entregas noturnas $\square$ Sim $\square$ Não

Comentários gerais.

OBRIGADO PELA COLABORAÇÃO! 